\title{
Leveraging an Open Science Drug Discovery Model to Develop CNS- Penetrant ALK2 Inhibitors for the Treatment of Diffuse Intrinsic Pontine Glioma
}

David Smil,* Jong Fu Wong, Eleanor P. Williams, Roslin J. Adamson, Alison Howarth, David A. McLeod, Ahmed Mamai, Soyoung Kim, Brian J. Wilson, Taira Kiyota, Ahmed Aman, Julie Owen, Gennady Poda, Kurumi Y. Horiuchi, Ekaterina Kuznetsova, Haiching Ma, J. Nicole Hamblin, Sue Cramp, Owen G. Roberts, Aled M. Edwards, David Uehling, Rima Al-awar, Alex N. Bullock, Jeff A. O’Meara, and Methvin B. Isaac*

Cite This: J. Med. Chem. 2020, 63, 10061-10085

Read Online

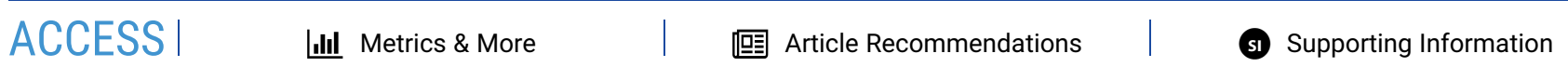
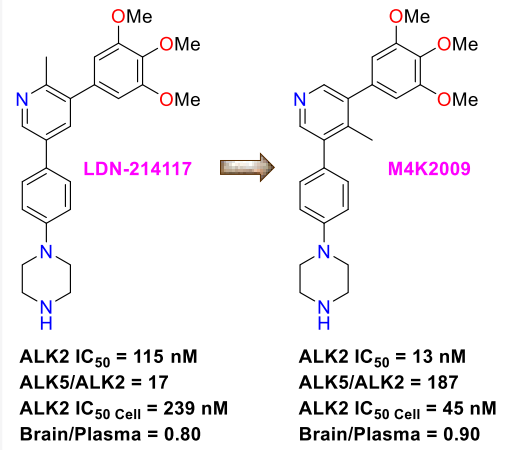

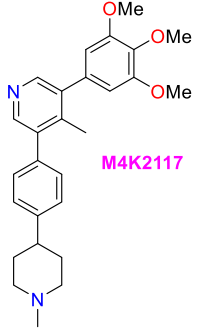

ALK2 IC ${ }_{50}=7 \mathrm{nM}$ ALK5/ALK2 $=714$ ALK2 IC $_{50 \text { cell }}=29 \mathrm{nM}$ Brain $/$ Plasma $=0.82$

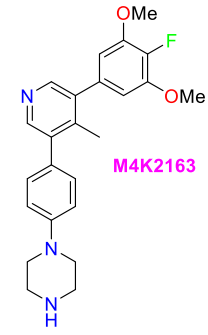

ALK2 IC ${ }_{50}=19 \mathrm{nM}$

ALK5/ALK2 $=116$

ALK2 IC 50 Cell $=98 \mathrm{nM}$

Brain/Plasma $=1.41$

ABSTRACT: There are currently no effective chemotherapeutic drugs approved for the treatment of diffuse intrinsic pontine glioma (DIPG), an aggressive pediatric cancer resident in the pons region of the brainstem. Radiation therapy is beneficial but not curative, with the condition being uniformly fatal. Analysis of the genomic landscape surrounding DIPG has revealed that activin receptor-like kinase-2 (ALK2) constitutes a potential target for therapeutic intervention given its dysregulation in the disease. We adopted an open science approach to develop a series of potent, selective, orally bioavailable, and brain-penetrant ALK2 inhibitors based on the lead compound LDN-214117. Modest structural changes to the C-3, C-4, and C-5 position substituents of the core pyridine ring afforded compounds M4K2009, M4K2117, and M4K2163, each with a superior potency, selectivity, and/or bloodbrain barrier (BBB) penetration profile. Robust in vivo pharmacokinetic (PK) properties and tolerability mark these inhibitors as advanced preclinical compounds suitable for further development and evaluation in orthotopic models of DIPG.

\section{INTRODUCTION}

Pediatric central nervous system (CNS) tumors constitute a heterogeneous group of diseases, and patient survival rates vary greatly among tumor subtypes. ${ }^{1}$ Diffuse intrinsic pontine glioma (DIPG), a grade IV tumor originating in glial tissue of the pons and typically affecting children between 5 and 7 years of age, ${ }^{2,3}$ is highly infiltrative with a 5-year relative survival rate of less than $1 \%$. While accounting for $10 \%$ of all pediatric brain tumors, a median survival of just 9-12 months means that the prognosis for children with DIPG is particularly poor relative to those with other brainstem cancers. ${ }^{5}$ Given that the pons contains cranial nerve nuclei and nuclei critical for life-sustaining functions such as respiration and sleep, damage by the tumor or treatment has potentially severe repercussions. ${ }^{6}$ Sensitivity of the affected pons region renders it unsuitable for surgical resection, so the current standard of care is limited to focal radiation therapy providing only limited and temporary benefit for patient survival.? Chemotherapeutic agents have also met with little success in prolonging patient survival, ${ }^{4,6}$ in part because CNS drug exposure is limited by the endothelial tight junctions and elevated expression levels of efflux transporters at the bloodbrain barrier (BBB), making it difficult to reach therapeutically relevant drug concentrations at lesion sites. ${ }^{8}$ A number of brain-

Received: July 10, 2020

Published: August 11, 2020 
A

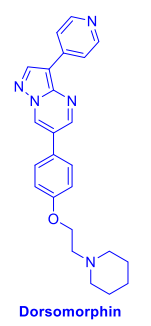

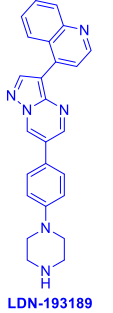<smiles>C1CCC(COCCOCCNC2CCCC2)CC1</smiles>

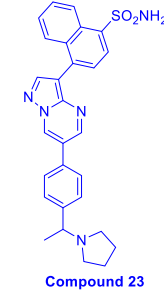<smiles>CC1CCCC1C1CCC1C1C(C)CCC1C</smiles>
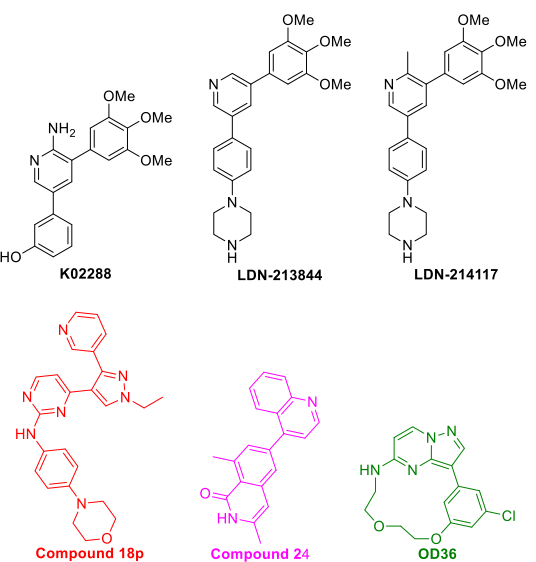

B

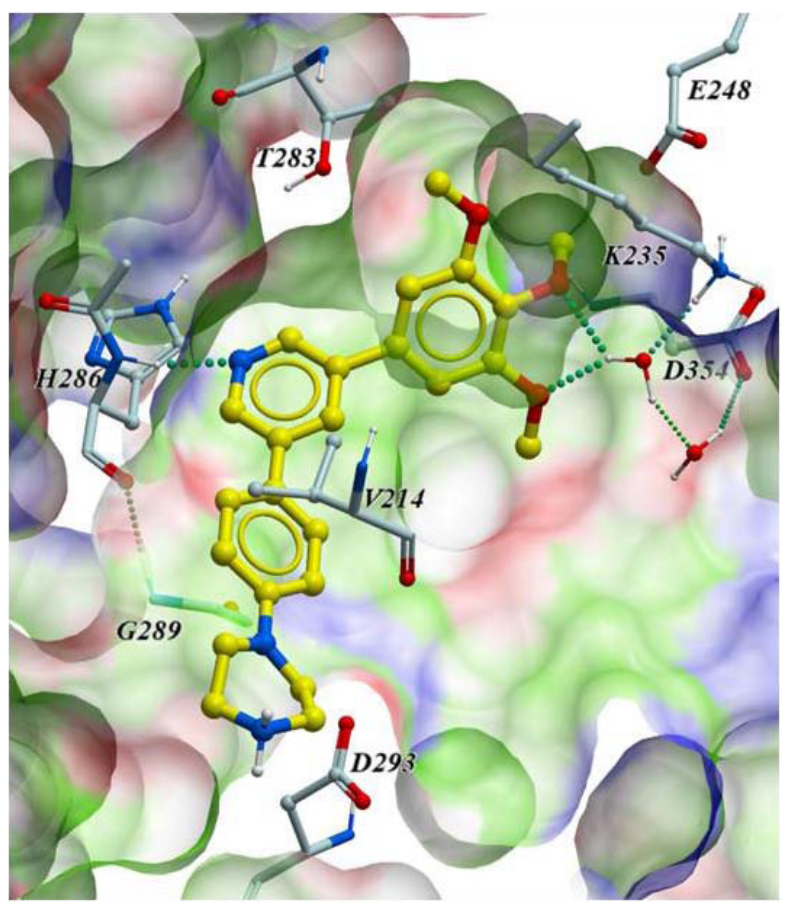

Figure 1. (A) Reported ALK2 inhibitors based on pyrazolo[1,5-a]pyrimidine (blue), 3,5-diphenylpyridine (black), bis-heteroaryl pyrazole (red), quinazolinone (magenta), and macrocyclic (green) scaffolds. (B) Cocrystal structure of prototypic 3,5-diphenylpyridine inhibitor LDN-213844 (yellow) with ALK2 (PDB code 4BGG). ${ }^{37}$

penetrant chemotherapeutic agents such as temozolomide and vincristine have been explored as complements to radiotherapy, but no significant improvement in outcomes has been observed. ${ }^{9,10}$

The advent of modern stereotactic procedures to safely biopsy DIPG tumors ${ }^{11}$ has opened new avenues for molecular characterization and overturned old orthodoxies relating to the classification and treatment of both adult and childhood gliomas as similar tumors. ${ }^{12}$ In contrast to the $I D H 1 / 2, B R A F$, or FGFR oncogenic driver mutations found in adult gliomas, mutations in histone and developmental signaling proteins are characteristic of DIPG. ${ }^{13,14}$ Somatic missense mutations in the bone morphogenetic protein (BMP) type I receptor ACVRI gene encoding activin receptor-like kinase-2 (ALK2), one of the seven (ALK1-7) type I receptors in the transforming growth factor $\beta(\mathrm{TGF} \beta) / \mathrm{BMP}$ signaling pathway, have been reported in approximately $33 \%$ of children with DIPG. ${ }^{2,3}$ The ACVR1 gene, widely expressed in a variety of tissues including bone, cartilage, heart, CNS, and the reproductive system, is located in chromosome 2q23-q24 and encodes for the 509 amino acid protein. ${ }^{15}$ Although rare in other human cancers, similar ACVR1 mutations are found in individuals with fibrodysplasia ossificans progressiva (FOP), a monogenic developmental disorder whose primary features are skeletal abnormalities and heterotopic ossification. $^{16-18}$ In DIPG, mutant ACVR1 is ubiquitous throughout the tumors and strongly associated with $\mathrm{K} 27 \mathrm{M}$ mutations in HIST1H3B, suggesting a partnership with H3K27M mutations during clonal evolution. ${ }^{19}$

Comprising an extracellular ligand binding domain and an intracellular serine/threonine (Ser/Thr) kinase domain, ALK2 functions as a transmembrane receptor. ${ }^{20}$ When BMP ligands bind to a complex of ALK2 and type II BMP receptors, the resultant activation of ALK2 by transphosphorylation of its juxtamembrane glycine-serine (GS)-rich domain promotes the recruitment and phosphorylation of downstream transcription factors SMAD1/5/8 by ALK2 and subsequent induction of BMP-response genes such as ID1-3 (known mediators of gliomagenesis). ${ }^{21-23}$ Heterozygous somatic nonsynonymous missense gain-of-function mutations present exclusively in the cytoplasmic GS (20\% R206H and 2\% Q207E) and Ser/Thr kinase domains (13\% R258G, 24\% G328E, 28\% G328V, 4\% G328W, and $9 \% \mathrm{G} 356 \mathrm{D})^{2}$ of ALK2 not only result in hypersensitivity to canonical BMP ligands but also induce responsiveness to activin ligands. ${ }^{24,25}$ Each $A C V R 1$ mutant was found to increase basal canonical BMP pathway signaling when overexpressed in cultured mouse primary astrocytes, suggesting a role for these mutations during neurodevelopment. ${ }^{2}$ Although mutant ALK2 alone is not sufficient to drive tumor formation (i.e., FOP patients with somatic ALK2 mutations do not develop DIPG) and the mechanistic role of ALK2 in DIPG pathogenesis has not yet been fully elucidated, ${ }^{2,26}$ significant cooperation between mutant ALK2 and the oncohistone H3.1K27M has been demonstrated in neurospheres, with a strong influence of ALK2 on gliomagenesis (initiation, proliferation, and survival)

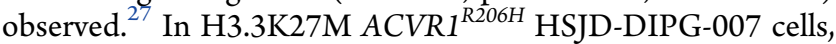
shRNA knockdown of ACVR1 not only caused reduction in cell viability but also resulted in increased apoptotic cell death. While mutated histone $\mathrm{H} 3$ is not directly druggable, ALK2 is a classical protein kinase constituting a suitable target for a drug discovery program.

Following the discovery that an adenosine monophosphate (AMP)-activated kinase inhibitor, Dorsomorphin, could block BMP signaling through SMAD1/5/8 phosphorylation, ${ }^{28}$ a number of related inhibitors centered around the pyrazolo$[1,5-a]$ pyrimidine chemotype were reported (Figure 1A). ${ }^{29}$ Inhibitors of ALK2 such as LDN-193189 $9^{30}$ and LDN$\mathbf{2 1 2 8 5 4 ^ { 3 1 , 3 2 }}$ showed efficacy in FOP mouse models $^{33}$ although their activity against a number of kinase off-targets ${ }^{34}$ and doselimiting toxicity (a $10 \%$ body weight loss in animal models) ${ }^{35}$ ultimately constrain their clinical utility. Biochemical screening 
Scheme 1. Synthesis of Compounds $6 a-i^{a}$

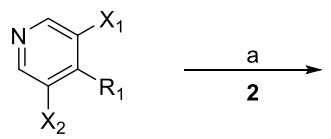

1a, $\mathrm{R}_{1}=\mathrm{Me}, \mathrm{X}_{1}=\mathrm{Br}, \mathrm{X}_{2}=\mathrm{Cl}$

1b, $\mathrm{R}_{1}=\mathrm{Et}, \mathrm{X}_{1}=\mathrm{Cl}, \mathrm{X}_{2}=\mathrm{Cl}$

1c, $\mathrm{R}_{1}=\mathrm{cPr}, \mathrm{X}_{1}=\mathrm{Cl}, \mathrm{X}_{2}=\mathrm{Cl}$

1d, $R_{1}=O M e, X_{1}=B r, X_{2}=B r$

1e, $\mathrm{R}_{1}=\mathrm{NH}_{2}, \mathrm{X}_{1}=\mathrm{Br}, \mathrm{X}_{2}=\mathrm{Cl}$

1f, $R_{1}=F, X_{1}=C l, X_{2}=\mathrm{Cl}$

1g, $\mathrm{R}_{1}=\mathrm{Cl}, \mathrm{X}_{1}=\mathrm{Br}, \mathrm{X}_{2}=\mathrm{Br}$

1h, $\mathrm{R}_{1}=\mathrm{CF}_{3}, \mathrm{X}_{1}=\mathrm{Br}, \mathrm{X}_{2}=\mathrm{Cl}$

1i, $\mathrm{R}_{1}=\mathrm{CN}, \mathrm{X}_{1}=\mathrm{Br}, \mathrm{X}_{2}=\mathrm{Cl}$

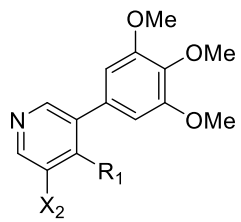

3a, $\mathrm{R}_{1}=\mathrm{Me}, \mathrm{X}_{2}=\mathrm{Cl}$

3b, $R_{1}=E t, X_{2}=C l$

3c, $\mathrm{R}_{1}=\mathrm{cPr}, \mathrm{X}_{2}=\mathrm{Cl}$

3d, $\mathrm{R}_{1}=\mathrm{OMe}, \mathrm{X}_{2}=\mathrm{Br}$

3e, $\mathrm{R}_{1}=\mathrm{NH}_{2}, \mathrm{X}_{2}=\mathrm{Cl}$

3f, $R_{1}=F, X_{2}=\mathrm{Cl}$

3g, $\mathrm{R}_{1}=\mathrm{Cl}, \mathrm{X}_{2}=\mathrm{Br}$

3h, $\mathrm{R}_{1}=\mathrm{CF}_{3}, \mathrm{X}_{2}=\mathrm{Cl}$

$3 i, R_{1}=C N, X_{2}=C l$
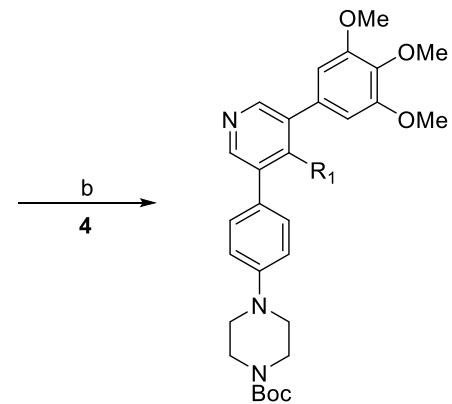

5a, $R_{1}=M e \quad 5 f, R_{1}=F$

$\mathbf{5 b}, \mathrm{R}_{1}=\mathrm{Et} \quad \mathbf{5 g}, \mathrm{R}_{1}=\mathrm{Cl}$

5c, $\mathrm{R}_{1}=\mathrm{cPr} \quad$ 5h, $\mathrm{R}_{1}=\mathrm{CF}_{3}$

5d, $\mathrm{R}_{1}=\mathrm{OMe} \quad \mathbf{5 i}, \mathrm{R}_{1}=\mathrm{CN}$

5e, $\mathrm{R}_{1}=\mathrm{NH}_{2}$

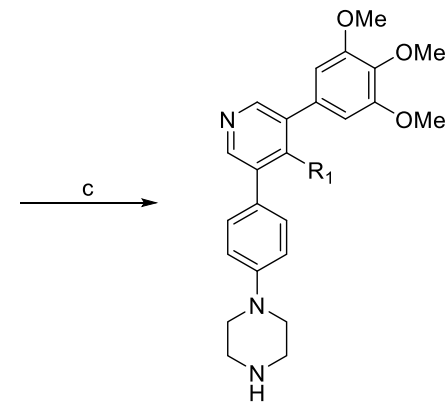

6a, $R_{1}=M e$

6b, $R_{1}=E t$

6h, $\mathrm{R}_{1}=\mathrm{CF}_{3}$

$6 d, R_{1}=O M e \quad 6 i, R_{1}=C N$

6e, $\mathrm{R}_{1}=\mathrm{NH}_{2}$

${ }^{a}$ Reagents and conditions: (a) 3,4,5-trimethoxyphenylboronic acid (2), $\mathrm{Pd}(\operatorname{dppf}) \mathrm{Cl}_{2} \cdot$ dichloromethane (DCM), $\mathrm{Na}_{2} \mathrm{CO}_{3}, \mathrm{~N}, \mathrm{~N}$-dimethylformamide $(\mathrm{DMF}) / \mathrm{H}_{2} \mathrm{O}, 100{ }^{\circ} \mathrm{C}, 16 \mathrm{~h}$ for $\mathbf{1 a}, \mathbf{1 d}-\mathbf{e}, \mathbf{1 g}$, $\mathbf{1 i}$ and XPhos Pd G2, $\mathrm{K}_{3} \mathrm{PO}_{4}$, butanol/ $\mathrm{H}_{2} \mathrm{O}, 100{ }^{\circ} \mathrm{C}, 4 \mathrm{~h}$ for $\mathbf{1 b}-\mathbf{c}, \mathbf{1 f}, \mathbf{1 h}$; (b) tert-butyl 4-[4-(4,4,5,5tetramethyl-1,3,2-dioxaborolan-2-yl)phenyl]piperazine-1-carboxylate (4), XPhos $\mathrm{Pd} \mathrm{G} 2, \mathrm{~K}_{3} \mathrm{PO}_{4}$, butanol/ $\mathrm{H}_{2} \mathrm{O}, 100{ }^{\circ} \mathrm{C}, 4 \mathrm{~h}$; (c) $4 \mathrm{M} \mathrm{HCl}$ in dioxane, $\mathrm{MeOH}$, room temperature (rt), $30 \mathrm{~min}$.

using recombinant ALK2 protein subsequently yielded a new series of inhibitors based on the 3,5-diphenylpyridine chemotype, typified by K02288, ${ }^{36}$ LDN-213844, and LDN-214117. ${ }^{37}$ More recently, the toolbox of compounds has been expanded through the discovery of a 3-(4-sulfamoylnaphthyl)pyrazolo[1,5-a]pyrimidine (modified LDN-193189) analog (Compound 23), ${ }^{38}$ as well as inhibitors based on quinazolinone (Compound 24), ${ }^{39}$ bis-heteroaryl pyrazole (Compound 18p), ${ }^{40}$ and macrocyclic (OD36) scaffolds. ${ }^{41}$ At the time of writing, a number of ALK2 inhibitors such as BLU-782 (IPN60130), BCX9250, and KER-047 are being explored for FOP, ${ }^{42}$ and another, Itacnosertib (TP-0184 from SumitomoTolero Pharma), has progressed into clinical trials (Phase I) as a treatment for DIPG.

Of the existing preclinical ALK2 inhibitors, LDN-193189, LDN-212854, and LDN-214117 have been examined in orthotopic in vivo models of DIPG owing to their suitable brain penetration, pharmacokinetic (PK) properties, and general tolerability. ${ }^{27,43}$ While LDN-212854 was found to be beneficial in a viral infection ACVR ${ }^{R 206 H}$ mouse model, ${ }^{27}$ both LDN-193189 and LDN-214117 showed significant 15 day prolongation of progression-free survival in mice bearing ACVR $1^{R 206 H}$ patient-derived xenografts. ${ }^{43}$ Given the positive in vivo outcome, we became interested in developing analogs of the lead compound LDN-214117 into potential clinical candidates. To expedite efforts, we adopted an open science model centered on the newly created M4K (Medicines4Kids) Pharma Inc., itself owned by the Agora Trust Fund. ${ }^{44,45}$

Although LDN-214117 has been demonstrated to have reasonable kinome-wide selectivity and low toxicity, ${ }^{37}$ we were particularly interested in increasing not only potency against ALK2 (to achieve a biochemical $\mathrm{IC}_{50}<20 \mathrm{nM}$ and cellular $\mathrm{IC}_{50}$ $<100 \mathrm{nM}$ ) but also the selectivity over the closely related type I TGF $\beta$ pathway receptor ALK5. Documented adverse effects of ALK5 inhibition include cardiotoxicity (valvular lesions), effects on bone growth (physeal dysplasia), and gastrointestinal inflammation, ${ }^{46}$ so $>50$-fold selectivity for ALK2 over ALK5 in biochemical and cell-based assays was deemed essential to establish a desired safety profile and mitigate potential toxicity associated with long-term dosing. Parallel selectivity over ALK4 and ALK7 would be beneficial for similar reasons, particularly since ALK4 is also involved in myostatin signaling, the impairment of which can result in muscle atrophy. ${ }^{47}$ Off-target toxicity related to other type I BMP pathway receptors may also be a concern given that inhibition of ALK1 has been associated with vascular effects (telangiectasia, edema, and congestive cardiac failure), ${ }^{48}$ and ALK3 is implicated in the regulation of iron storage. ${ }^{49}$ It should be noted, however, that ALK1-specific monoclonal antibody treatment administered to cancer patients did show a manageable safety profile with dosing up to $4.6 \mathrm{mg} /$ $\mathrm{kg}$ being well tolerated. ${ }^{50} \mathrm{~A}$ particular challenge in the development of selective, adenosine triphosphate (ATP)competitive small-molecule kinase inhibitors is the high degree of structural homology evident in the conserved ATP binding domains. For example, the ALK3 kinase domain possesses $66 \%$ sequence identity with that of ALK5, illustrative of the high structural homology among type I receptors of both the BMP and TGF $\beta$ signaling pathways. ${ }^{31}$ Within the BMP or TGF $\beta$ families, even greater kinase domain sequence identity is evident between homologues such as ALK1-ALK2 (79\%), ALK3ALK6 (86\%), and ALK4-ALK5 (90\%).

Additional considerations for inhibitor design included adjusting the molecular weight, number of hydrogen bond donor (HBD) and hydrogen bond acceptor (HBA) atoms, number of rotatable bonds, $\operatorname{cLog} P, \mathrm{p} K_{\mathrm{a}}$, topological polar surface area (tPSA), metabolic stability, and effective permeability to within the generally accepted parameters for successful CNS-directed drugs. ${ }^{51-53}$

Using the well-characterized pyrazolo $[1,5-a]$ pyrimidine inhibitor LDN-193189 as a control, we conducted the primary assessment of compound potency and selectivity against ALK1, ALK2, ALK2 mutants (G328V, R206H, and R258G), ALK3, ALK4, ALK5, and ALK6 using the radiometric in vitro kinase assay performed by Reaction Biology Corporation. Cellular activity against ALK2 in HEK-293 cells was determined by means of a NanoBRET assay employing competitive displacement of a fluorescent tracer (PBI-6908) from the binding pocket by test compounds and generation of $\mathrm{IC}_{50}$ values from the resultant reductions in bioluminescence resonance energy 
Table 1. Inhibitory and Off-Target Activities of LDN-213844, LDN-214117, and 6a-i<smiles>[R7]c1c(-c2ccc(N3CCNCC3)cc2)cncc1-c1cc(OC)c(OC)c(OC)c1</smiles>

\begin{tabular}{|c|c|c|c|c|c|c|c|}
\hline Compound & $\mathbf{R}_{\mathbf{1}}$ & $\operatorname{ALK2}^{a}{ }^{\prime} C_{50}(\mathrm{nM})$ & ALK5 IC $50(n M)$ & Fold Selectivity & $\begin{array}{c}\text { NanoBRET } \\
\text { ALK2 }^{a} \text { IC }_{50}(\mathrm{nM})\end{array}$ & $\begin{array}{c}\text { DLA } \\
\text { ALK5 IC }_{50}(\mathrm{nM})\end{array}$ & Cell-based Fold Selectivity \\
\hline LDN-213844 & & $\begin{array}{c}15^{*} \\
13^{b} \\
20^{(\mathrm{G} 328 \mathrm{~V})} \\
12^{(\mathrm{R} 206 \mathrm{H})} \\
4^{\text {(R258G) }}\end{array}$ & $\begin{array}{l}240^{*} \\
800^{b}\end{array}$ & $\begin{array}{c}16^{*} \\
62\end{array}$ & $58^{b}$ & $1350^{b}$ & 23 \\
\hline LDN-214117 & & $\begin{array}{c}24^{*} \\
115 \\
344^{(\mathrm{G} 328 \mathrm{~V})} \\
86^{(\mathrm{R} 206 \mathrm{H})} \\
19^{(\mathrm{R} 258 \mathrm{G})}\end{array}$ & $\begin{array}{l}3000 * \\
>2000\end{array}$ & $\begin{array}{l}125^{*} \\
>17\end{array}$ & 239 & $>5000$ & $>21$ \\
\hline $6 \mathbf{a}$ & $\mathrm{Me}$ & $\begin{array}{c}13^{c} \\
8^{(\mathrm{G} 328 \mathrm{~V})} \\
9^{(\mathrm{R} 206 \mathrm{H})} \\
13^{(\mathrm{R} 258 \mathrm{G})}\end{array}$ & $2427^{\circ}$ & 187 & $\begin{array}{c}45^{c} \\
6^{\left({ }^{(3328 V)}\right.} \\
16^{(\mathrm{G} 356 \mathrm{D})} \\
7^{(\mathrm{G} 207 \mathrm{D})} \\
12^{(\mathrm{R} 206 \mathrm{H})}\end{array}$ & $2712^{c}$ & 60 \\
\hline $6 \mathbf{b}$ & Et & 181 & $>5000$ & $>28$ & 589 & $>5000$ & $>8$ \\
\hline $6 c$ & $\mathrm{cPr}$ & 42 & 4658 & 111 & 159 & $>5000$ & $>31$ \\
\hline 6d & $\mathrm{OMe}$ & 103 & $>5000$ & $>49$ & 233 & $>5000$ & $>21$ \\
\hline $6 e$ & $\mathrm{NH}_{2}$ & 461 & $>5000$ & $>11$ & 255 & $>5000$ & $>20$ \\
\hline $6 f$ & $\mathrm{~F}$ & 15 & 880 & 59 & 32 & 2183 & 68 \\
\hline $6 \mathrm{~g}$ & $\mathrm{Cl}$ & 16 & 1330 & 83 & 57 & 9454 & 166 \\
\hline $6 \mathrm{~h}$ & $\mathrm{CF}_{3}$ & 67 & $>5000$ & $>75$ & 184 & $>5000$ & $>27$ \\
\hline $6 \mathbf{i}$ & $\mathrm{CN}$ & 3 & 731 & 244 & 15 & 679 & 45 \\
\hline
\end{tabular}

${ }^{a}$ Literature values. ${ }^{37}$ Measured values were determined using a radioactive biochemical kinase assay. ${ }^{b}$ ALK2 mutants are identified in parentheses. ${ }^{c}$ Average of duplicate measurements. ${ }^{d}$ Average of triplicate measurements.

transfer (BRET) ratios. A dual luciferase assay (DLA) was used to determine cellular activity against ALK5.

\section{RESULTS AND DISCUSSION}

Synthesis of C-4 Position Analogs. With reference to the cocrystal structure of the prototypic 3,5-diphenylpyridine inhibitor LDN-213844 bound to ALK2 (Figure 1B, PDB code $4 \mathrm{BGG}){ }^{37}$ it was anticipated that substitutions at the C-4 position could potentially allow for stronger hydrogen bonding to the amide of $\mathrm{H} 286$ in the hinge region through exertion of an electronic effect at the nitrogen of the pyridyl ring. Furthermore, the inhibitor's bioactive conformation appears to involve a dihedral angle between the pyridyl and C-3 position 3,4,5trimethoxyphenyl rings approaching $90^{\circ}$, a relatively high energy conformation $(2.5 \mathrm{kcal} / \mathrm{mol})$ that would be stabilized with the torsional restriction imposed by a sterically bulky C-4 position 

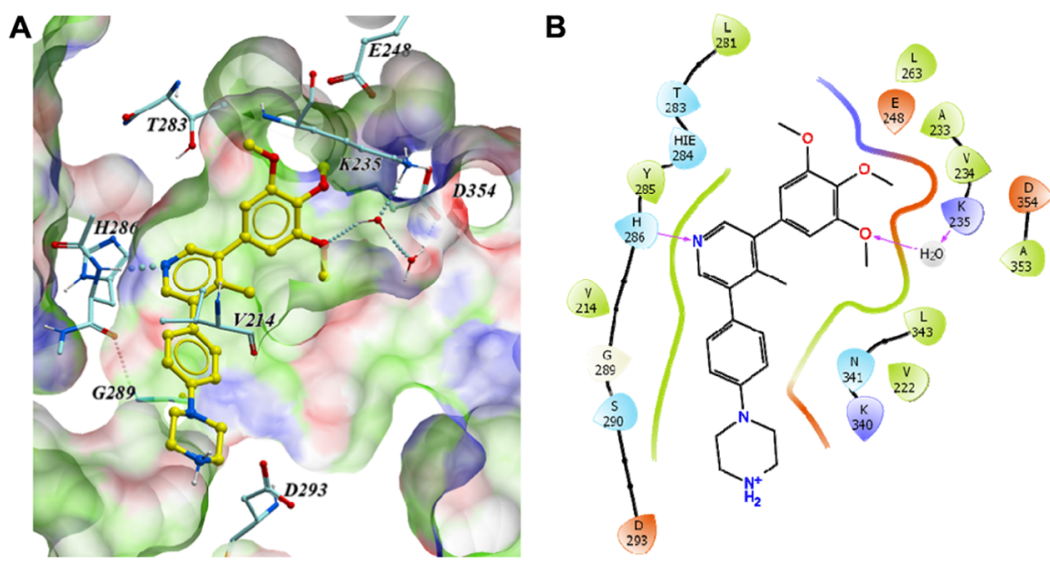

Figure 2. (A) Cocrystal structure of 6a (yellow) with ALK2 (PDB code 6SZM). Hydrogen bonds are established with H286 and K235. The 3,4,5trimethoxyphenyl moiety of 6a occupies a hydrophobic pocket (green) of ALK2 and is flanked by several hydrogen bond-donating (blue; K235) and hydrogen bond-accepting residues (red; D354 and E248). The protonated piperazine motif is in close proximity to D293, indicative of an electrostatic interaction. (B) Plot detailing the interactions of 6 a (black) within the ALK2 pocket.

substituent in a manner analogous to that of the C-2 position methyl substituent in LDN-214117. However, unlike in LDN214117, this locking of the conformation would also impact the dihedral angle between the pyridyl ring and the C-5 position 4piperazinophenyl ring, currently around $45^{\circ}$, pushing it toward $90^{\circ}$ and potentially setting up a more favorable $\pi-\pi$ stacking interaction of the phenyl ring between residues G289 and V214.

All C-4 position substituted analogs of LDN-213844 for our structure-activity relationship (SAR) study were synthesized using a route comprising an initial Suzuki-Miyaura coupling between commercially available 3,5-dihalopyridines $(\mathbf{1} \mathbf{a}-\mathbf{i})$ and 3,4,5-trimethoxyphenylboronic acid (2) to yield intermediates $3 a-i$, followed by a second coupling with 4-(4-tertbutoxycarbonylpiperazinyl)phenylboronic acid pinacol ester (4) and subsequent carbamate-protecting group removal from intermediates $\mathbf{5 a}-\mathbf{i}$ to yield the final inhibitors $6 \mathbf{a}-\mathbf{i}$ (Scheme 1 ). Although step a produced a significant amount of undesired dicoupling product $(\sim 50 \%)$ when starting with symmetrical 3,5dichloro- or 3,5-dibromopyridines ( $\mathbf{1 b}-\mathbf{d}$ and $\mathbf{1 f}-\mathbf{h})$, all steps were uniformly high yielding $(>70 \%)$ and purification of intermediates $3 \mathbf{a}-\mathbf{i}$ was not required. A range of electron donating group (EDG) and electron withdrawing group (EWG) substitutions at the $C-4$ position $\left(R_{1}\right)$ was readily accessible, and the corresponding inhibitors $\mathbf{6} \mathbf{a}-\mathbf{i}$ are summarized in Table 1 alongside reference compounds LDN-213844 and LDN214117.

C-4 Position Analog SAR. Interestingly, the SAR of inhibitors $6 \mathbf{a}-\mathbf{i}$ revealed a generally higher potency against ALK2 for inhibitors bearing an EWG at the C-4 position $(\mathbf{6} \mathbf{f}-\mathbf{i})$, with values near or below our set biochemical and cellular assay limits (20 and $100 \mathrm{nM}$, respectively). Compound $\mathbf{6 h}$ was an outlier, perhaps due to negation of the trifluoromethyl group's strong EWG character by a presumptive, unfavorable steric effect. Compounds with a weak or strong EDG at the C-4 position $(6 \mathbf{6}-\mathbf{c}$ and $\mathbf{6 d}-\mathbf{e}$, respectively) were generally less potent, although methyl substituted $6 \mathbf{a}$ was a notable exception. Overall, this observed electronic effect was counter to what was anticipated, with the compounds bearing an EDG at the C-4 position expected to have a more basic pyridyl nitrogen capable of forming a stronger hydrogen bond interaction with the backbone amide of $\mathrm{H} 286$. Compounds $\mathbf{6 a}$ and $\mathbf{6 f}-\mathbf{g}$ exhibited potencies similar to those reported for LDN-213844 and LDN$\mathbf{2 1 4 1 1 7 ^ { 3 7 }}$ although they were all considerably more potent than the later inhibitor was in our hands $\left(\mathrm{ALK} 2 \mathrm{IC}_{50}=115 \mathrm{nM}\right)$. Inhibitor $6 \mathbf{i}$ was particularly potent, and we believe it is the first reported $\mathrm{IC}_{50}<5 \mathrm{nM}$ inhibitor of ALK2.

Gratifyingly, all compounds showed an impressive level of selectivity for ALK2 over ALK5, equaling or exceeding levels exhibited by lead compounds LDN-213844 and LDN-214117. While generally high, this selectivity was relatively low in the biochemical assay for $\mathbf{6 f}$ with $\mathrm{R}_{1}=\mathrm{F}$. Given that this was the sterically smallest C-4 position substituent screened and resulted in ALK2 selectivity comparable to that of LDN-213844 where $\mathrm{R}_{1}=\mathrm{H}$, increased steric bulk at the $\mathrm{C}-4$ position may be at least a partial driver of selectivity through the enforcement of a favorable binding conformation. The same steric effect is likely seen in LDN-214117 where the C-2 position methyl group restricts rotation of the $\mathrm{C}-3$ position trimethoxyphenyl moiety relative to the pyridyl core and produces an ALK2 selectivity that is both significantly greater than that of LDN-213844 and more in line with that of $6 \mathbf{a}$ where $\mathrm{R}_{1}=\mathrm{Me}$ exerts a comparable steric influence.

Structural Basis for ALK2 Inhibition and Selectivity. Crystallographic efforts yielded a high-resolution (1.42 Å) cocrystal structure of $6 \mathrm{a}$ in the ATP pocket of the ALK2 Ser/Thr kinase domain (Figure 2A, PDB code 6SZM), confirming binding to the active A-loop DLG-in/ $\alpha$ C-helix-in conformation by means of a key ATP-mimetic hydrogen bond between the core pyridine nitrogen and the backbone amide of $\mathrm{H} 286$ in the hinge region. The C-3 position 3,4,5-trimethoxyphenyl moiety of 6 a occupies the hydrophobic pocket of ALK2 as expected, and the meta-methoxy group participates in a water-mediated hydrogen bond with $\mathrm{K} 235$. The aryl ring of the C-5 position 4-piperazinophenyl substituent stacks between G289 and V214, while the protonated secondary amine of the piperazine is in close proximity to D293 (5.11 $\AA$ between the 1-position piperazine nitrogen and D293 oxygen), suggestive of a solventmediated electrostatic ionic interaction.

As we were unable to obtain a cocrystal structure of 6 a with ALK5, it is difficult to fully rationalize the compound's evident selectivity for ALK2. With reference to LDN-213844, it was suggested that selectivity may be a consequence of dynamic conformational differences between ALK2 and ALK5 in tandem with effects exerted by the small number of sequence changes in the ATP pocket (see the Supporting Information, Figure S1). ${ }^{37}$ It can also be argued that the ATP pocket in many available 
ALK5 cocrystal structures shows a more open conformation than that of ALK2, the possible result of a smaller gatekeeper residue [S280 (ALK5 numbering) versus T283 (ALK2 numbering)]. Noticeable movement of the N-lobe away from the C-lobe in ALK5 structures changes the shape, volume, and dynamics of the ATP pocket, all of which have an effect on inhibitor binding. In addition, the conformational lock imposed on $6 \mathbf{a}$ by the presence of the $\mathrm{C}-4$ position methyl substituent enforces significant torsional angles $\left(\geq 45^{\circ}\right)$ evident between the core pyridine and the $\mathrm{C}-3$ and $\mathrm{C}-5$ position substituents, potentially aiding a preferential fit within the ALK2 pocket.

C-4 Position Analog Off-Target Activity. Compounds 6a, $\mathbf{6 f}-\mathbf{g}$, and $\mathbf{6 i}$ remained of interest given that they satisfied our ALK2 potency and selectivity criteria in both the biochemical and cell-based assays. Choosing $\mathbf{6 a}$ as an exemplar from this smaller set, we first determined the compound's potency against available ALK2 mutants (G328V, R206H, and R258G) in the biochemical assay. As expected, potency was in line with that observed against wild-type (WT) ALK2, comparable to the values obtained for LDN-213844, and superior to those recorded for LDN-214117. Inhibitor 6a also performed well when evaluated against ALK2 mutants (G328V, G356D, Q207D, and R206H) using the NanoBRET assay, showing that this favorable level of activity was undiminished in cells. It had previously been demonstrated that mutations in both the GS and Ser/Thr kinase domains of ALK2 had negligible effects on the kinase's affinity for ATP and type I kinase inhibitors, ${ }^{37}$ so for reasons of protein availability and assay expense, we opted to screen the inhibitory activity of all other compounds in our studies exclusively against WT ALK2.

In addition to the primary focus of limiting activity against ALK5, we hoped for a degree of selectivity for ALK2 over other off-targets of concern such as ALK1, ALK3, and ALK4. Profiling of representative compound 6 a revealed it to be equipotent on ALK1 $\left(\mathrm{IC}_{50}=15 \mathrm{nM}\right)$ but with modest 33-fold selectivity over ALK3 $\left(\mathrm{IC}_{50}=428 \mathrm{nM}\right)$ and substantial 103-fold selectivity over ALK4 $\left(\mathrm{IC}_{50}=1336 \mathrm{nM}\right)$. This later selectivity over ALK4 is a notable improvement over the 36 -fold selectivity exhibited by LDN-213844 $\left(\mathrm{IC}_{50}=462 \mathrm{nM}\right)$, again suggesting a possible role for the $\mathrm{C}-4$ position methyl as a selectivity element. Compounds of interest $6 \mathrm{f}\left(\mathrm{ALK} 4 \mathrm{IC}_{50}=630 \mathrm{nM}\right), 6 \mathrm{~g}\left(\mathrm{ALK} 4 \mathrm{IC}_{50}=962\right.$ $\mathrm{nM})$, and $6 \mathbf{i}\left(\mathrm{ALK} 4 \mathrm{IC}_{50}=257 \mathrm{nM}\right)$ also show improved 42-, 60-, and 86-fold selectivities (respectively) over ALK4, but all were less selective than 6a. Although of less concern as an offtarget, screening of 6a against ALK6 revealed only slight selectivity on the order of 5-fold (ALK6 $\left.\mathrm{IC}_{50}=68 \mathrm{nM}\right)$. All of these values are fully consistent with the aforementioned high degrees of structural homology among type I receptors of both the BMP and TGF $\beta$ signaling pathways, ${ }^{31}$ but the selectivity windows relating to critical off-targets ALK3, ALK4, and ALK5 suggest the possibility of a meaningful safety profile. Although potent against ALK1, based on past work, it is anticipated that any ALK1-driven toxicity arising from an inhibitor similar to 6 a could be managed through an appropriate dosing level or regimen. ${ }^{50}$ We did not have access to ALK7 during the course of this study and hence did not measure the potency of 6a against that target.

As previously mentioned, $\mathbf{L D N}-\mathbf{2 1 4 1 1 7}$ was demonstrated to have reasonable kinome-wide selectivity, ${ }^{37}$ with improvement over pyrazolo[1,5-a]pyrimidine inhibitors such as LDN193189. ${ }^{30}$ At $1 \mu \mathrm{M}, \mathrm{LDN}-214117$ inhibited only $3.6 \%$ of kinases $(\sim 200)$ profiled by more than 50\%, with ABL1, RIPK2, and TNIK being the most inhibited after ALK2. ${ }^{37}$ We screened 6a at $1 \mu \mathrm{M}$ against a significantly larger 374-member kinase set, finding remarkable selectivity with greater than $50 \%$ inhibition against only $2.1 \%$ of kinases (see the Supporting Information, Table S1). Of the eight kinases inhibited (ABL1, BRK, DDR1, MINK, NLK, SIK2, TNIK, and ZAK), 6a was only significantly potent against DDR1 $\left(\mathrm{IC}_{50}=41 \mathrm{nM}\right)$ and $\mathrm{TNIK}\left(\mathrm{IC}_{50}=96 \mathrm{nM}\right)$ (see the Supporting Information, Note $\mathrm{S} 1$ ), with $\mathrm{IC}_{50}$ values against the remaining six kinases in the 336-924 nM range.

To gauge the potential risk from another off-target related adverse drug reaction, $\mathbf{6} \mathbf{a}$ was screened in the Eurofins CerepPanlabs in vitro SafetyScreen 44 panel (see the Supporting Information, Table S2). At $10 \mu \mathrm{M}$, only five targets were inhibited more than $50 \%$, with 6 a being the most potent against the cannabinoid $\mathrm{CB}_{1}(97 \%)$ and adrenergic $\alpha_{2 \mathrm{~A}}(90 \%)$ receptors, followed by activity against the sodium channel site $2(72 \%)$, the human ether-a-go-go (hERG) potassium channel (69\%), and the adrenergic $\alpha_{1 \mathrm{~A}}(65 \%)$ receptor. A doseresponse follow-up at $3 \mu \mathrm{M}$ on the highly inhibited targets showed a cannabinoid $\mathrm{CB}_{1}$ receptor $\mathrm{IC}_{50}=1.72 \mu \mathrm{M}$ and an adrenergic $\alpha_{2 \mathrm{~A}}$ receptor $\mathrm{IC}_{50}=2.18 \mu \mathrm{M}$. With 6a showing greater than 100 -fold selectivity for ALK2 over these two targets, no significant concerns were registered in relation to these receptors.

Inhibition of the hERG potassium channel by $\mathbf{6 a}$ warranted further investigation given that loss of function is associated with long-QT syndrome type-2 (LQT2) and increased risk of potentially fatal torsades de pointes cardiac arrhythmia in vivo. ${ }^{54}$ Evaluation in the Charles River Laboratories ScreenPatch (patch clamp) assay found 6a to be only a moderate inhibitor of the hERG potassium channel $\left(\mathrm{IC}_{50}=8.3 \mu \mathrm{M}\right)$. To see if hERG potassium channel inhibition could be further attenuated through the incorporation of an EWG at the C-4 position, we also evaluated $\mathbf{6 g}$ and $\mathbf{6 i}$ but unfortunately found that both compounds were slightly more active with $\mathrm{IC}_{50}=2.7 \mu \mathrm{M}$ and $\mathrm{IC}_{50}=6.0 \mu \mathrm{M}$, respectively. Although an hERG potassium channel $\mathrm{IC}_{50}>10 \mu \mathrm{M}$ was desirable to limit the likelihood of cardiac toxicity, historic data pertaining to FDA-approved (tyrosine) kinase inhibitor drugs has shown that an $\mathrm{IC}_{50}<1 \mu \mathrm{M}$ is regarded as problematic, while an $\mathrm{IC}_{50}>3 \mu \mathrm{M}$ is generally acceptable. ${ }^{55}$ As such, we considered these compounds to have a manageable hERG potassium channel inhibition profile, which could be further derisked in a preclinical setting through in vivo canine electrophysiology studies. In addition, we engaged in structural modifications to the C-3 position 3,4,5-trimethoxyphenyl moiety and the $\mathrm{C}-5$ position 4-piperazinophenyl moiety, anticipating that those changes could potentially exert an influence on binding to the hERG potassium channel.

Screening of 6a by colleagues at Charles River Laboratories against seven major cytochrome P450 (CYP) enzyme isoforms (1A2, 2B6, 2C8, 2C9, 2C19, 2D6, and 3A4M/3A4T) in human liver microsomes at $30 \mu \mathrm{M}$ showed the compound to be clean, with $\mathrm{IC}_{50}>30 \mu \mathrm{M}$ on all targets except $3 \mathrm{~A} 4 \mathrm{~T}\left(\mathrm{IC}_{50}>9 \mu \mathrm{M}\right)$. To evaluate the mutagenic potential of $6 \mathbf{a}$, a Mini-Ames assay was conducted at $\mathrm{WuXi} A \mathrm{ppTec}$, concluding that the compound was negative for mutagenicity under the conditions of this study.

C-4 Position Substituent Selection. The activity and selectivity of inhibitors $\mathbf{6 a}, \mathbf{6} \mathbf{6}-\mathbf{g}$, and $\mathbf{6 i}$ provided us with four C4 position substituents that appeared suitable for inclusion in further analogs. Given the inefficiency inherent in the synthesis of $\mathbf{6} \mathbf{f}-\mathbf{g}$ (Scheme 1, step a) and their highly similar biochemical and cellular activity profiles in relation to $\mathbf{6 a}$, we opted to move forward only with analogs of compounds $\mathbf{6 a}$ and $\mathbf{6 i}$. The C-4 position methyl scaffold of 6 a was of particular interest given its 
Scheme 2. Synthesis of Compounds $11 a-c^{a}$<smiles>[R]c1c(Cl)cncc1Br</smiles>

1a, $\mathrm{R}_{1}=\mathrm{Me}$

$1 \mathrm{i}, \mathrm{R}_{1}=\mathrm{CN}$
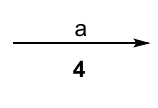

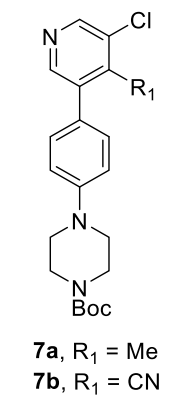

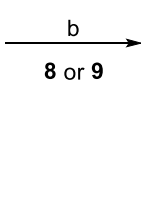

or 9<smiles>[R]c1c(OC)cc(-c2cncc(-c3ccc(N4CCN(C(=O)O)CC4)cc3)c2[R])cc1OC</smiles>

10a, $R_{1}=M e, R_{2}=H$

$10 b, R_{1}=M e, R_{2}=F$

10c, $R_{1}=C N, R_{2}=F$

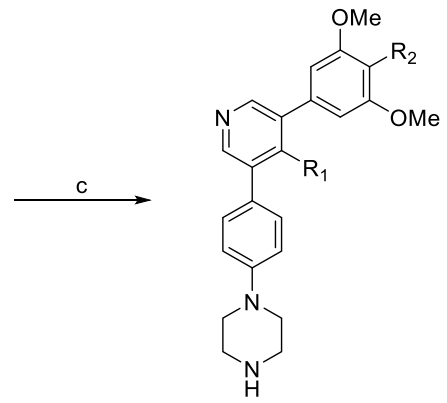

11a, $R_{1}=M e, R_{2}=H$ 11b, $R_{1}=M e, R_{2}=F$ 11c, $R_{1}=C N, R_{2}=F$

${ }^{a}$ Reagents and conditions: (a) tert-butyl 4-[4-(4,4,5,5-tetramethyl-1,3,2-dioxaborolan-2-yl)phenyl]piperazine-1-carboxylate (4), $\mathrm{Pd}(\mathrm{dppf}) \mathrm{Cl}_{2}$. DCM, $\mathrm{Na}_{2} \mathrm{CO}_{3}, \mathrm{DMF} / \mathrm{H}_{2} \mathrm{O}, 100{ }^{\circ} \mathrm{C}, 16 \mathrm{~h}$; (b) 3,5-dimethoxyphenylboronic acid (8) or (4-fluoro-3,5-dimethoxyphenyl)boronic acid (9), XPhos $\mathrm{Pd} \mathrm{G} 2, \mathrm{~K}_{3} \mathrm{PO}_{4}$, butanol $/ \mathrm{H}_{2} \mathrm{O}, 100{ }^{\circ} \mathrm{C}, 4 \mathrm{~h}$; (c) $4 \mathrm{M} \mathrm{HCl}$ in dioxane, $\mathrm{MeOH}, \mathrm{rt}, 30 \mathrm{~min}$.

Table 2. Inhibitory and Off-Target Activities of $6 \mathrm{a}$ and $11 \mathrm{a}-\mathrm{c}$<smiles>[R]c1c(OC)cc(-c2cncc(-c3ccc(N4CCNCC4)cc3)c2[R])cc1OC</smiles>

\begin{tabular}{|c|c|c|c|c|c|c|c|c|}
\hline Compound & $\mathbf{R}_{1} / \mathbf{R}_{2}$ & $\begin{array}{l}\text { cLogP } \\
\text { LipE }^{a}\end{array}$ & $\begin{array}{l}\operatorname{ALK2~IC~}{ }_{50} \\
(\mathrm{nM})\end{array}$ & $\begin{array}{c}\text { ALK5 IC } \text { IC } \\
\text { (nM) }\end{array}$ & $\begin{array}{c}\text { Fold } \\
\text { Selectivity }\end{array}$ & $\begin{array}{l}\text { NanoBRET } \\
\text { ALK2 IC } \text { IC }_{50} \\
\text { (nM) }\end{array}$ & $\begin{array}{c}\text { DLA } \\
\text { ALK5 IC } \text { IC }^{20} \\
(\mathrm{nM})\end{array}$ & $\begin{array}{l}\text { Cell-based Fold } \\
\text { Selectivity }\end{array}$ \\
\hline $6 a$ & $\begin{array}{l}\mathrm{Me} / \\
\mathrm{OMe}\end{array}$ & $\begin{array}{l}3.29 \\
4.60\end{array}$ & $13^{b}$ & $2427^{b}$ & 187 & $45^{b}$ & $2712^{b}$ & 60 \\
\hline $11 \mathrm{a}$ & $\mathrm{Me} / \mathrm{H}$ & $\begin{array}{l}3.95 \\
3.46\end{array}$ & 39 & $>5000$ & $>128$ & 440 & $>5000$ & $>11$ \\
\hline $11 \mathrm{~b}$ & $\mathrm{Me} / \mathrm{F}$ & $\begin{array}{l}3.72 \\
4.00\end{array}$ & 19 & 2206 & 116 & 98 & 7475 & 74 \\
\hline $11 \mathrm{c}$ & $\mathrm{CN} / \mathrm{F}$ & $\begin{array}{l}3.46 \\
4.50\end{array}$ & 11 & 487 & 44 & 49 & 1511 & 31 \\
\hline
\end{tabular}

${ }^{a} \operatorname{LipE}\left(\right.$ lipophilic efficiency) $=\mathrm{pIC}_{50}-\operatorname{cLog} P$, where $\mathrm{pIC}_{50}=-\log \mathrm{ALK} 2 \mathrm{IC}_{50}(\mathrm{nM}) .{ }^{b}$ Average of triplicate measurements.

favorable kinome-wide selectivity and off-target profiles detailed above, although 6i, despite its reduced cellular ALK2 selectivity, remained of interest because of its potency.

Synthesis of C-3 Position Analogs. Foundational SAR studies on K02288, LDN-213844, and LDN-214117 done by our collaborators led to discovery of the C-3 position 3,4,5trimethoxyphenyl substituent, an optimal group for providing interactions in the hydrophobic pocket as well as a watermediated hydrogen bond to K235. ${ }^{36,37}$ Critical to this hydrogen bond formation is the methoxy group at the 3-position of the phenyl ring, with both the 3- and 4-position methoxy groups engaged in bidentate hydrogen bonding evident in select cocrystal structures. Deletion of the 4-position methoxy group to produce a 3,5-dimethoxyphenyl moiety was tolerated, yielding almost equipotent compounds and suggesting that the phenyl ring was amendable to transformation. ${ }^{37}$ Our own extensive efforts to modify the 3,4,5-trimethoxyphenyl moiety in the context of LDN-213844 and 6a analogs by eliminating or altering substituents were largely unproductive, ${ }^{56}$ although limited success was achieved through replacement with a 2fluoro-6-methoxybenzamide moiety to yield equipotent inhibitors with reduced off-target affinity for the hERG potassium channel $\left(\mathrm{IC}_{50}>30 \mu \mathrm{M}\right) .{ }^{57}$ While the benzamide effectively recapitulated the water-mediated hydrogen bond to K235, its increased polarity had the unfortunate ancillary effect of making 
the compounds poorly brain-penetrant and limiting their usefulness for the treatment of DIPG.

The only suitable, novel modification to the 3,4,5trimethoxyphenyl group that emerged from our SAR studies on the LDN-213844 scaffold was replacement of the 4-position methoxy with fluorine, putatively capable of participating in an analogous water-mediated hydrogen bond to K235. We then looked to incorporate the required 4-fluoro-3,5-dimethoxyphenyl group at the $\mathrm{C}-3$ position of $\mathbf{6 a}$ and $\mathbf{6 i}$, alongside the aforementioned 3,5-dimethoxyphenyl group. This was readily accomplished by modifying the iterative Suzuki-Miyaura coupling sequence previously used for preparing the C-4 position analogs, yielding compounds 11a-c (Scheme 2). Common intermediates $7 \mathbf{a}-\mathbf{b}$, prepared first by attaching the C5 position tert-butyl-4-phenylpiperazine-1-carboxylate moiety, allowed for flexible, subsequent coupling of the C-3 position substituted phenyl group of choice (Table 2).

C-3 Position Analog SAR, Off-Target Activity, and Substituent Selection. While inhibitor 11a exhibited considerably reduced activity against ALK2 in cells, inhibitors $\mathbf{1 1} \mathbf{b}-\mathbf{c}$ were found to have activity profiles very similar to those of $6 \mathbf{a}$ and $6 \mathbf{i}$. Although potency against ALK2 was only slightly lower for $\mathbf{1 1 b}-\mathbf{c}$, selectivity over ALK5 in the biochemical assay dropped in both cases, with the effect being more pronounced for 11c (a drop from 244-fold to 44-fold) than for 11b (a drop from 187-fold to 116-fold). Interestingly, even though cellular activity against ALK2 was more than halved for both compounds, selectivity over ALK5 remained comparable at 74-fold and 31-fold for $\mathbf{1 1 b}$ and $11 \mathbf{c}$, respectively. The less than 50 -fold selectivity over ALK5 evident for 11 c in both assays led us to prioritize $\mathbf{1 1 b}$ as an analog of interest for which we also confirmed a slightly decreased 79-fold selectivity over ALK4 $\left(\mathrm{IC}_{50}=1503 \mathrm{nM}\right)$. We did not screen $11 \mathrm{~b}$ against ALK1, ALK2 mutants, ALK3, or ALK6 given the expectation of equipotency against these targets based on the patterns of activity evident from the screening of other compounds.

Screening of $\mathbf{1 1 b}$ at $1 \mu \mathrm{M}$ against a 374 -member kinase set, unsurprisingly, yielded greater than 50\% inhibition against seven of the eight kinases inhibited by $\mathbf{6 a}$ (ABL1, BRK, DDR1, MINK, SIK2, TNIK, and ZAK) although activity against NLK was diminished. In addition, $\mathbf{1 1} \mathbf{b}$ registered marginal activity (51$61 \%$ inhibition) against six other kinases (HGK, KHS, LCK, LYN, MLCK2, and SIK3) for a profile that involved an overall inhibition rate of $3.5 \%$ (see the Supporting Information, Table S1).

Activity against the hERG potassium channel as determined in the Charles River Laboratories ScreenPatch assay found $\mathbf{1 1} \mathbf{b}$ to be a more potent inhibitor than $6 \mathrm{a}$ with an $\mathrm{IC}_{50}=2.5 \mu \mathrm{M}$. While disappointing, this increased affinity for the hERG potassium channel was still within acceptable limits and viewed as a parameter that could potentially be impacted by replacement of the C-5 position 4-piperazinophenyl moiety in subsequent SAR studies. Compound $\mathbf{1 1 b}$ was also marginally more active when screened in the seven-member CYP panel. While 6a had an $\mathrm{IC}_{50}>30 \mu \mathrm{M}$ against six of the isoforms, $\mathbf{1 1 b}$ showed an $\mathrm{IC}_{50}>20 \mu \mathrm{M}$ against only four targets with the $2 \mathrm{C} 9$ $\mathrm{IC}_{50}=7.3 \mu \mathrm{M}, 2 \mathrm{C} 19 \mathrm{IC}_{50}=7.7 \mu \mathrm{M}$, and $3 \mathrm{~A} 4 \mathrm{~T} \mathrm{IC} \mathrm{IC}_{50}=14.3 \mu \mathrm{M}$.

While $11 \mathbf{b}$ was, in aggregate, a slightly inferior inhibitor with respect to $\mathbf{6} \mathbf{a}$ by the parameters detailed above, it constituted the only viable C-3 position analog that warranted further development. Aside from its comparable biochemical and cellbased activity on ALK2, $\mathbf{1 1 b}$ is a less polar compound (cLog $P=$ 3.72 and tPSA $\left.=46 \AA^{2}\right)$ than $6 \mathrm{a}(\operatorname{cLog} P=3.29$ and $\mathrm{tPSA}=55$
$\left.\AA^{2}\right),{ }^{58}$ suggesting it could potentially achieve a greater degree of brain penetration. As with the possibility to modify affinity toward the hERG potassium channel, changes in the C-5 position 4-piperazinophenyl moiety of 6 a were also viewed as a way to achieve tPSA values similar to that of $\mathbf{1 1 b}$ while preserving the C-3 position 3,4,5-trimethoxyphenyl moiety.

Synthesis of C-5 Position Analogs. With the C-3 and C-4 position substituents set, we endeavored to make changes to the C-5 position 4-piperazinophenyl moiety in an attempt to maintain or increase the activity against ALK2 shown by $6 \mathbf{a}$ and decrease the activity against the hERG potassium channel while remaining cognizant of several physiochemical parameters. In order for small-molecule inhibitors to penetrate the BBB and exert a pharmacological effect, their lipophilicity $(\operatorname{cLog} P)$, basicity $\left(\mathrm{p} K_{\mathrm{a}}\right)$, tPSA, and number of HBD/HBA (among other factors) ideally fall within a range of recommended values. ${ }^{51-53}$ Although enhanced drug potency and permeability are often a function of increased lipophilicity, a $c \log P<5$ is considered optimal to avoid potential concomitant increases in nonspecific tissue binding, which would ultimately decrease the concentration of free drug at its intended site of action within the brain. Possession of a positive charge at physiological $\mathrm{pH} 7-8$ favors brain permeation, so amine-containing compounds with a $\mathrm{p} K_{\mathrm{a}}=$ 7.5-10.5 are ideal despite the potential for issues with hERG potassium channel binding. Keeping the tPSA $<60-70 \AA^{2}$, the number of $\mathrm{HBD}<3$ (CNS drugs have a mean of 1.1), and the number of $\mathrm{HBA}<7$ are also favorable for $\mathrm{BBB}$ penetration and limiting recognition by efflux transporters such as $\mathrm{P}$ glycoprotein (P-gp). ${ }^{52,53}$ The calculated values for these primary metrics $^{58}$ informed our selection of suitable C-5 position substituents, the focus being on groups that would recapitulate, improve on, or not grossly deviate from the parameters of 6 a with a $\operatorname{cLog} P=3.29, \mathrm{p} K_{\mathrm{a}}=8.60, \mathrm{tPSA}=55 \AA^{2}, \mathrm{HBD}=1$, and $\mathrm{HBA}=6$.

The binding mode evident in the ALK2.6a cocrystal structure (Figure 2) has the phenyl ring of the C-5 position 4piperazinophenyl substituent stacking between G289 and V214, so we opted to retain the unmodified phenyl ring in future analogs while focusing on changes to the piperazine consistent with the physiochemical parameters detailed above. Again, published SAR studies pertaining to the C-5 position $^{37}$ as well as our own wide-ranging exploratory efforts ${ }^{56}$ built confidence in further narrowing the scope of our modifications. The challenge, however, was to attenuate the activity on the hERG potassium channel under these constraints, given that the C-5 position 4-piperazinophenyl substituent constitutes an ideal pharmacophore against the channel based on known ligandbased pharmacophore and QSAR models. ${ }^{59,60}$ While it is known that increasing the polarity of the drug molecule (lowering the cLog $P$ ) effectively reduces activity against the hERG potassium channel, our efforts to employ this strategy met with limited success as they produced a concomitant decrease in BBB penetration. ${ }^{57}$ Consequently, we focused our efforts on discrete structural modifications to the putative hERG potassium channel binding motif, which would affect the sterics and/or conformation around the 1-position piperazine nitrogen or reduce its basicity (lower the $\mathrm{p} K_{\mathrm{a}}$ ). These later strategies are known to effectively disrupt the cation $\pi$-stacking interactions between the basic amine-containing hERG potassium channel blockers and aromatic residues within the cavity of the channel at physiological $\mathrm{pH}$ and could be executed within the optimal parameters for CNS drugs described above. 
Scheme 3. Synthesis of Compounds $14 a-q^{a}$<smiles>Cc1c(Cl)cncc1Br</smiles><smiles>[10BH]C</smiles>

1a<smiles>COc1cc(-c2cncc(Cl)c2C)cc(OC)c1OC</smiles>

3a<smiles>[R]c1ccc(-c2cncc(-c3cc(OC)c(OC)c(OC)c3)c2C)cc1</smiles>

14a,b,h,i,k,m,o,q<smiles>[R]c1ccc(-c2cncc(-c3cc(OC)c(OC)c(OC)c3)c2C)cc1</smiles><smiles>COc1cc(-c2cncc(-c3ccc(N4CCNCC4)cc3)c2C)cc(OC)c1OC</smiles>

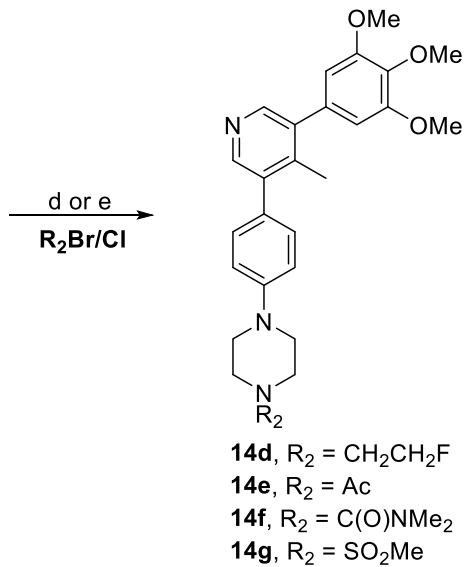

${ }^{a}$ Reagents and conditions: (a) 3,4,5-trimethoxyphenylboronic acid (2), $\mathrm{Pd}(\mathrm{dppf}) \mathrm{Cl}_{2} \cdot \mathrm{DCM}, \mathrm{Na}_{2} \mathrm{CO}_{3}, \mathrm{DMF} / \mathrm{H}_{2} \mathrm{O}, 100{ }^{\circ} \mathrm{C}, 16 \mathrm{~h}$; (b) 4 $\left(\mathrm{R}_{1}\right)$ phenylboronic acid or pinacol ester $(12 \mathrm{a}-\mathrm{c}$ and $\mathbf{1 2 h}-\mathbf{q})$, XPhos $\mathrm{Pd} \mathrm{G} 2, \mathrm{~K}_{3} \mathrm{PO}_{4}$, butanol/ $\mathrm{H}_{2} \mathrm{O}, 100{ }^{\circ} \mathrm{C}, 4 \mathrm{~h} ;(\mathrm{c})[\mathbf{1 3 c}, 13 \mathbf{j}, 13 \mathrm{l}, 13 \mathbf{n}, 13 \mathrm{p}], 4 \mathrm{M}$ $\mathrm{HCl}$ in dioxane, $\mathrm{MeOH}, \mathrm{rt}, 30 \mathrm{~min}$; (d) $\mathbf{R}_{2} \mathbf{O T s}$, triethylamine (TEA), acetonitrile, $100{ }^{\circ} \mathrm{C}, 16 \mathrm{~h}$ for $\mathbf{1 4 d}$; (e) $\mathbf{R}_{2} \mathbf{C l}, \mathrm{N}, \mathrm{N}$-diisopropylethylamine (DIPEA), tetrahydrofuran (THF), rt, $1 \mathrm{~h}$.

Analogs were accessed efficiently via common intermediates 3a and $\mathbf{6 a}$ incorporating the C-3 position 3,4,5-trimethoxyphenyl group, with the idea that analogs incorporating the alternate 4-fluoro-3,5-dimethoxyphenyl group could subsequently be prepared using only the optimal C-5 position substituents. Once again, the same sequential Suzuki-Miyaura coupling approach used for all previous analogs was employed to prepare new C-5 position analogs $14 a-c$ and $14 \mathbf{h}-\mathbf{q}$, with analogs $14 d-g$ accessed directly from 6 a through straightforward alkylation, acetylation, carbamoylation, or sulfonylation, respectively (Scheme 3). Synthesis was facilitated by the commercial availability of the requisite 4-substituted phenylboronic acids or pinacol esters $(12 \mathrm{a}-\mathrm{c}$ and $12 \mathrm{~h}-\mathrm{q})$, and the generally high coupling yields $(>70 \%)$ were encouraging for potential future scale-up requirements. An additional carbamate-protecting group removal step was required for the conversion of intermediates $13 c, 13 j, 131,13 n$, and $13 p$ to final inhibitors 14c, 14j, 14l, 14n, and $14 \mathrm{p}$, but additional purification of the final product was not required if previously conducted on the respective intermediate (Table 3).

C-5 Position Analog SAR, Off-Target Activity, and Substituent Selection. While unsurprising that methylation of $6 \mathrm{a}$ resulted in a compound with an almost identical activity and selectivity profile (14a), we were disappointed to find that sterically shielding the 1 -position piperazine nitrogen with a larger isopropyl group (14b) adversely impacted both the cellular activity on ALK2 and selectivity over ALK5. When the steric bulk was made adjacent to the same nitrogen through methylation of the C-2 and C-6 piperazine ring positions (14c), cellular activity against ALK2 was preserved, but selectivity over ALK5 still remained below our set 50-fold lower limit. While not entirely satisfactory, $\mathbf{1 4 b}-\mathrm{c}$ did still show reasonable levels of activity against ALK2 while maintaining $\operatorname{cLog} P, \mathrm{p} K_{\mathrm{a}}$, and tPSA values close to those of $6 \mathrm{a}$, so we used them to evaluate whether steric shielding of the 1-position piperazine nitrogen held any potential for mitigating activity on the hERG potassium channel. Unfortunately, both compounds were slightly more potent with hERG $\mathrm{IC}_{50}=3.1 \mu \mathrm{M}$ for $14 \mathrm{~b}$ and $\mathrm{hERG} \mathrm{IC}_{50}=5.9 \mu \mathrm{M}$ for $14 \mathrm{c}$.

Reluctant to further increase the overall molecular weight by exploring bulkier alkylic substituents, we turned our attention to attenuating the basicity of the 1-position piperazine nitrogen. It is known that introduction of fluorine as a hydrogen atom replacement in alkyl substituted amines can effectively modulate their basicity, with significant $\mathrm{p} K_{\mathrm{a}}$ shifts observed when the fluorine is installed at either the $\beta$-position $\left(\Delta \mathrm{p} K_{\mathrm{a}}-1.7\right)$ or the $\gamma$ position $\left(\Delta \mathrm{p} K_{\mathrm{a}}-0.7\right) .^{61}$ To that end, we prepared compound 14d bearing a 2-fluoroethyl group whose calculated $\mathrm{p} K_{\mathrm{a}}=7.49$ was a full 1.11 units lower than that of $6 a$. While comparably active against ALK2 in the biochemical assay, cellular activity $\left(\mathrm{IC}_{50}=178 \mathrm{nM}\right)$ was greatly diminished, placing the compound well beyond our acceptable limit. Acetylation, carbamoylation, and sulfonylation of the nitrogen designed to effectively abolish basicity while introducing oxygen atoms with HBA potential afforded compounds $14 \mathrm{e}-\mathrm{g}$. Inhibitors $14 \mathrm{e}-\mathrm{f}$ were poorly active against ALK2 in cells, while $\mathbf{1 4 g}$ exhibited activity similar to that of 6 a with the benefit of a near doubling in selectivity over ALK5 to 108 -fold. Significantly, 14g had an hERG $\mathrm{IC}_{50}>50 \mu \mathrm{M}$, likely resulting from both the decrease in basicity and a $26 \AA^{2}$ 
Table 3. Inhibitory and Off-Target Activities of $6 a$ and $14 a-q^{b}$<smiles>[R3]c1ccc(-c2cncc(-c3cc(OC)c(OC)c(OC)c3)c2C)cc1</smiles>

\begin{tabular}{|c|c|c|c|c|c|c|c|c|c|}
\hline Compound & $\mathbf{R}_{1}$ & $\begin{array}{c}\text { cLogP } \\
\text { pKa } \\
\text { tPSA } \\
\left(\AA^{2}\right) \\
\text { LipE }^{a}\end{array}$ & $\begin{array}{l}\operatorname{ALK2~IC}_{50} \\
(\mathrm{nM})\end{array}$ & $\begin{array}{c}\operatorname{ALK5~IC~}_{50} \\
(\mathrm{nM})\end{array}$ & $\begin{array}{c}\text { Fold } \\
\text { Selectivity }\end{array}$ & $\begin{array}{c}\text { NanoBRET } \\
\text { ALK2 } \\
\text { IC }_{50} \\
(\mathrm{nM})\end{array}$ & $\begin{array}{c}\text { DLA } \\
\text { ALK5 IC } \\
\text { (nM) }\end{array}$ & $\begin{array}{l}\text { Cell-based Fold } \\
\text { Selectivity }\end{array}$ & $\begin{array}{c}\text { hERG } \\
\text { IC } \\
(\mu \mathrm{M})\end{array}$ \\
\hline $6 a$ & & $\begin{array}{c}3.29 \\
8.60 \\
55 \\
4.60\end{array}$ & $13^{b}$ & $2427^{b}$ & 187 & $45^{b}$ & $2712^{b}$ & 60 & 8.3 \\
\hline $14 a$ & & $\begin{array}{c}3.74 \\
8.56 \\
47 \\
4.31\end{array}$ & 9 & 4847 & 539 & 56 & $>5000$ & $>89$ & - \\
\hline $14 \mathrm{~b}$ & & $\begin{array}{c}4.58 \\
8.65 \\
47 \\
3.57\end{array}$ & 7 & 2236 & 319 & 73 & 1824 & 25 & 3.1 \\
\hline $14 \mathrm{c}$ & & $\begin{array}{c}4.32 \\
8.74 \\
55 \\
3.78\end{array}$ & 8 & 1050 & 131 & 40 & 1427 & 36 & 5.9 \\
\hline $14 d$ & & $\begin{array}{c}3.99 \\
7.49 \\
47 \\
3.78\end{array}$ & 17 & 3215 & 189 & 178 & $>5000$ & $>28$ & - \\
\hline $14 \mathrm{e}$ & & $\begin{array}{c}2.88 \\
- \\
64 \\
4.78\end{array}$ & 22 & 2524 & 115 & 267 & $>5000$ & $>19$ & - \\
\hline $14 \mathrm{f}$ & & $\begin{array}{c}3.97 \\
- \\
67 \\
4.43\end{array}$ & 4 & $>5000$ & $>1250$ & 149 & $>5000$ & $>34$ & - \\
\hline $14 \mathrm{~g}$ & & $\begin{array}{c}3.30 \\
- \\
81 \\
4.24\end{array}$ & 29 & 1983 & 68 & 59 & 6392 & 108 & $>50$ \\
\hline $14 \mathrm{~h}$ & & $\begin{array}{c}3.30 \\
- \\
53 \\
4.25\end{array}$ & 28 & 2356 & 84 & 334 & $>5000$ & $>15$ & - \\
\hline $14 \mathrm{i}$ & & $\begin{array}{c}2.33 \\
- \\
77 \\
5.47\end{array}$ & 16 & 1229 & 77 & 169 & $>5000$ & $>30$ & - \\
\hline $14 \mathrm{j}$ & & $\begin{array}{c}3.93 \\
9.84 \\
52 \\
4.12\end{array}$ & 9 & 1745 & 194 & 54 & 3421 & 63 & - \\
\hline $14 \mathrm{k}$ & & $\begin{array}{c}4.21 \\
9.79 \\
43 \\
3.94\end{array}$ & 7 & $>5000$ & $>714$ & 29 & 3326 & 115 & 4.8 \\
\hline 141 & & $\begin{array}{c}3.83 \\
9.17 \\
52 \\
4.47\end{array}$ & 5 & $>5000$ & $>1000$ & 47 & 7532 & 160 & 3.4 \\
\hline
\end{tabular}


Table 3. continued

\begin{tabular}{|c|c|c|c|c|c|c|c|c|c|}
\hline Compound & $\mathbf{R}_{\mathbf{1}}$ & $\begin{array}{c}\operatorname{cLogP} \\
\text { pK } \\
\text { tPSA } \\
\left(\AA^{2}\right) \\
\text { LipE }^{a}\end{array}$ & $\begin{array}{c}\operatorname{ALK2~IC}_{50} \\
(\mathrm{nM})\end{array}$ & $\underset{(\mathrm{nM})}{\operatorname{ALK5~IC~}_{50}}$ & $\begin{array}{c}\text { Fold } \\
\text { Selectivity }\end{array}$ & $\begin{array}{c}\text { NanoBRET } \\
\text { ALK2 } \\
\text { IC } 50 \\
(n M)\end{array}$ & $\begin{array}{c}\text { DLA } \\
\text { ALK5 IC }_{50} \\
\text { (nM) }\end{array}$ & $\begin{array}{l}\text { Cell-based Fold } \\
\text { Selectivity }\end{array}$ & $\begin{array}{c}\text { hERG } \\
\text { IC } \\
(\mu \mathrm{M})\end{array}$ \\
\hline $14 \mathrm{~m}$ & & $\begin{array}{c}4.11 \\
9.12 \\
43 \\
3.74\end{array}$ & 14 & 2520 & 180 & 102 & 7803 & 77 & - \\
\hline $14 n$ & & $\begin{array}{c}3.33 \\
9.26 \\
55 \\
4.56\end{array}$ & 13 & 3050 & 235 & 83 & 4531 & 55 & - \\
\hline 140 & & $\begin{array}{c}3.92 \\
3.48 \\
47 \\
3.78\end{array}$ & 20 & 2643 & 132 & 108 & $>5000$ & $>46$ & - \\
\hline $14 p$ & & $\begin{array}{c}3.36 \\
9.45 \\
61 \\
4.86\end{array}$ & 6 & 2854 & 476 & 31 & 1908 & 62 & 8.1 \\
\hline $14 q$ & & $\begin{array}{c}3.64 \\
9.40 \\
53 \\
4.58\end{array}$ & 6 & 1650 & 275 & 67 & 2094 & 31 & - \\
\hline
\end{tabular}

${ }^{a} \mathrm{LipE}$ (lipophilic efficiency) $=\mathrm{pIC}_{50}-\operatorname{cLog} P$, where $\mathrm{pIC}_{50}=-\log \mathrm{ALK} 2 \mathrm{IC}_{50}(\mathrm{nM}) .{ }^{b}$ Average of triplicate measurements.

increase in tPSA over 6a to $81 \AA^{2}$. Although this value was beyond the generally favorable tPSA $<60-70 \AA^{2}$ range for CNS drugs, we felt that further evaluation of this compound was warranted.

Having demonstrated with compound $14 \mathrm{~g}$ that it was possible to achieve potency against ALK2 in the absence of a basic piperazine nitrogen, we endeavored to replace the piperazine with morpholine (14h) and thiomorpholine 1,1-dioxide (14i). Designed to remove the 1-position piperazine nitrogen entirely and access the potential HBA capacity offered by oxygen, these compounds showed poor cellular activity against ALK2 despite having reasonable values in the biochemical assay. Removal of the other, less basic 4-position piperazine nitrogen was also examined via the synthesis of piperidine-containing inhibitors $\mathbf{1 4} \mathbf{j}-\mathbf{k}$ and 1,2,3,6-tetrahydropyridine-containing inhibitors 141-m, both with different ring topology and conformation in an attempt to influence hERG potassium channel binding. Inhibitor $\mathbf{1 4} \mathbf{j}$ was found to have an activity and selectivity profile almost identical to that of $6 a$, but we were particularly attracted by its methylated analog 14k, which exhibited superior cellular activity $\left(\mathrm{ALK} 2 \mathrm{IC}_{50}=29 \mathrm{nM}\right)$ and selectivity over ALK5 (115fold). Interestingly, in the 1,2,3,6-tetrahydropyridine containing inhibitor pair, unmethylated analog 141 was superior to $14 \mathrm{~m}$ in both activity (ALK2 $\left.\mathrm{IC}_{50}=47 \mathrm{nM}\right)$ and selectivity over ALK5 (160-fold). Unfortunately, neither the changed electronics nor the conformation embodied in the piperidine and 1,2,3,6tetrahydropyridine rings of $14 \mathrm{k}-\mathbf{l}$ served to decrease activity against the hERG potassium channel, with the compounds registering an hERG $\mathrm{IC}_{50}=4.8 \mu \mathrm{M}$ and hERG $\mathrm{IC}_{50}=3.4 \mu \mathrm{M}$, respectively. However, in contrast to $6 \mathrm{a}(\operatorname{cLog} P=3.29$, tPSA $=$ $55), \quad 14 \mathbf{k}$ was of particular interest given its increased lipophilicity $(\operatorname{cog} P=4.21$, tPSA $=43)$ and attendant potential for greater $\mathrm{BBB}$ penetration. We replaced the $\mathrm{C}-3$ position $3,4,5-$ trimethoxyphenyl group of $\mathbf{1 4 k}$ with the previously explored 4fluoro-3,5-dimethoxyphenyl group to access an even more lipophilic analog $(\operatorname{cLog} P=4.65$, tPSA $=35)$ but did not pursue the resulting compound further as it showed decreased cell- based activity (ALK2 $\left.\mathrm{IC}_{50}=77 \mathrm{nM}\right)$ and poorer selectivity over $\operatorname{ALK}$ (61-fold). ${ }^{56}$

Further attempts at instituting conformational changes around the piperazine ring involved its enlargement to homopiperazine (14n) and introduction of a benzylic carbon linker between it and the C-5 position phenyl ring (14o). Both changes produced slightly less active and selective compounds in cells, but the activity of $\mathbf{1 4 0}$ raised the possibility of employing an analogous spacer in combination with the piperidine moiety found to be potent in compounds $\mathbf{1 4 j - k}$. To overcome the potential metabolic liabilities associated with benzylic carbons, we switched to a phenolic oxygen linker for the synthesis of $14 p-q$. We were pleasantly surprised to see that $14 p$ in particular had an activity and selectivity profile comparable to that of $\mathbf{6 a}$ and that this profile extended its activity against the hERG potassium channel $\left(\mathrm{IC}_{50}=8.1 \mu \mathrm{M}\right)$. While there was no reduction in the hERG potassium channel binding affinity, $14 p$ did still offer a viable alternative chemotype for advancement into further studies.

While we deemed it unnecessary to screen $14 \mathrm{~g}, 14 \mathrm{k}-1$, and $14 p$ against ALK1, ALK2 mutants, ALK3, or ALK6 based on the known pattern of activity for this class of compounds (see above), we did spot-check the activity of these compounds against ALK4. 14k-1 had an ALK4 $\mathrm{IC}_{50}>2000 \mathrm{nM}$, with only relatively marginal activity shown by $\mathbf{1 4 g}\left(\mathrm{ALK} 4 \mathrm{IC}_{50}=1131\right.$ $\mathrm{nM})$ and $14 \mathrm{p}\left(\mathrm{ALK} 4 \mathrm{IC}_{50}=1363 \mathrm{nM}\right)$ corresponding to 39-fold and 227-fold selectivity for ALK2, respectively. Although the reduced selectivity of $\mathbf{1 4} \mathbf{g}$ over ALK4 was of some concern, we still felt that analysis of its absorption, distribution, metabolism, and excretion (ADME) and PK properties was warranted based on the compound's relatively high cellular potency against ALK2, significant selectivity over ALK5, and lack of affinity for the hERG potassium channel. As an interesting, representative piperidine-containing inhibitor, we screened $14 \mathbf{k}$ at $1 \mu \mathrm{M}$ against the 374-member kinase panel, finding $>50 \%$ inhibition against only $1.9 \%$ of the kinases (see the Supporting Information, Table S1). All of the seven kinases inhibited 
Table 4. In Vitro ADME Parameters for $6 \mathrm{a}, 11 \mathrm{~b}, 14 \mathrm{~g}, 14 \mathrm{k}-1$, and $14 \mathrm{p}^{e}$<smiles>[R]c1ccc(-c2cncc(-c3cc(OC)c([R1])c(OC)c3)c2C)cc1</smiles>

\begin{tabular}{|c|c|c|c|c|c|c|c|c|c|}
\hline \multirow[b]{2}{*}{ Compound } & \multirow[b]{2}{*}{$\mathbf{R}_{\mathbf{1}}$} & \multirow[b]{2}{*}{$\mathbf{R}_{\mathbf{2}}$} & \multicolumn{2}{|c|}{ Microsomal Stability Assay ${ }^{a}$} & \multicolumn{3}{|c|}{ Caco-2 Permeability Assay $^{b, c}$} & \multicolumn{2}{|c|}{ PPB Assay } \\
\hline & & & $\begin{array}{c}\text { MLM } \\
(\%)\end{array}$ & $\begin{array}{c}\text { HLM } \\
(\%)\end{array}$ & $\begin{array}{c}P_{\text {app AB }} \\
\left(10^{-6} \mathrm{~cm} / \mathrm{s}\right)\end{array}$ & $\begin{array}{c}P_{\text {app BA }} \\
\left(10^{-6} \mathrm{~cm} / \mathrm{s}\right)\end{array}$ & $\begin{array}{c}\text { Efflux } \\
\text { Ratio }\end{array}$ & $\begin{array}{c}\text { Binding } \\
(\%)\end{array}$ & $\begin{array}{c}\text { Free } \\
(\%)\end{array}$ \\
\hline $6 a$ & $\mathrm{OMe}$ & & $64.6^{d}$ & $71.4^{d}$ & $5.4^{d}$ & $8.0^{d}$ & 1.5 & $94.3^{d}$ & $5.7^{d}$ \\
\hline $11 b$ & $\mathrm{~F}$ & & $65.8^{d}$ & $83.7^{d}$ & $1.8^{e}$ & 4.9 & 2.7 & 99.6 & 0.4 \\
\hline $14 \mathrm{~g}$ & $\mathrm{OMe}$ & & 100 & 83.6 & 34.5 & 33.8 & 1.0 & - & - \\
\hline $14 k$ & $\mathrm{OMe}$ & & 55.5 & 71.2 & 9.7 & 8.1 & 0.8 & 95.0 & 5.0 \\
\hline 141 & $\mathrm{OMe}$ & & 73.9 & 68.0 & 2.9 & 3.9 & 1.3 & - & - \\
\hline $14 p$ & $\mathrm{OMe}$ & & 39.3 & 62.1 & 4.1 & 9.4 & 2.3 & - & - \\
\hline
\end{tabular}

${ }^{a}$ Stability classification: stable $(>70 \%)$, moderately stable $(20-70 \%)$, or unstable $(<20 \%)$ compound remaining. ${ }^{b}$ Permeability classification: low $\left(P_{\text {app }}<1\right)$, medium $\left(P_{\text {app }} 1-3\right)$, or high $\left(P_{\text {app }}>3\right) \times 10^{-6} \mathrm{~cm} / \mathrm{s} .{ }^{c}$ Efflux ratio $(\mathrm{BA} / \mathrm{AB})$ classification: negative $($ ratio $<2)$, minor/moderate $($ ratio $2-7$ ), or high (ratio > 7). ${ }^{d}$ Average of duplicate measurements. ${ }^{e}$ Poor post-assay recovery in A to B chambers possibly due to low aqueous solubility, high lipophilicity, nonspecific binding to plastics or cells, and/or poor intracellular stability of the test article.

(ABL1, BRK, DDR1, LYN, MINK, TNIK, and ZAK) had also been inhibited by $\mathbf{6 a}$ and/or $\mathbf{1 1} \mathbf{b}$.

In Vitro ADME. Presented with six compounds exhibiting the structural attributes of a potentially successful CNS drug while meeting our criteria for activity against ALK2, selectivity over ALK5, and binding to the hERG potassium channel, we moved to evaluate the in vitro stability, permeability, and plasma protein binding (PPB) of $\mathbf{6 a}, \mathbf{1 1} \mathbf{b}, \mathbf{1 4}, \mathbf{g}, \mathbf{1 4 k}-\mathbf{l}$, and $\mathbf{1 4 p}$ (Table 4). Phase I (CYP enzymes only) metabolic stability of the compounds was examined at $1 \mu \mathrm{M}$ in both mouse and human liver microsomes (MLM and HLM) following a $60 \mathrm{~min}$ incubation period at 37 ${ }^{\circ} \mathrm{C}$, permeability was assessed using a Caco- 2 assay, and heparinized pooled human plasma coupled with a compound concentration of $5 \mu \mathrm{M}$ and $4 \mathrm{~h}$ incubation period at $37^{\circ} \mathrm{C}$ was used for PPB determination.

We were pleased to find that across both the MLM and HLM assays, all of the compounds could be classified as being at least moderately stable (20-70\% remaining), with some showing higher degrees of stability (>70\% remaining). Compound $14 \mathbf{p}$ appeared to be the most labile, although it still demonstrated adequate stability to remain of interest. While it had been reported that the piperazine moiety of LDN-193189 is a metabolic liability, ${ }^{38}$ the motif did not appear to present any significant issue in the context of our 3,5-diphenylpyridine class 
Table 5. In Vivo PK and ADME Parameters for 6a, 11b, 14g, 14k-1, and 14p $\mathrm{p}^{c}$<smiles>[R]c1ccc(-c2cncc(-c3cc(OC)c([R17])c(OC)c3)c2C)cc1</smiles>

\begin{tabular}{|c|c|c|c|c|c|c|c|c|c|}
\hline \multirow{3}{*}{ Compound } & \multirow{3}{*}{$\mathbf{R}_{1}$} & \multirow{3}{*}{$\mathbf{R}_{2}$} & \multicolumn{7}{|c|}{ PK in Female SCID Mice and Male SD Rats ${ }^{a}(n=3)$} \\
\hline & & & \multicolumn{2}{|c|}{$2 \mathrm{mg} / \mathrm{kg}$ IV } & \multicolumn{5}{|c|}{$10 \mathrm{mg} / \mathrm{kg}$ PO } \\
\hline & & & $\begin{array}{c}\mathrm{Cl} \\
(\mathrm{mL} / \mathrm{min} / \mathrm{kg})\end{array}$ & $\begin{array}{c}V_{\text {ss }} \\
(\mathbf{L} / \mathbf{k g})\end{array}$ & $\begin{array}{l}t_{1 / 2} \\
\text { (h) }\end{array}$ & $\begin{array}{r}C_{\max } \\
(\mu \mathrm{M})\end{array}$ & $\begin{array}{l}A U C_{\text {inf }} \\
(\mathbf{h} \cdot \mu \mathrm{M})\end{array}$ & $\begin{array}{c}F \\
(\%)\end{array}$ & $\begin{array}{c}C_{\text {brain }} / C_{\text {plasma }} \\
\text { @ } 4 \mathrm{~h}\end{array}$ \\
\hline $6 a$ & $\mathrm{OMe}$ & & $\begin{array}{l}12.7 \\
22.1\end{array}$ & $\begin{array}{l}2.05 \\
5.22\end{array}$ & $\begin{array}{l}3.11 \\
3.58\end{array}$ & $\begin{array}{l}6.16 \\
1.28\end{array}$ & $\begin{array}{l}51.7 \\
17.4\end{array}$ & $\begin{array}{c}100 \\
96\end{array}$ & $0.90^{b}$ \\
\hline $11 b$ & F & & $\begin{array}{l}17.1 \\
22.6\end{array}$ & $\begin{array}{l}2.77 \\
6.62\end{array}$ & $\begin{array}{l}3.68 \\
7.59\end{array}$ & $\begin{array}{l}3.19 \\
0.81\end{array}$ & $\begin{array}{l}22.7 \\
13.4\end{array}$ & $\begin{array}{l}95 \\
74\end{array}$ & $\begin{array}{l}1.41 \\
2.03^{c}\end{array}$ \\
\hline $14 \mathrm{~g}$ & $\mathrm{OMe}$ & & 7.90 & 0.48 & 0.80 & 1.43 & 2.97 & 7 & - \\
\hline $14 k$ & $\mathrm{OMe}$ & & $\begin{array}{l}8.90 \\
15.1\end{array}$ & $\begin{array}{l}2.44 \\
4.33\end{array}$ & $\begin{array}{l}3.67 \\
3.90\end{array}$ & $\begin{array}{l}4.74 \\
1.16\end{array}$ & $\begin{array}{l}32.4 \\
12.9\end{array}$ & $\begin{array}{l}74 \\
50\end{array}$ & $\begin{array}{l}0.82 \\
1.55^{c}\end{array}$ \\
\hline 141 & $\mathrm{OMe}$ & & 3.84 & 1.66 & 6.02 & 6.62 & 82.5 & 79 & 0.43 \\
\hline $14 p$ & $\mathrm{OMe}$ & & 6.00 & 2.23 & 7.70 & 4.71 & 65.8 & 96 & - \\
\hline
\end{tabular}

${ }^{a}$ Italicized table entries. ${ }^{b}$ Male CD-1 mice at 2 h. ${ }^{c}$ Compound administered at $100 \mathrm{mg} / \mathrm{kg}$ PO.

inhibitors with a half-life greater than 60 min apparent for all compounds.

Caco-2 permeability values were also high, with $P_{\mathrm{app} \_\mathrm{AB}} \geq 3 \times$ $10^{-6} \mathrm{~cm} / \mathrm{s}$ for all compounds except for $11 \mathrm{~b}$. Although the compound was found to be moderately permeable with a $P_{\text {app } \_ \text {AB }}$ $=1.8 \times 10^{-6} \mathrm{~cm} / \mathrm{s}$, poor post-assay recovery $(<15 \%)$ for this compound, possibly a function of its increased lipophilicity, rendered the value less accurate. It also appeared that compounds $6 \mathrm{a}, 14 \mathrm{~g}$, and $14 \mathrm{k}-1$ were not subject to P-gpmediated efflux, with $11 \mathrm{~b}$ and $14 \mathrm{p}$ being only moderately so. These low efflux ratios, coupled with high $P_{\text {app_AB }}$ values and microsomal stability, suggested that all compounds were suitable candidates for in vivo analysis.
Measurement of PPB for 6a $(\operatorname{cLog} P=3.29), 11 b(\operatorname{cLog} P=$ 3.72 ), and $14 \mathrm{k}(\operatorname{cog} P=4.21)$ showed $6 \mathrm{a}$ and $14 \mathrm{k}$ to have comparable, "druglike" free fractions (5.7 and 5.0\%, respectively) despite their difference in lipophilicity. Although the $0.4 \%$ free fraction of $\mathbf{1 1} \mathbf{b}$ appears suboptimal in comparison, current understanding reveals that in vitro PPB does not determine the actual unbound concentration in plasma in vivo, and as such, optimizing for PPB in drug design is not recommended. ${ }^{62}$ For drugs targeting the CNS, it is suggested that efforts should focus on reducing drug efflux transport at the $\mathrm{BBB}$ to achieve a high unbound brain concentration and to use $\mathrm{PPB}$ and brain tissue binding to calculate the unbound brain to 
unbound plasma concentration ratio for brain distribution assessment.

In Vivo PK and ADME. Given the favorable in vivo PK properties, suitable brain penetration, and general tolerability of LDN-214117 facilitating its successful use in orthotopic in vivo models of DIPG, ${ }^{43}$ we felt confident that our modified, yet structurally related compounds would exhibit comparable or superior characteristics. To that end, we initially chose to evaluate the in vivo PK profiles of $6 \mathrm{a}, 11 \mathrm{~b}, 14 \mathrm{~g}, 14 \mathrm{k}-\mathrm{l}$, and $14 \mathrm{p}$ in female CB17 SCID mice following $2 \mathrm{mg} / \mathrm{kg} \mathrm{IV}(n=3)$ and 10 $\mathrm{mg} / \mathrm{kg} \mathrm{PO}(n=3)$ dosing in a formulation of $5 \%$ dimethyl sulfoxide (DMSO), 47.5\% poly(ethylene glycol) (PEG) 400, and $47.5 \%$ deionized water with $10 \%$ Tween 80 . The inhibitors were all well tolerated, with no adverse effects observed in any test group allowing for successful readout of all parameters (Table 5).

Assessment in the IV arm showed clearance $(\mathrm{Cl})$ for all compounds well below our set $30 \mathrm{~mL} /(\mathrm{min} \mathrm{kg})$ upper limit, with $11 \mathrm{~b}$ showing the highest rate at $17.1 \mathrm{~mL} /(\mathrm{min} \mathrm{kg})$. The steady-state volume of distribution $\left(V_{\mathrm{ss}}\right)$ was uniformly favorable $\left(V_{\mathrm{ss}}=1-3 \mathrm{~L} / \mathrm{kg}\right)$, with the exception of $14 \mathrm{~g}\left(V_{\mathrm{ss}}=\right.$ $0.48 \mathrm{~L} / \mathrm{kg})$. With $14 \mathrm{~g}$ also registering a half-life $\left(t_{1 / 2}\right)$ under an hour $\left(t_{1 / 2}=0.80 \mathrm{~h}\right)$, a peak serum concentration $\left(C_{\max }\right)$ barely above our set $1 \mu \mathrm{M}$ lower limit $\left(C_{\max }=1.43 \mu \mathrm{M}\right)$, total exposure (area under curve, $\mathrm{AUC}_{\mathrm{inf}}$ ) an order of magnitude lower than that of the other compounds $\left(\mathrm{AUC}_{\mathrm{inf}}=2.97 \mathrm{~h} \cdot \mu \mathrm{M}\right)$, and bioavailability $(F)$ that was grossly suboptimal $(F=7 \%)$, the compound was a distinct outlier. Despite its considerable stability in the MLM/HLM assays and high degree of permeability in the Caco-2 assay, $\mathbf{1 4} \mathrm{g}$ performed so poorly in vivo that we opted to drop the compound from further consideration.

To evaluate the viability of an alternate, DMSO-free vehicle for dosing and its effect on exposure, we opted to convert 6a to both its hydrochloride $(\mathrm{HCl})$ and mesylate $(\mathrm{MsOH})$ salt forms by taking advantage of the 1-position piperazine nitrogen's basicity. Subsequent administration of $6 \mathbf{a} \cdot \mathbf{H C l}$ and $\mathbf{6 a} \cdot \mathbf{M s O H}$ in a formulation of $0.5 \%$ aqueous methylcellulose at $25 \mathrm{mg} / \mathrm{kg}$ PO to NOD SCID mice showed that both increased exposure levels relative to the free base control $6 \mathrm{a}$ at the $0.5,1,2$, and $6 \mathrm{~h}$ time points studied. Although similar in their effect, $\mathbf{6 a} \cdot \mathbf{H C l}$ proved marginally superior and, at the reference time point of $1 \mathrm{~h}$, resulted in a $22 \%$ increase in plasma concentration versus 6 a $\left(C_{\text {plasma }}=9.11 \mu \mathrm{M}\right.$ for $6 \mathrm{a} \cdot \mathbf{H C l}$, while $C_{\text {plasma }}=7.46 \mu \mathrm{M}$ for $\left.6 \mathrm{a}\right)$. Subsequent preparation and screening of $\mathbf{1 1} \mathbf{b} \cdot \mathbf{H C l}$ in the $0.5 \%$ aqueous methylcellulose vehicle produced a comparable improvement in exposure versus the free base $\mathbf{1 1} \mathbf{b}$.

Compounds $6 \mathrm{a}, 11 \mathrm{~b}$, and $14 \mathrm{p}$ were found to be significantly more bioavailable than LDN-214117 $(F=75 \%),{ }^{43}$ with $14 \mathrm{k}-1$ showing more comparable values. The $t_{1 / 2}$ of all compounds (other than 14g) matched or exceeded that of LDN-214117 $\left(t_{1 / 2}=3.91 \mathrm{~h}\right)$, but evaluation of relative $C_{\max }$ and $\mathrm{AUC}_{\mathrm{inf}}$ values is more difficult given the differential dosing across the two trials ( $5 \mathrm{mg} / \mathrm{kg}$ PO in BALB/c mice for LDN-214117). ${ }^{43}$ With PK parameters aligned or superior to those of LDN-214117, it was imperative to determine how well these compounds could potentially function in the CNS.

Determination of BBB penetration was conducted for $\mathbf{6 a}, \mathbf{1 1} \mathbf{b}$, and $14 \mathrm{k}-\mathrm{l}$, opting to remove $14 \mathrm{p}$ from the analysis given its broadly similar PK profile and extra HBA (the phenolic oxygen) we felt could be a liability. At a dose of $10 \mathrm{mg} / \mathrm{kg}$ PO in female CB17 SCID mice $(n=3), 6 \mathbf{a}, \mathbf{1 1} \mathbf{b}$, and $14 \mathbf{k}$ showed exceptional brain-to-plasma ratios $\left(C_{\text {brain }} / C_{\text {plasma }}\right.$ or $\left.B / P\right)$ of $0.90,1.41$, and
0.82, respectively (Table 5). Although not measured under comparable conditions and at the same time point, a $B / P$ of 0.80 $\left(C_{\text {brain }}=10.94 \mu \mathrm{M}\right)$ was reported for LDN-214117 at $2 \mathrm{~h}$ after $25 \mathrm{mg} / \mathrm{kg}$ PO dosing, ${ }^{43}$ making $\mathbf{1 1 b}$ a considerably more CNSpenetrant compound. Even 6a appears to have a modest advantage in $\mathrm{BBB}$ penetration, with $14 \mathrm{k}$ more akin to $\mathrm{LDN}$ 214117. A dose-dependency was observed for the $B / P$ ratios of the two more lipophilic compounds, with increased values observed for both $11 \mathbf{b}\left(B / P=2.03\right.$ with a $\left.C_{\text {brain }}=33 \mu \mathrm{M}\right)$ and $14 \mathrm{k}\left(B / P=1.55\right.$ with a $\left.C_{\text {brain }}=39 \mu \mathrm{M}\right)$ following $100 \mathrm{mg} / \mathrm{kg}$ PO dosing in the same mouse strain $(n=3)$. While these values are exceptional, the efficiency of drug delivery across the BBB is better described by looking at the ratio of the unbound brain concentration $\left(C_{\mathrm{u}, \text { brain }}\right)$ to the unbound plasma concentration $\left(C_{\mathrm{u} \text {,plasma }}\right)$ at steady state, $K_{\mathrm{p}, \mathrm{uu} \cdot}{ }^{62}$ Measuring these concentrations at the $2 \mathrm{~h}$ time point following $1 \mathrm{mg} / \mathrm{kg}$ IV dosing of $6 \mathrm{a}$ in male CD- 1 mice $(n=3)$, we found $C_{\mathrm{u}, \text { brain }}=3.7 \mathrm{nM}$ (3\% of $C_{\text {brain }}=123 \mathrm{nM}$ because $\left.\mathrm{m}-\mathrm{BTB}=97 \%\right)$ and $C_{\mathrm{u} \text {,plasma }}=14 \mathrm{nM}$ $\left(9 \%\right.$ of $C_{\text {plasma }}=156 \mathrm{nM}$ because $\left.\mathrm{m}-\mathrm{PPB}=91 \%\right)$, so $K_{\mathrm{p}, \mathrm{uu}}=0.3$. Although a $K_{\mathrm{p}, \mathrm{uu}}<1$ is indicative of active efflux at the BBB, $K_{\mathrm{p}, \mathrm{uu}}$ $=0.3$ is in-line with a significant number of approved CNS drugs $^{62}$ and, as such, was quite acceptable.

With compound $\mathbf{1 4 1}$ showing relatively low $\mathrm{BBB}$ penetration $(B / P=0.43)$, we opted to evaluate the PK of only $6 \mathbf{a}, \mathbf{1 1} \mathbf{b}$, and $14 \mathrm{k}$ in a second rodent species, dosing male SD rats at $2 \mathrm{mg} / \mathrm{kg}$ $\mathrm{IV}(n=3)$ and $10 \mathrm{mg} / \mathrm{kg} \mathrm{PO}(n=3)$. Notably, $t_{1 / 2}$ values were comparable to or improved (as with $\mathbf{1 1 b}$ ) versus those observed in mice, although $C_{\max } \mathrm{AUC}_{\text {inf }}$ and $F$ metrics were uniformly diminished (Table 5, italicized entries). Compound 6 a emerged as the best performer, retaining both a decent maximum concentration $\left(C_{\max }=1.28 \mu \mathrm{M}\right)$ and bioavailability $(F=96 \%)$.

The evident oral bioavailability across two rodent species prompted us to conduct dose escalation trials with $\mathbf{6 a}, \mathbf{1 1} \mathbf{b}$, and 14k to establish the linearity of $C_{\max }$ and $\mathrm{AUC}_{\mathrm{inf}}$, and administration of the compounds at $10,25,50$, and $100 \mathrm{mg} /$ $\mathrm{kg}$ PO in female CB17 SCID mice ( $n=3$ per treatment) showed a high degree of dose-dependent correlation $\left(r^{2}>0.95\right)$ across both parameters. The absence of any observable behavioral or physical abnormalities in the mice after $24 \mathrm{~h}$ at the highest dose of $100 \mathrm{mg} / \mathrm{kg}$ PO suggested we could test that limit in a prolonged maximum tolerated dose (MTD) study. As we were anticipating the use of 6 a for an in vivo C57BL/6 mouse FOP model to demonstrate $\mathrm{ALK} 2^{\mathrm{R} 206 \mathrm{H}}$ target engagement, we opted to conduct the MTD study in that strain. Oral dosing over 5 days at $25 \mathrm{mg} / \mathrm{kg}$ once a day (QD) and twice a day (BID), $50 \mathrm{mg} / \mathrm{kg}$ $\mathrm{QD}$, and $100 \mathrm{mg} / \mathrm{kg}$ QD showed 6a to be well tolerated with no deaths, body weight loss $(<5 \%)$, or gross pathology observed. Plasma concentrations increased linearly with dose $\left(r^{2}>0.95\right)$, and significant brain exposure was also observed. As with $\mathbf{1 1 b}$ and $14 \mathrm{k}$, an increase in $B / P$ ratios was recorded at the $4 \mathrm{~h}$ time point following the increased doses, with $B / P=1.5,1.8$, and 1.1 for $6 \mathrm{a}$ at 25,50 , and $100 \mathrm{mg} / \mathrm{kg} \mathrm{QD}$, respectively.

In Vitro Biology and In Vivo Mouse Models. Screening of the lead inhibitors $6 \mathrm{a}, 11 \mathrm{~b}$, and $14 \mathrm{k}$ in a panel of patient-derived ACVR1 mutant and WT cell lines showed particularly significant growth inhibition of SU-DIPG-XXI $\left(A C V R 1^{G 328 W}\right)$ and HSJDDIPG-007 (ACVR1 $\left.1^{R 206 H}\right)$ cells, with a $\mathrm{GI}_{50}<250 \mathrm{nM}$ across both lines for all compounds (except 14k against HSJD-DIPG007 with a $\left.\mathrm{GI}_{50}=2.1 \mu \mathrm{M}\right)^{56}$ coupled to an observed decrease in ID1 expression (>50\%). These in vitro results, the aggregate properties of $6 \mathrm{a}, 11 \mathrm{~b}$, and $14 \mathrm{k}$, and their scalable syntheses $(50 \mathrm{~g}$ quantities of each were prepared by GL Chemtec International Ltd. through an in-kind contribution) led us to select these 
Table 6. Alignment of M4K2009, M4K2117, and M4K2163 with the Target Product Profile

\begin{tabular}{|c|c|c|c|c|}
\hline & $\begin{array}{c}\text { Target } \\
\text { Product Profile }\end{array}$ & $\begin{array}{l}\text { M4K2009 } \\
\quad(6 a)\end{array}$ & $\begin{array}{l}\text { M4K2117 } \\
\text { (14k) }\end{array}$ & $\begin{array}{l}\text { M4K2163 } \\
\quad(11 b)\end{array}$ \\
\hline \multicolumn{5}{|l|}{ Physiochemical Properties ${ }^{57}$} \\
\hline Molecular Weight & $<450$ & 419.53 & 432.56 & 407.49 \\
\hline H-bond Donors (HBD) & $<3$ (pref. 1) & 1 & 0 & 1 \\
\hline H-bond Acceptors (HBA) & $<7$ & 6 & 5 & 5 \\
\hline Rotatable Bonds & $<8$ & 6 & 6 & 5 \\
\hline $\operatorname{cLog} \mathrm{P}$ & $<5$ & 3.29 & 4.21 & 3.72 \\
\hline $\mathrm{p} K_{\mathrm{a}}$ & $7.5-10.5$ & 8.60 & 9.79 & 8.60 \\
\hline $\operatorname{tPSA}\left(\AA^{2}\right)$ & $<60-70$ & 55 & 43 & 46 \\
\hline \multicolumn{5}{|l|}{ Potency and Selectivity } \\
\hline $\mathrm{ALK} 2 \mathrm{IC}_{50}(\mathrm{nM})$ & $<20$ & 13 & 7 & 19 \\
\hline $\mathrm{ALK} 2^{\mathrm{G} 328 \mathrm{~V} / \mathrm{R} 206 \mathrm{H} / \mathrm{R} 258 \mathrm{G}} \mathrm{IC}_{50}(\mathrm{nM})$ & $<20$ & $8,9,13$ & - & - \\
\hline $\mathrm{ALK} 5 \mathrm{IC}_{50}(\mathrm{nM})$ & $>1000$ & 2427 & $>5000$ & 2206 \\
\hline ALK2 NanoBRET IC $50(\mathrm{nM})$ & $<100$ & 45 & 29 & 98 \\
\hline $\begin{array}{l}\text { ALK2 } 2^{\mathrm{G} 328 \mathrm{~V} / \mathrm{G} 356 \mathrm{D} / \mathrm{Q} 207 \mathrm{D} / \mathrm{R} 206 \mathrm{H}} \\
\text { NanoBRET IC } \\
50(\mathrm{nM})\end{array}$ & $<100$ & $6,16,7,12$ & - & - \\
\hline ALK5 DLA/ALK2 NanoBRET & $>30$ & 45 & 115 & 74 \\
\hline $\begin{array}{c}\text { DIPG-XXI and -007 Cell Line } \mathrm{GI}_{50} \\
(\mathrm{nM})\end{array}$ & $<500$ & 52,130 & 28,2095 & 214,36 \\
\hline $\begin{array}{l}\text { Kinome-wide Selectivity } \\
\text { (ex ALK1-6) }\end{array}$ & $\begin{array}{l}\text { Numberw/ } />50 \% \\
\text { inhibition } @ 1 \mu \mathrm{M}\end{array}$ & $8 / 368$ & $7 / 368$ & $13 / 368$ \\
\hline \multicolumn{5}{|l|}{ In Vitro ADME } \\
\hline MLM (\%@1 h) & $>50$ & 65 & 56 & 66 \\
\hline HLM (\%@1 h) & $>50$ & 71 & 71 & 84 \\
\hline Caco-2 $P_{\text {app_AB }}\left(\times 10^{-6} \mathrm{~cm} / \mathrm{sec}\right)$ & $>3$ & 5.4 & 9.7 & $1.8^{a}$ \\
\hline Caco-2 BA/AB & $<2.0$ & 1.5 & 0.8 & 2.7 \\
\hline $\mathrm{CYP}$ (7 isoforms) $\mathrm{IC}_{50}(\mu \mathrm{M})$ & $>10$ & $>10$ & $>10$ & $>10^{b}$ \\
\hline $\mathrm{hERG} \mathrm{IC}_{50}(\mu \mathrm{M})$ & $>10$ & 8.3 & 4.8 & 2.5 \\
\hline Ames & Negative & Negative & - & - \\
\hline \multicolumn{5}{|l|}{ In Vivo ADME/PK (Mice) ${ }^{c}$} \\
\hline $\mathrm{Cl}(\mathrm{mL} / \mathrm{min} / \mathrm{kg})$ & $<30$ & 12.7 & 8.90 & 17.1 \\
\hline $\mathrm{V}_{\mathrm{ss}}(\mathrm{L} / \mathrm{kg})$ & $>1$ & 2.05 & 2.44 & 2.77 \\
\hline$t_{1 / 2}(\mathrm{~h})$ & $>3$ & 3.11 & 3.67 & 3.68 \\
\hline$C_{\max }(\mu \mathrm{M})$ & $>1$ & 6.16 & 4.74 & 3.19 \\
\hline$F(\%)$ & $>50$ & 100 & 74 & 95 \\
\hline Dose/Exposure & $\begin{array}{c}\text { Linear @ } 10-100 \\
\mathrm{mg} / \mathrm{kg} \text { PO }(r>0.95)\end{array}$ & Yes & Yes & Yes \\
\hline$C_{\text {brain }} / C_{\text {plasma }}(B / P) @ 4 \mathrm{~h}$ & $>0.5$ & $0.90^{*}$ & 0.82 & 1.41 \\
\hline
\end{tabular}

${ }^{a}$ Low post-assay recovery. ${ }^{b} 2 \mathrm{C} 9 \mathrm{IC}_{50}=7.3 \mu \mathrm{M}$ and $2 \mathrm{C} 19 \mathrm{IC}_{50}=7.7 \mu \mathrm{M} .{ }^{c} 2 \mathrm{mg} / \mathrm{kg}$ IV and $10 \mathrm{mg} / \mathrm{kg}$ PO dosing.

compounds as suitable inhibitors for proof-of-concept in vivo studies in models of FOP and DIPG. Active against ALK2 ${ }^{\text {R206H }}$ in vitro, we anticipated that explicit in vivo target engagement could be demonstrated with 14 day compound dosing in an 
injury-induced heterotopic ossification (HO) Acvr1 $1^{R 206 \mathrm{H} /+}$ mouse model of FOP. ${ }^{63}$ Efficacy in this model would build confidence to dose compounds over 28-56 days in an orthotopic H3.1K27M, ACVR1 ${ }^{R 206 H}$ (Cre, PDGFA infected), ${ }^{27}$ or patient-derived H3.3K27M, $A C V R 1^{R 206 H}$ HSJD-DIPG-007 tumor xenograft ${ }^{43}$ mouse model of DIPG. Full disclosure of the in vitro biology and in vivo model outcomes is beyond the scope of this publication and will be done under separate cover (see the Supporting Information, Note S2).

\section{CONCLUSIONS}

With the recent identification of ALK2 as a suitable target for therapeutic intervention in the treatment of DIPG, inhibitors from several chemical classes have been reported (Figure 1). One of the most well characterized, LDN-214117, demonstrated significant efficacy in an orthotopic mouse model of the disease and provided the basis for the further development of related inhibitors. ${ }^{43}$ In this work, using LDN-214117 as a lead compound, we expanded the SAR around the 3,5-diphenylpyridine inhibitor class to optimize potency against ALK2, increase selectivity over important off-targets such as ALK5, and produce a set of preclinical compounds with superior $\mathrm{ADME}$ and $\mathrm{PK}$ properties characteristic of a viable CNS drug. With the development of compound $\mathbf{6 a}$, we found that incorporation of a C-4 position methyl group on the pyridine core allowed for greater potency against ALK2 in both biochemical and cellbased assays while simultaneously conferring increased selectivity over ALK5. The compound also exhibited remarkable kinome-wide selectivity, little activity against other (receptor) off-targets, no significant CYP inhibition, and a manageable degree of activity against the hERG potassium channel. Subsequent structural modifications at the C-3 and C-5 positions gave rise to compounds $11 \mathbf{b}$ and $14 \mathbf{k}$, which not only possessed the favorable PK characteristics evident in 6a but also demonstrated the superior levels of $\mathrm{BBB}$ penetration required of a CNS drug candidate. The aggregate properties of 6a, 11b, and 14k prompted us to select these compounds for further preclinical development as advanced candidates M4K2009, M4K2163, and M4K2117, respectively. All three inhibitors satisfied the criteria of our target product profile (TPP), with only hERG potassium channel inhibition being the exception (Table 6).

Employing an open science model, we were able to compress the development timeline for these analogs by bringing together chemistry and biological screening capacity. Extensive evaluation of M4K2009, M4K2117, and M4K2163 in vitro against patient-derived DIPG cell lines and in vivo proof-of-concept studies in orthotopic mouse models of DIPG will be conducted in an equally open manner, with complete results to be reported at a later date.

\section{EXPERIMENTAL SECTION}

Chemistry. All reagents were purchased from commercial vendors and used without further purification. Volatiles were removed under reduced pressure by rotary evaporation or using the V-10 solvent evaporator system from Biotage. Very high boiling point $(6000 \mathrm{rpm}, 0$ mbar, $\left.56{ }^{\circ} \mathrm{C}\right)$, mixed volatile $\left(7000 \mathrm{rpm}, 30 \mathrm{mbar}, 36^{\circ} \mathrm{C}\right)$, and volatile $\left(6000 \mathrm{rpm}, 30 \mathrm{mbar}, 36^{\circ} \mathrm{C}\right.$ ) methods were used to evaporate solvents. The yields given refer to chromatographically purified and spectroscopically pure compounds, unless stated otherwise. Compounds were purified using a Biotage Isolera One system by normal phase chromatography using Biotage SNAP KP-Sil or Sfär Silica D columns (part no. FSKO-1107/FSRD-0445) or by reverse-phase chromatography using Biotage SNAP KP-C18-HS or Sfär C18 D columns (part no. FSLO-1118/FSUD-040). If additional purification was required, compounds were purified by solid-phase extraction (SPE) using Biotage Isolute Flash SCX-2 cation exchange cartridges (part nos. 532-0050-C and 456-0200-D). Products were washed with two cartridge volumes of $\mathrm{MeOH}$ and eluted with a solution of $\mathrm{MeOH}$ and $\mathrm{NH}_{4} \mathrm{OH}(9: 1 \mathrm{v} / \mathrm{v})$. Preparative chromatography was carried out using a Waters 2767 injector with a collector attached to PDA UV-vis and SQD mass detectors. An XSelect CSH Prep C18 $5 \mu \mathrm{m}$ OBD $19 \mathrm{~mm}$ $\times 100 \mathrm{~mm}$ (part no. 186005421) or an Xselect CSH Prep C18 $5 \mu \mathrm{m} 10$ $\mathrm{mm} \times 100 \mathrm{~mm}$ (part no. 186005415) column was used for purification. Final compounds were dried using the Labconco Benchtop FreeZoneTM Freeze-Dry System (4.5 L model). ${ }^{1} \mathrm{H}$ NMRs were recorded on a Bruker Avance-III $500 \mathrm{MHz}$ spectrometer at ambient temperature. Residual protons of $\mathrm{CDCl}_{3}, \mathrm{DMSO}-d_{6}$, and $\mathrm{CD}_{3} \mathrm{OD}$ solvents were used as internal references. Spectral data are reported as follows: chemical shift ( $\delta$ in ppm), multiplicity (br, broad; s, singlet; d, doublet; dd, doublet of doublets; $\mathrm{m}$, multiplet), coupling constants $(\mathrm{J}$ in $\mathrm{Hz}$ ), and proton integration. Compound purity was determined by UV absorbance at $254 \mathrm{~nm}$ during tandem liquid chromatography/mass spectrometry (LCMS) using a Waters Acquity separation module. All final compounds had a purity of $\geq 95 \%$ as determined using this method. Low-resolution mass spectrometry was conducted in the positive ion mode using a Waters Acquity SQD mass spectrometer (electrospray ionization source) fitted with a PDA detector. Mobile phase A consisted of $0.1 \%$ formic acid in water, while mobile phase B consisted of $0.1 \%$ formic acid in acetonitrile. One of three types of columns were used; column 1: Acquity UPLC CSH C18 $(2.1 \mathrm{~mm} \times 50$ $\mathrm{mm}, 130 \AA$ A $1.7 \mu \mathrm{m}$. part no. 186005296); column 2: Acquity UPLC BEH C8 (2.1 mm $\times 50 \mathrm{~mm}, 130 \AA, 1.7 \mu \mathrm{m}$. part no. 186002877); or column 3: Acquity UPLC HSS T3 $(2.1 \mathrm{~mm} \times 50 \mathrm{~mm}, 100 \AA \AA, 1.8 \mu \mathrm{m}$. part no. 186003538). For columns 1 and 2, the gradient went from 90 to $5 \%$ mobile phase A over $1.8 \mathrm{~min}$, maintained at $5 \%$ for $0.5 \mathrm{~min}$, then increased to $90 \%$ over $0.2 \mathrm{~min}$ for a total run time of $3 \mathrm{~min}$. For column 3 , the gradient went from 98 to $5 \%$ mobile phase A over $1.8 \mathrm{~min}$, maintained at $5 \%$ for $0.5 \mathrm{~min}$, then increased to $98 \%$ over $0.2 \mathrm{~min}$ for a total run time of $3 \mathrm{~min}$. The flow rate was $0.4 \mathrm{~mL} / \mathrm{min}$ throughout both runs. All columns were used with the temperature maintained at $25{ }^{\circ} \mathrm{C}$. High-resolution mass spectrometry was conducted using a Waters Synapt G2-S quadrupole-time-of-flight (Q-TOF) hybrid mass spectrometer system coupled with an Acquity ultraperformance liquid chromatography (UPLC) I-Class system. Chromatographic separations were carried out on an Acquity UPLC HSS T3 $(2.1 \mathrm{~mm} \times 100$ $\mathrm{mm}, 100 \AA ̊, 1.8 \mu \mathrm{m}$, part no. 186003539 ). The mobile phases were $0.1 \%$ formic acid in water (solvent $\mathrm{A}$ ) and $0.1 \%$ formic acid in acetonitrile (solvent B). Leucine Enkephalin was used as the lock-mass. MassLynx 4.1 was used for data analysis.

General Procedure A for the Synthesis of Intermediates $3 a, 3 d-e$, and $3 \boldsymbol{g}-\boldsymbol{i}$. To a solution of 3-bromo-5-chloro-pyridine $1 \mathrm{a}, 1 \mathrm{~d}-\mathrm{e}$, or $1 \mathrm{~g}-\mathbf{i}(0.484 \mathrm{mmol}), 3,4,5$-trimethoxyphenylboronic acid (2) (103 mg, $0.484 \mathrm{mmol})$, and $\mathrm{Na}_{2} \mathrm{CO}_{3}(205 \mathrm{mg}, 1.94 \mathrm{mmol})$ in DMF $(2.2 \mathrm{~mL})$ and water $(0.6 \mathrm{~mL})$ at room temperature was added [1,12-bis(diphenylphosphino)ferrocene]dichloropalladium(II)·DCM complex $(20 \mathrm{mg}, 0.024 \mathrm{mmol})$. After heating the resulting mixture at $100^{\circ} \mathrm{C}$ for $16 \mathrm{~h}$, it was cooled down to room temperature and diluted with water $(40 \mathrm{~mL})$ and the aqueous layer was extracted with EtOAc $(3 \times 20 \mathrm{~mL})$. The combined organic extracts were dried with anhydrous $\mathrm{Na}_{2} \mathrm{SO}_{4}$, filtered, and concentrated under reduced pressure. This crude material was purified by chromatography on silica $(10-100 \%$ EtOAc in hexanes) to afford intermediate $\mathbf{3 a}, \mathbf{3 e}, \mathbf{3} \mathbf{h}-\mathbf{i}$ (all in $>70 \%$ yield), $\mathbf{3 d}$, or $3 \mathrm{~g}$ (both in $\sim 50 \%$ yield) as a powder. The identity of all products was confirmed by low-resolution mass spectrometry (LRMS) before use in the subsequent synthetic step.

General Procedure B for the Synthesis of Intermediates $3 b-c$ and 3f. To a solution of 3,5-dichloropyridine $1 \mathrm{~b}-\mathrm{c}$ or $1 \mathrm{f}(0.484 \mathrm{mmol})$, 3,4,5-trimethoxyphenylboronic acid (2) (103 $\mathrm{mg}, 0.484 \mathrm{mmol})$, and XPhos Pd G2 (19 mg, $0.024 \mathrm{mmol})$ in butanol $(3 \mathrm{~mL})$ at room temperature was added $\mathrm{K}_{3} \mathrm{PO}_{4}(1.3 \mathrm{M}$ solution in water) $(0.748 \mathrm{~mL}$, $0.973 \mathrm{mmol}$ ). After heating the resulting mixture at $100{ }^{\circ} \mathrm{C}$ for $4 \mathrm{~h}$, it was cooled down to room temperature and diluted with water $(40 \mathrm{~mL})$ and the aqueous layer was extracted with EtOAc $(3 \times 20 \mathrm{~mL})$. The 
combined organic extracts were dried with anhydrous $\mathrm{Na}_{2} \mathrm{SO}_{4}$, filtered, and concentrated under reduced pressure. This crude material was purified by chromatography on silica (10-100\% EtOAc in hexanes) to afford intermediate $\mathbf{3 b}-\mathbf{c}$ or $\mathbf{3} \mathbf{f}$ (all in $\sim 50 \%$ yield) as a powder. The identity of all products was confirmed by LRMS before use in the subsequent synthetic step.

Procedure for the Synthesis of Intermediates $5 \mathbf{a}-\boldsymbol{i}$. General procedure B, with tert-butyl 4-[4-(4,4,5,5-tetramethyl-1,3,2-dioxaborolan-2-yl)phenyl]piperazine-1-carboxylate (4) replacing 3,4,5-trimethoxyphenylboronic acid (2), was used to synthesize intermediates 5ai (all in $>70 \%$ yield) as a powder from intermediates $3 \mathbf{a}-\mathbf{i}$. The identity of all products was confirmed by LRMS before use in the subsequent synthetic step.

General Procedure C for the Synthesis of Compounds $6 a-i$. To a solution of intermediates $\mathbf{5 a}-\mathbf{i}(0.230 \mathrm{mmol})$ in methanol $(\mathrm{MeOH})(4$ $\mathrm{mL})$ at room temperature was added hydrogen chloride solution $(4.0 \mathrm{M}$ in dioxane $)(0.29 \mathrm{~mL}, 1.16 \mathrm{mmol})$. The resulting mixture was stirred for $30 \mathrm{~min}$ prior to removal of all solvents under reduced pressure, dissolution of the residue in a minimal amount of $\mathrm{MeOH}$, and purification by SPE to afford compounds $6 \mathbf{a}-\mathbf{i}$ (all in $>95 \%$ yield) as a powder.

1-(4-(4-Methyl-5-(3,4,5-trimethoxyphenyl)pyridin-3-yl)phenyl)piperazine (6a) (M4K2009). ${ }^{1} \mathrm{H}$ NMR $\left(500 \mathrm{MHz}, \mathrm{MeOD}-d_{4}\right) \delta 8.32(\mathrm{~s}$, $1 \mathrm{H}), 8.31(\mathrm{~s}, 1 \mathrm{H}), 7.33(\mathrm{~d}, J=8.9 \mathrm{~Hz}, 2 \mathrm{H}), 7.12(\mathrm{~d}, J=8.8 \mathrm{~Hz}, 2 \mathrm{H})$, $6.70(\mathrm{~s}, 2 \mathrm{H}), 3.90(\mathrm{~s}, 6 \mathrm{H}), 3.86(\mathrm{~s}, 3 \mathrm{H}), 3.28-3.24(\mathrm{~m}, 4 \mathrm{H}), 3.07-3.03$ (m, 4H), $2.26(\mathrm{~s}, 3 \mathrm{H})$. HRMS (ESI) for $\mathrm{C}_{25} \mathrm{H}_{30} \mathrm{~N}_{3} \mathrm{O}_{3}[\mathrm{M}+\mathrm{H}]^{+} \mathrm{m} / z$ : calcd, 420.2287; found, 420.2279 .

1-(4-(4-Ethyl-5-(3,4,5-trimethoxyphenyl)pyridin-3-yl)phenyl)piperazine (6b). ${ }^{1} \mathrm{H}$ NMR $\left(500 \mathrm{MHz}, \mathrm{MeOD}-d_{4}\right) \delta 8.29(\mathrm{~s}, 1 \mathrm{H}), 8.25$ $(\mathrm{s}, 1 \mathrm{H}), 7.31(\mathrm{~d}, J=8.5 \mathrm{~Hz}, 2 \mathrm{H}), 7.14(\mathrm{~d}, J=8.5 \mathrm{~Hz}, 2 \mathrm{H}), 6.68(\mathrm{~s}, 2 \mathrm{H})$, $3.88(\mathrm{~s}, 6 \mathrm{H}), 3.84(\mathrm{~s}, 3 \mathrm{H}), 3.40-3.36(\mathrm{~m}, 4 \mathrm{H}), 3.25-3.21(\mathrm{~m}, 4 \mathrm{H})$, $2.75-2.68(\mathrm{~m}, 2 \mathrm{H}), 0.82(\mathrm{t}, J=7.5 \mathrm{~Hz}, 3 \mathrm{H})$. HRMS (ESI) for $\mathrm{C}_{26} \mathrm{H}_{32} \mathrm{~N}_{3} \mathrm{O}_{3}[\mathrm{M}+\mathrm{H}]^{+} \mathrm{m} / z$ : calcd, 434.2444; found, 434.2436.

1-(4-(4-Cyclopropyl-5-(3,4,5-trimethoxyphenyl)pyridin-3-yl)phenyl)piperazine (6c). ${ }^{1} \mathrm{H}$ NMR (500 MHz, MeOD- $\left.d_{4}\right) \delta 8.44$ (s, $1 \mathrm{H}), 8.42(\mathrm{~s}, 1 \mathrm{H}), 7.52(\mathrm{~d}, J=8.5 \mathrm{~Hz}, 2 \mathrm{H}), 7.19(\mathrm{~d}, J=8.5 \mathrm{~Hz}, 2 \mathrm{H})$, $6.89(\mathrm{~s}, 2 \mathrm{H}), 3.98(\mathrm{~s}, 6 \mathrm{H}), 3.93(\mathrm{~s}, 3 \mathrm{H}), 3.37(\mathrm{~d}, J=4.9 \mathrm{~Hz}, 4 \mathrm{H}), 3.21-$ $3.14(\mathrm{~m}, 4 \mathrm{H}), 2.32-2.20(\mathrm{~m}, 1 \mathrm{H}), 0.63-0.58(\mathrm{br} \mathrm{m}, 2 \mathrm{H}), 0.05-0.00$ (br m, 2H). HRMS (ESI) for $\mathrm{C}_{27} \mathrm{H}_{32} \mathrm{~N}_{3} \mathrm{O}_{3}[\mathrm{M}+\mathrm{H}]^{+} \mathrm{m} / z$ : calcd, 446.2444; found, 446.2437.

1-(4-(4-Methoxy-5-(3,4,5-trimethoxyphenyl)pyridin-3-yl)phenyl)-

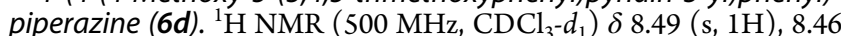
$(\mathrm{s}, 1 \mathrm{H}), 7.49(\mathrm{~d}, J=8.8 \mathrm{~Hz}, 2 \mathrm{H}), 7.02(\mathrm{~d}, J=8.8 \mathrm{~Hz}, 2 \mathrm{H}), 6.79(\mathrm{~s}, 2 \mathrm{H})$, 3.94-3.88 (m, 9H), $3.39(\mathrm{~s}, 3 \mathrm{H}), 3.28-3.21(\mathrm{~m}, 4 \mathrm{H}), 3.12-3.04(\mathrm{~m}$, $4 \mathrm{H}$ ). HRMS (ESI) for $\mathrm{C}_{25} \mathrm{H}_{30} \mathrm{~N}_{3} \mathrm{O}_{4}[\mathrm{M}+\mathrm{H}]^{+} \mathrm{m} / z$ : calcd, 436.2236; found, 436.2234.

3-(4-(Piperazin-1-yl)phenyl)-5-(3,4,5-trimethoxyphenyl)pyridin4-amine (6e). ${ }^{1} \mathrm{H}$ NMR $\left(500 \mathrm{MHz}, \mathrm{MeOD}-d_{4}\right) \delta 7.85(\mathrm{~s}, 1 \mathrm{H}), 7.82(\mathrm{~s}$, $1 \mathrm{H}), 7.25(\mathrm{~d}, J=8.7 \mathrm{~Hz}, 2 \mathrm{H}), 7.01(\mathrm{~d}, J=8.7 \mathrm{~Hz}, 2 \mathrm{H}), 6.64(\mathrm{~s}, 2 \mathrm{H})$, $3.78(\mathrm{~s}, 6 \mathrm{H}), 3.72(\mathrm{~s}, 3 \mathrm{H}), 3.15-3.08(\mathrm{~m}, 4 \mathrm{H}), 2.94-2.87(\mathrm{~m}, 4 \mathrm{H})$. HRMS (ESI) for $\mathrm{C}_{24} \mathrm{H}_{29} \mathrm{~N}_{4} \mathrm{O}_{3}[\mathrm{M}+\mathrm{H}]^{+} \mathrm{m} / z$ : calcd, 421.2240; found, 421.2235 .

1-(4-(4-Fluoro-5-(3,4,5-trimethoxyphenyl)pyridin-3-yl)phenyl)piperazine (6f). ${ }^{1} \mathrm{H} \mathrm{NMR}\left(500 \mathrm{MHz}, \mathrm{MeOD}-d_{4}\right) \delta 8.59$ (d, $J=5.4 \mathrm{~Hz}$, $1 \mathrm{H}), 8.57(\mathrm{~d}, J=5.4 \mathrm{~Hz}, 1 \mathrm{H}), 7.57(\mathrm{~d}, J=7.8 \mathrm{~Hz}, 2 \mathrm{H}), 7.14(\mathrm{~d}, J=8.8$ $\mathrm{Hz}, 2 \mathrm{H}), 6.91(\mathrm{~s}, 2 \mathrm{H}), 3.91(\mathrm{~s}, 6 \mathrm{H}), 3.85(\mathrm{~s}, 3 \mathrm{H}), 3.40-3.36(\mathrm{~m}, 4 \mathrm{H})$, 3.22-3.16 (m, 4H). HRMS (ESI) for $\mathrm{C}_{24} \mathrm{H}_{27} \mathrm{FN}_{3} \mathrm{O}_{3}[\mathrm{M}+\mathrm{H}]^{+} \mathrm{m} / z$ : calcd, 424.2036; found, 424.2025 .

1-(4-(4-Chloro-5-(3,4,5-trimethoxyphenyl)pyridin-3-yl)phenyl)piperazine (6g). ${ }^{1} \mathrm{H}$ NMR (500 MHz, DMSO-d $) \delta 8.52(\mathrm{~s}, 1 \mathrm{H}), 8.48$ $(\mathrm{s}, 1 \mathrm{H}), 7.39(\mathrm{~d}, J=8.2 \mathrm{~Hz}, 2 \mathrm{H}), 7.03(\mathrm{~d}, J=8.3 \mathrm{~Hz}, 2 \mathrm{H}), 6.82(\mathrm{~s}, 2 \mathrm{H})$, $3.82(\mathrm{~s}, 6 \mathrm{H}), 3.72(\mathrm{~s}, 3 \mathrm{H}), 3.14$ (br s, 4H), 2.85 (br s, 4H). HRMS (ESI) for $\mathrm{C}_{24} \mathrm{H}_{27} \mathrm{ClN}_{3} \mathrm{O}_{3}[\mathrm{M}+\mathrm{H}]^{+} \mathrm{m} / z$ : calcd, 440.1741 ; found, 440.1728 .

1-(4-(4-(Trifluoromethyl)-5-(3,4,5-trimethoxyphenyl)pyridin-3yl)phenyl)piperazine (6h). ${ }^{1} \mathrm{H}$ NMR $\left(500 \mathrm{MHz}, \mathrm{MeOD}-d_{4}\right) \delta 8.60(\mathrm{~s}$, $1 \mathrm{H}), 8.56(\mathrm{~s}, 1 \mathrm{H}), 7.33(\mathrm{~d}, J=8.7 \mathrm{~Hz}, 2 \mathrm{H}), 7.09(\mathrm{~d}, J=8.8 \mathrm{~Hz}, 2 \mathrm{H})$, $6.74(\mathrm{~s}, 2 \mathrm{H}), 3.89(\mathrm{~s}, 6 \mathrm{H}), 3.85(\mathrm{~s}, 3 \mathrm{H}), 3.28-3.24(\mathrm{~m} .4 \mathrm{H}), 3.05-3.01$ (m, 4H). HRMS (ESI) for $\mathrm{C}_{25} \mathrm{H}_{27} \mathrm{~F}_{3} \mathrm{~N}_{3} \mathrm{O}_{3}[\mathrm{M}+\mathrm{H}]^{+} \mathrm{m} / z$ : calcd, 474.2005; found, 474.2000 .

3-(4-(Piperazin-1-yl)phenyl)-5-(3,4,5-trimethoxyphenyl)isonicotinonitrile (6i). ${ }^{1} \mathrm{H}$ NMR $\left(500 \mathrm{MHz}, \mathrm{MeOD}-d_{4}\right) \delta 8.76(\mathrm{~s}, 1 \mathrm{H})$, $8.75(\mathrm{~s}, 1 \mathrm{H}), 7.62(\mathrm{~d}, J=8.7 \mathrm{~Hz}, 2 \mathrm{H}), 7.16(\mathrm{~d}, J=8.7 \mathrm{~Hz}, 2 \mathrm{H}), 7.00(\mathrm{~s}$, $2 \mathrm{H}), 3.95(\mathrm{~s}, 6 \mathrm{H}), 3.88(\mathrm{~s}, 3 \mathrm{H}), 3.35-331(\mathrm{~m}, 4 \mathrm{H}), 3.07-3.03(\mathrm{~m}$, $4 \mathrm{H}$ ). HRMS (ESI) for $\mathrm{C}_{25} \mathrm{H}_{27} \mathrm{~N}_{4} \mathrm{O}_{3}[\mathrm{M}+\mathrm{H}]^{+} \mathrm{m} / z$ : calcd, 431.2083; found, 431.2074 .

Procedure for the Synthesis of Intermediates 7a-b. General procedure A, with tert-butyl 4-[4-(4,4,5,5-tetramethyl-1,3,2-dioxaborolan-2-yl)phenyl]piperazine-1-carboxylate (4) replacing 3,4,5-trimethoxyphenylboronic acid (2), was used to synthesize intermediates $7 \mathbf{a}-$ $\mathbf{b}$ (both in $>70 \%$ yield) as a powder from 3-bromo-5-chloro-pyridine $\mathbf{1 a}$ or 1i. The identity of both products was confirmed by LRMS before use in the subsequent synthetic step.

Procedure for the Synthesis of Intermediates 10a-c. General procedure B, with either 3,5-dimethoxyphenylboronic acid (8) or (4fluoro-3,5-dimethoxyphenyl)boronic acid (9) replacing 3,4,5-trimethoxyphenylboronic acid (2), was used to synthesize intermediates $10 \mathbf{a}-\mathbf{c}$ (all in $>70 \%$ yield) as a powder from intermediates $7 \mathbf{a}-\mathbf{b}$. The identity of all products was confirmed by LRMS before use in the subsequent synthetic step.

Procedure for the Synthesis of Compounds 11a-c. General procedure $\mathrm{C}$, with intermediates $10 \mathbf{a}-\mathbf{c}$ replacing intermediates $\mathbf{5 a}-\mathbf{i}$, was used to synthesize compounds $11 a-c$ (all in $>95 \%$ yield) as a powder.

1-(4-(5-(3,5-Dimethoxyphenyl)-4-methylpyridin-3-yl)phenyl)piperazine (11a). ${ }^{1} \mathrm{H}$ NMR $\left(500 \mathrm{MHz}, \mathrm{MeOD}-d_{4}\right) \delta 8.18(\mathrm{~s}, 1 \mathrm{H}), 8.16$ $(\mathrm{s}, 1 \mathrm{H}), 7.20(\mathrm{~d}, J=8.7 \mathrm{~Hz}, 2 \mathrm{H}), 6.99(\mathrm{~d}, J=8.7 \mathrm{~Hz}, 2 \mathrm{H}), 6.45(\mathrm{t}, J=2.1$ $\mathrm{Hz}, 1 \mathrm{H}), 6.41(\mathrm{~d}, J=2.2 \mathrm{~Hz}, 2 \mathrm{H}), 3.72(\mathrm{~s}, 6 \mathrm{H}), 3.20-3.15(\mathrm{~m}, 4 \mathrm{H})$ 3.04-2.93 (m, 4H), $2.10(\mathrm{~s}, 3 \mathrm{H})$. HRMS (ESI) for $\mathrm{C}_{24} \mathrm{H}_{28} \mathrm{~N}_{3} \mathrm{O}_{2}[\mathrm{M}+$ $\mathrm{H}]^{+} \mathrm{m} / z$ : calcd, 390.2182; found, 390.2171 .

1-(4-(5-(4-Fluoro-3,5-dimethoxyphenyl)-4-methylpyridin-3-yl)phenyl)piperazine (11b) (M4K2163). ${ }^{1} \mathrm{H}$ NMR $\left(500 \mathrm{MHz}, \mathrm{MeOD}-d_{4}\right)$ $\delta 8.32(\mathrm{~s}, 2 \mathrm{H}), 7.32(\mathrm{~d}, J=8.8 \mathrm{~Hz}, 2 \mathrm{H}), 7.12(\mathrm{~d}, J=8.8 \mathrm{~Hz}, 2 \mathrm{H}), 6.75(\mathrm{~d}$, $J=7.0 \mathrm{~Hz}, 2 \mathrm{H}), 3.92(\mathrm{~s}, 6 \mathrm{H}), 3.28-3.23(\mathrm{~m}, 4 \mathrm{H}), 3.07-3.02(\mathrm{~m}, 4 \mathrm{H})$, $2.25(\mathrm{~s}, 3 \mathrm{H})$. HRMS (ESI) for $\mathrm{C}_{24} \mathrm{H}_{27} \mathrm{FN}_{3} \mathrm{O}_{2}[\mathrm{M}+\mathrm{H}]^{+} \mathrm{m} / z$ : calcd, 408.2087; found, 408.2075.

3-(4-Fluoro-3,5-dimethoxyphenyl)-5-(4-(piperazin-1-yl)phenyl)isonicotinonitrile (11c). ${ }^{1} \mathrm{H}$ NMR $\left(500 \mathrm{MHz}, \mathrm{MeOD}-d_{4}\right) \delta 8.65(\mathrm{~s}$, $1 \mathrm{H}), 8.63(\mathrm{~s}, 1 \mathrm{H}), 7.51(\mathrm{~d}, J=8.8 \mathrm{~Hz}, 2 \mathrm{H}), 7.06(\mathrm{~s}, 1 \mathrm{H}), 7.04(\mathrm{~s}, 1 \mathrm{H})$, $6.93(\mathrm{~d}, J=6.9 \mathrm{~Hz}, 2 \mathrm{H}), 3.84(\mathrm{~s}, 6 \mathrm{H}), 3.26-3.21(\mathrm{~m}, 4 \mathrm{H}), 3.01-2.96$ (m, 4H). HRMS (ESI) for $\mathrm{C}_{24} \mathrm{H}_{24} \mathrm{FN}_{4} \mathrm{O}_{2}[\mathrm{M}+\mathrm{H}]^{+} \mathrm{m} / z$ : calcd, 419.1883; found, 419.1874.

Procedure for the Synthesis of Intermediates 13c, 13j, 13I, 13n and $13 p$ and Compounds $14 a-b, 14 h-i, 14 k, 14 m, 140$, and $14 q$. General procedure $B$, with a $4-\left(R_{1}\right)$ phenylboronic acid/pinacol ester $12 \mathrm{a}-\mathrm{c}$ or $\mathbf{1 2 h}-\mathbf{q}$ replacing 3,4,5-trimethoxyphenylboronic acid (2), was used to synthesize intermediates $13 c, 13 j, 131,13 n$, or $13 p$ and compound $14 a-b, 14 h-i, 14 k, 14 m, 14 o$, or $14 q$ (all in $>70 \%$ yield $)$ as a powder from intermediate $3 a$.

Procedure for the Synthesis of Compounds 14c, 14j, 14l, 14n, and $14 p$. General procedure $C$, with intermediate $13 c, 13 j, 131,13 n$, or $13 p$ replacing intermediates $5 \mathbf{a}-\mathbf{i}$, was used to synthesize compound $\mathbf{1 4 c}$, $14 \mathbf{j}, 141,14 \mathbf{n}$, or $14 \mathbf{p}$ (all in $>95 \%$ yield) as a powder.

Procedure for the Synthesis of Compound 14d. To a solution of compound 6a (M4K2009) (40 mg, $0.095 \mathrm{mmol}$ ) and 2-fluoroethyl tosylate $(25 \mathrm{mg}, 0.114 \mathrm{mmol})$ in acetonitrile $(1 \mathrm{~mL})$ at room temperature was added TEA $(19 \mathrm{mg}, 0.190 \mathrm{mmol})$. After heating the resulting mixture at $100{ }^{\circ} \mathrm{C}$ for $16 \mathrm{~h}$, it was cooled down to room temperature and diluted with water $(30 \mathrm{~mL})$ and the aqueous layer was extracted with EtOAc $(3 \times 20 \mathrm{~mL})$. The combined organic extracts were dried with anhydrous $\mathrm{Na}_{2} \mathrm{SO}_{4}$, filtered, and concentrated under reduced pressure. This crude material was purified by chromatography on silica (0-20\% $\mathrm{MeOH}$ in EtOAc) to afford compound 14d (65\% yield) as a powder.

General Procedure for the Synthesis of Compounds $14 \boldsymbol{e}-\boldsymbol{g}$. To a solution of compound 6a (M4K2009) $(40 \mathrm{mg}, 0.095 \mathrm{mmol})$ in THF (4 $\mathrm{mL}$ ) at room temperature was added acetyl chloride (for 14e), dimethylcarbamyl chloride (for $\mathbf{1 4 f}$ ), or methanesulfonyl chloride (for $14 \mathrm{~g})(0.114 \mathrm{mmol})$ and DIPEA $(25 \mathrm{mg}, 0.190 \mathrm{mmol})$. After stirring the resulting mixture for $1 \mathrm{~h}$, it was diluted with water $(30 \mathrm{~mL})$ and the aqueous layer was extracted with EtOAc $(3 \times 20 \mathrm{~mL})$. The combined organic extracts were dried with anhydrous $\mathrm{Na}_{2} \mathrm{SO}_{4}$, filtered, and 
concentrated under reduced pressure. This crude material was purified by chromatography on silica (0-100\% EtOAc in hexanes) to afford compounds $14 \mathbf{e}-\mathbf{g}$ (all in $>80 \%$ yield) as a powder.

1-Methyl-4-(4-(4-methyl-5-(3,4,5-trimethoxyphenyl)pyridin-3$y$ l)phenyl)piperazine (14a). ${ }^{1} \mathrm{H}$ NMR $\left(500 \mathrm{MHz}, \mathrm{MeOD}-d_{4}\right) \delta 8.30$ $(\mathrm{d}, J=2.7 \mathrm{~Hz}, 2 \mathrm{H}), 7.31(\mathrm{t}, J=5.7 \mathrm{~Hz}, 2 \mathrm{H}), 7.11(\mathrm{~d}, J=8.8 \mathrm{~Hz}, 2 \mathrm{H})$, $6.69(\mathrm{~s}, 2 \mathrm{H}), 3.89(\mathrm{~s}, 6 \mathrm{H}), 3.84(\mathrm{~s}, 3 \mathrm{H}), 3.33-3.29(\mathrm{~m}, 4 \mathrm{H}), 2.72-2.67$ $(\mathrm{m}, 4 \mathrm{H}), 2.41(\mathrm{~s}, 3 \mathrm{H}), 2.24(\mathrm{~s}, 3 \mathrm{H})$. HRMS (ESI) for $\mathrm{C}_{26} \mathrm{H}_{32} \mathrm{~N}_{3} \mathrm{O}_{3}[\mathrm{M}$ $+\mathrm{H}]^{+} \mathrm{m} / z$ : calcd, 434.2444; found, 434.2432.

1-Isopropyl-4-(4-(4-methyl-5-(3,4,5-trimethoxyphenyl)pyridin-3yl)phenyl)piperazine (14b). ${ }^{1} \mathrm{H}$ NMR $\left(500 \mathrm{MHz}, \mathrm{MeOD}-d_{4}\right) \delta 8.31$ (s, $2 \mathrm{H}), 7.32(\mathrm{~d}, J=8.7 \mathrm{~Hz}, 2 \mathrm{H}), 7.11(\mathrm{~d}, J=8.7 \mathrm{~Hz}, 2 \mathrm{H}), 6.69(\mathrm{~s}, 2 \mathrm{H})$, $3.89(\mathrm{~s}, 6 \mathrm{H}), 3.84(\mathrm{~s}, 3 \mathrm{H}), 3.33-3.29(\mathrm{~m}, 4 \mathrm{H}), 2.84-2.68(\mathrm{~m}, 5 \mathrm{H})$, $2.25(\mathrm{~s}, 3 \mathrm{H}), 1.17(\mathrm{~d}, J=6.5 \mathrm{~Hz}, 6 \mathrm{H})$. HRMS (ESI) for $\mathrm{C}_{28} \mathrm{H}_{36} \mathrm{~N}_{3} \mathrm{O}_{3}$ $[\mathrm{M}+\mathrm{H}]^{+} \mathrm{m} / z$ : calcd, 462.2757; found, 462.2746.

(3S,5R)-3,5-Dimethyl-1-(4-(4-methyl-5-(3,4,5-trimethoxyphenyl)pyridin-3-yl)phenyl)piperazine (14c). ${ }^{1} \mathrm{H}$ NMR (500 MHz, DMSO$\left.d_{6}\right) \delta 8.35(\mathrm{~s}, 1 \mathrm{H}), 8.32(\mathrm{~s}, 1 \mathrm{H}), 7.28(\mathrm{br} \mathrm{d}, J=8.6 \mathrm{~Hz}, 2 \mathrm{H}), 7.02(\mathrm{br} \mathrm{d}, J$ $=8.7 \mathrm{~Hz}, 2 \mathrm{H}), 6.72(\mathrm{~s}, 2 \mathrm{H}), 3.81(\mathrm{~s}, 6 \mathrm{H}), 3.72(\mathrm{~s}, 3 \mathrm{H}), 3.61(\mathrm{br} \mathrm{d}, J=$ $10.8 \mathrm{~Hz}, 2 \mathrm{H}), 2.80-2.90(\mathrm{~m}, 2 \mathrm{H}), 2.10-2.20(\mathrm{~m}, 6 \mathrm{H}), 1.04(\mathrm{~d}, J=6.2$ $\mathrm{Hz}, 6 \mathrm{H})$. HRMS (ESI) for $\mathrm{C}_{27} \mathrm{H}_{34} \mathrm{~N}_{3} \mathrm{O}_{3}[\mathrm{M}+\mathrm{H}]^{+} \mathrm{m} / z$ : calcd, 448.2600; found, 448.2591.

1-(2-Fluoroethyl)-4-(4-(4-methyl-5-(3,4,5-trimethoxyphenyl)pyridin-3-yl)phenyl)piperazine (14d). ${ }^{1} \mathrm{H}$ NMR (500 MHz, MeOD$\left.d_{4}\right) \delta 8.18(\mathrm{~s}, 2 \mathrm{H}), 7.19(\mathrm{~d}, J=8.6 \mathrm{~Hz}, 2 \mathrm{H}), 6.99(\mathrm{~d}, J=8.6 \mathrm{~Hz}, 2 \mathrm{H})$, $6.57(\mathrm{~s}, 2 \mathrm{H}), 4.58(\mathrm{t}, J=4.7 \mathrm{~Hz}, 1 \mathrm{H}), 4.49(\mathrm{t}, J=4.9 \mathrm{~Hz}, 1 \mathrm{H}), 3.77(\mathrm{~s}$, $6 \mathrm{H}), 3.72(\mathrm{~s}, 3 \mathrm{H}), 3.21-3.17(\mathrm{~m}, 4 \mathrm{H}), 2.75-2.69(\mathrm{~m}, 1 \mathrm{H}), 2.69-2.62$ (m, 5H), $2.13(\mathrm{~s}, 3 \mathrm{H})$. HRMS (ESI) for $\mathrm{C}_{27} \mathrm{H}_{33} \mathrm{FN}_{3} \mathrm{O}_{3}[\mathrm{M}+\mathrm{H}]^{+} \mathrm{m} / z$ : calcd, 466.2506; found, 466.2495 .

1-(4-(4-(4-Methyl-5-(3,4,5-trimethoxyphenyl)pyridin-3-yl)phenyl)piperazin-1-yl)ethan-1-one (14e). ${ }^{1} \mathrm{H}$ NMR $(500 \mathrm{MHz}$, DMSO- $\left.d_{6}\right) \delta 8.37(\mathrm{~s}, 1 \mathrm{H}), 8.34(\mathrm{~s}, 1 \mathrm{H}), 7.33(\mathrm{br} \mathrm{d}, J=8.3 \mathrm{~Hz}, 2 \mathrm{H})$, $7.07(\mathrm{br} \mathrm{d}, J=8.6 \mathrm{~Hz}, 2 \mathrm{H}), 6.73(\mathrm{~s}, 2 \mathrm{H}), 3.82(\mathrm{~s}, 6 \mathrm{H}), 3.72(\mathrm{~s}, 3 \mathrm{H}), 3.60$ (br s, 4H), 3.25 (br s, 2H), $3.18($ br s, $2 \mathrm{H}), 2.19(\mathrm{~s}, 3 \mathrm{H}), 2.06(\mathrm{~s}, 3 \mathrm{H})$. HRMS (ESI) for $\mathrm{C}_{27} \mathrm{H}_{32} \mathrm{~N}_{3} \mathrm{O}_{4}[\mathrm{M}+\mathrm{H}]^{+} \mathrm{m} / z$ : calcd, 462.2393; found, 462.2391.

$\mathrm{N}, \mathrm{N}$-Dimethyl-4-(4-(4-methyl-5-(3,4,5-trimethoxyphenyl)pyridin3-yl)phenyl)piperazine-1-carboxamide (14f). ${ }^{1} \mathrm{H}$ NMR $(500 \mathrm{MHz}$, DMSO- $\left.d_{6}\right) \delta 8.37(\mathrm{~s}, 1 \mathrm{H}), 8.34(\mathrm{~s}, 1 \mathrm{H}), 7.33(\mathrm{~d}, J=8.6 \mathrm{~Hz}, 2 \mathrm{H}), 7.08$ $(\mathrm{d}, J=8.7 \mathrm{~Hz}, 2 \mathrm{H}), 6.73(\mathrm{~s}, 2 \mathrm{H}), 3.82(\mathrm{~s}, 6 \mathrm{H}), 3.72(\mathrm{~s}, 3 \mathrm{H}), 3.28(\mathrm{br} \mathrm{d}, J$ $=6.1 \mathrm{~Hz}, 4 \mathrm{H}), 3.23(\mathrm{br} \mathrm{d}, J=5.7 \mathrm{~Hz}, 4 \mathrm{H}), 2.80(\mathrm{~s}, 6 \mathrm{H}), 2.19(\mathrm{~s}, 3 \mathrm{H})$. HRMS (ESI) for $\mathrm{C}_{28} \mathrm{H}_{35} \mathrm{~N}_{4} \mathrm{O}_{4}[\mathrm{M}+\mathrm{H}]^{+} \mathrm{m} / z$ : calcd, 491.2658; found, 491.2652.

1-(4-(4-Methyl-5-(3,4,5-trimethoxyphenyl)pyridin-3-yl)phenyl)-4(methylsulfonyl)piperazine (14g). ${ }^{1} \mathrm{H} \mathrm{NMR}\left(500 \mathrm{MHz}, \mathrm{MeOD}-d_{4}\right) \delta$ $8.32(\mathrm{~s}, 1 \mathrm{H}), 8.30(\mathrm{~s}, 1 \mathrm{H}), 7.34(\mathrm{~d}, J=8.7 \mathrm{~Hz}, 2 \mathrm{H}), 7.15(\mathrm{~d}, J=8.7 \mathrm{~Hz}$, $2 \mathrm{H}), 6.69(\mathrm{~s}, 2 \mathrm{H}), 3.89(\mathrm{~s}, 6 \mathrm{H}), 3.84(\mathrm{~s}, 3 \mathrm{H}), 3.44-3.37(\mathrm{~m}, 8 \mathrm{H}), 2.92$ $(\mathrm{s}, 3 \mathrm{H}), 2.44(\mathrm{~s}, 3 \mathrm{H})$. HRMS (ESI) for $\mathrm{C}_{26} \mathrm{H}_{32} \mathrm{~N}_{3} \mathrm{O}_{5} \mathrm{~S}[\mathrm{M}+\mathrm{H}]^{+} \mathrm{m} / z$ : calcd, 498.2063; found, 498.2049.

4-(4-(4-Methyl-5-(3,4,5-trimethoxyphenyl)pyridin-3-yl)phenyl)morpholine (14h). ${ }^{1} \mathrm{H}$ NMR (500 MHz, DMSO- $\left.d_{6}\right) \delta 8.35(\mathrm{~s}, 1 \mathrm{H})$, $8.33(\mathrm{~s}, 1 \mathrm{H}), 7.32(\mathrm{br} \mathrm{d}, J=8.1 \mathrm{~Hz}, 2 \mathrm{H}), 7.06(\mathrm{br} \mathrm{d}, J=8.2 \mathrm{~Hz}, 2 \mathrm{H})$, $6.73(\mathrm{~s}, 2 \mathrm{H}), 3.82(\mathrm{~s}, 6 \mathrm{H}), 3.76(\mathrm{br} \mathrm{d}, J=4.0 \mathrm{~Hz}, 4 \mathrm{H}), 3.72(\mathrm{~s}, 3 \mathrm{H}), 3.18$ (br d, $J=4.2 \mathrm{~Hz}, 4 \mathrm{H}), 2.19(\mathrm{~s}, 3 \mathrm{H})$. HRMS (ESI) for $\mathrm{C}_{25} \mathrm{H}_{29} \mathrm{~N}_{2} \mathrm{O}_{4}[\mathrm{M}+$ $\mathrm{H}]^{+} \mathrm{m} / z$ : calcd, 421.2127; found, 421.2123 .

4-(4-(4-Methyl-5-(3,4,5-trimethoxyphenyl)pyridin-3-yl)phenyl)thiomorpholine 1, 1-Dioxide (14i). ${ }^{1} \mathrm{H}$ NMR $\left(500 \mathrm{MHz}\right.$, DMSO-d $\left.d_{6}\right) \delta$ $8.37(\mathrm{~s}, 1 \mathrm{H}), 8.34(\mathrm{~s}, 1 \mathrm{H}), 7.35(\mathrm{br} \mathrm{d}, J=8.6 \mathrm{~Hz}, 2 \mathrm{H}), 7.15(\mathrm{br} \mathrm{d}, J=8.7$ $\mathrm{Hz}, 2 \mathrm{H}), 6.73(\mathrm{~s}, 2 \mathrm{H}), 3.85(\mathrm{br} \mathrm{s}, 4 \mathrm{H}), 3.82(\mathrm{~s}, 6 \mathrm{H}), 3.72(\mathrm{~s}, 3 \mathrm{H}), 3.16$ (br s, $4 \mathrm{H}), 2.20(\mathrm{~s}, 3 \mathrm{H})$. HRMS (ESI) for $\mathrm{C}_{25} \mathrm{H}_{29} \mathrm{~N}_{2} \mathrm{O}_{5} \mathrm{~S}[\mathrm{M}+\mathrm{H}]^{+} \mathrm{m} / z$ : calcd, 469.1797; found, 469.1793.

4-Methyl-3-(4-(piperidin-4-yl)phenyl)-5-(3,4,5trimethoxyphenyl)pyridine (14j). ${ }^{1} \mathrm{H}$ NMR (500 MHz, MeOD-d $\left.d_{4}\right) \delta$ $8.36(\mathrm{~s}, 1 \mathrm{H}), 8.30(\mathrm{~s}, 1 \mathrm{H}), 7.42(\mathrm{q}, J=8.3 \mathrm{~Hz}, 4 \mathrm{H}), 6.70(\mathrm{~s}, 2 \mathrm{H}), 3.89(\mathrm{~s}$, $6 \mathrm{H}), 3.84(\mathrm{~s}, 3 \mathrm{H}), 3.45(\mathrm{~d}, J=12.8 \mathrm{~Hz}, 2 \mathrm{H}), 3.08(\mathrm{td}, J=12.7,2.3 \mathrm{~Hz}$, $2 \mathrm{H}), 2.96$ (ddd, $J=12.1,8.8,3.5 \mathrm{~Hz}, 1 \mathrm{H}), 2.23(\mathrm{~s}, 3 \mathrm{H}), 2.10(\mathrm{~d}, J=13.8$ $\mathrm{Hz}, 2 \mathrm{H}$ ), 1.92 (qd, $J=13.5,3.8 \mathrm{~Hz}, 2 \mathrm{H}$ ). HRMS (ESI) for $\mathrm{C}_{26} \mathrm{H}_{31} \mathrm{~N}_{2} \mathrm{O}_{3}$ $[\mathrm{M}+\mathrm{H}]^{+} \mathrm{m} / z$ : calcd, 419.2335 ; found, 419.2330 .

4-Methyl-3-(4-(1-methylpiperidin-4-yl)phenyl)-5-(3,4,5trimethoxyphenyl)pyridine (14k) (M4K2117). ${ }^{1} \mathrm{H}$ NMR $(500 \mathrm{MHz}$, MeOD- $\left.d_{4}\right) \delta 8.35(\mathrm{~s}, 1 \mathrm{H}), 8.31(\mathrm{~s}, 1 \mathrm{H}), 7.42(\mathrm{~d}, J=8.2 \mathrm{~Hz}, 2 \mathrm{H}), 7.37$ $(\mathrm{d}, J=8.2 \mathrm{~Hz}, 2 \mathrm{H}), 6.70(\mathrm{~s}, 2 \mathrm{H}), 3.90(\mathrm{~s}, 6 \mathrm{H}), 3.85(\mathrm{~s}, 3 \mathrm{H}), 3.08(\mathrm{~d}, J=$ $11.7 \mathrm{~Hz}, 2 \mathrm{H}), 2.72-2.63(\mathrm{~m}, 1 \mathrm{H}), 2.40(\mathrm{~s}, 3 \mathrm{H}), 2.30-2.23(\mathrm{~m}, 2 \mathrm{H})$, 2.23 (br s, $3 \mathrm{H}$ ), 1.95-1.86 (m, 4H). HRMS (ESI) for $\mathrm{C}_{27} \mathrm{H}_{33} \mathrm{~N}_{2} \mathrm{O}_{3}[\mathrm{M}$ $+\mathrm{H}]^{+} \mathrm{m} / z$ : calcd, 433.2491; found, 433.2485 .

4-Methyl-3-(4-(1,2,3,6-tetrahydropyridin-4-yl)phenyl)-5-(3,4,5trimethoxyphenyl)pyridine (14l). ${ }^{1} \mathrm{H}$ NMR $\left(500 \mathrm{MHz}, \mathrm{MeOD}-d_{4}\right) \delta$ $8.23(\mathrm{~s}, 1 \mathrm{H}), 8.20(\mathrm{~s}, 1 \mathrm{H}), 7.47(\mathrm{~d}, J=8.3 \mathrm{~Hz}, 2 \mathrm{H}), 7.28(\mathrm{~d}, J=8.3 \mathrm{~Hz}$, $2 \mathrm{H}), 6.58(\mathrm{~s}, 2 \mathrm{H}), 6.20-6.13(\mathrm{~m}, 1 \mathrm{H}), 3.77(\mathrm{~s}, 6 \mathrm{H}), 3.72(\mathrm{~s}, 3 \mathrm{H}), 3.46$ $(\mathrm{dd}, J=5.6,2.6 \mathrm{~Hz}, 2 \mathrm{H}), 3.05(\mathrm{t}, J=5.8 \mathrm{~Hz}, 2 \mathrm{H}), 2.54-2.46(\mathrm{~m}, 2 \mathrm{H})$, $2.12(\mathrm{~s}, 3 \mathrm{H})$. HRMS (ESI) for $\mathrm{C}_{26} \mathrm{H}_{29} \mathrm{~N}_{2} \mathrm{O}_{3}[\mathrm{M}+\mathrm{H}]^{+} \mathrm{m} / z$ : calcd, 417.2178; found, 417.2172.

4-Methyl-3-(4-(1-methyl-1,2,3,6-tetrahydropyridin-4-yl)phenyl)5-(3,4,5-trimethoxyphenyl)pyridine (14m). ${ }^{1} \mathrm{H}$ NMR $(500 \mathrm{MHz}$, $\left.\mathrm{MeOD}-d_{4}\right) \delta 8.35(\mathrm{~s}, 1 \mathrm{H}), 8.33(\mathrm{~s}, 1 \mathrm{H}), 7.60(\mathrm{~d}, J=8.2 \mathrm{~Hz}, 2 \mathrm{H}), 7.41$ $(\mathrm{d}, J=8.2 \mathrm{~Hz}, 2 \mathrm{H}), 6.70(\mathrm{~s}, 2 \mathrm{H}), 6.26(\mathrm{~s}, 1 \mathrm{H}), 3.89(\mathrm{~s}, 6 \mathrm{H}), 3.84(\mathrm{~s}$, $3 \mathrm{H}), 3.28(\mathrm{~d}, J=2.0 \mathrm{~Hz}, 2 \mathrm{H}), 2.86(\mathrm{t}, J=5.7 \mathrm{~Hz}, 2 \mathrm{H}), 2.73(\mathrm{~s}, 2 \mathrm{H}), 2.50$ (s, 3H), $2.24(\mathrm{~s}, 3 \mathrm{H})$. HRMS (ESI) for $\mathrm{C}_{27} \mathrm{H}_{31} \mathrm{~N}_{2} \mathrm{O}_{3}[\mathrm{M}+\mathrm{H}]^{+} \mathrm{m} / z$ : calcd, 431.2335; found, 431.2328.

1-(4-(4-Methyl-5-(3,4,5-trimethoxyphenyl)pyridin-3-yl)phenyl)1,4-diazepane (14n). ${ }^{1} \mathrm{H}$ NMR (500 MHz, DMSO- $\left.d_{6}\right) \delta 8.33(\mathrm{~s}, 2 \mathrm{H})$, $7.24(\mathrm{~d}, J=8.7 \mathrm{~Hz}, 2 \mathrm{H}), 6.80(\mathrm{~d}, J=8.8 \mathrm{~Hz}, 2 \mathrm{H}), 6.73(\mathrm{~s}, 2 \mathrm{H}), 3.81(\mathrm{~s}$, $6 \mathrm{H}), 3.72(\mathrm{~s}, 3 \mathrm{H}), 3.57(\mathrm{t}, J=6.0 \mathrm{~Hz}, 2 \mathrm{H}), 3.54-3.49(\mathrm{~m}, 2 \mathrm{H}), 2.95-$ $2.87(\mathrm{~m}, 2 \mathrm{H}), 2.73-2.66(\mathrm{~m}, 2 \mathrm{H}), 2.21(\mathrm{~s}, 3 \mathrm{H}), 1.86-1.78(\mathrm{~m}, 2 \mathrm{H})$. HRMS (ESI) for $\mathrm{C}_{26} \mathrm{H}_{32} \mathrm{~N}_{3} \mathrm{O}_{3}[\mathrm{M}+\mathrm{H}]^{+} \mathrm{m} / z$ : calcd, 434.2444; found, 434.2433

1-Methyl-4-(4-(4-methyl-5-(3,4,5-trimethoxyphenyl)pyridin-3yl)benzyl)piperazine (140). ${ }^{1} \mathrm{H}$ NMR $\left(500 \mathrm{MHz}, \mathrm{MeOD}-d_{4}\right) \delta 8.35$ (s, $1 \mathrm{H}), 8.31(\mathrm{~s}, 1 \mathrm{H}), 7.50(\mathrm{~d}, J=7.9 \mathrm{~Hz}, 2 \mathrm{H}), 7.40(\mathrm{~d}, J=8.0 \mathrm{~Hz}, 2 \mathrm{H})$, $6.70(\mathrm{~s}, 2 \mathrm{H}), 3.89(\mathrm{~s}, 6 \mathrm{H}), 3.84(\mathrm{~s}, 3 \mathrm{H}), 3.65(\mathrm{~s}, 2 \mathrm{H}), 2.83-2.43(\mathrm{br} \mathrm{s}$, $8 \mathrm{H}), 2.36(\mathrm{~s}, 3 \mathrm{H}), 2.23(\mathrm{~s}, 3 \mathrm{H})$. HRMS (ESI) for $\mathrm{C}_{27} \mathrm{H}_{34} \mathrm{~N}_{3} \mathrm{O}_{3}[\mathrm{M}+$ $\mathrm{H}]^{+} \mathrm{m} / z$ : calcd, 448.2600; found, 448.2592 .

4-Methyl-3-(4-(piperidin-4-yloxy)phenyl)-5-(3,4,5trimethoxyphenyl)pyridine (14p). ${ }^{1} \mathrm{H}$ NMR $\left(500 \mathrm{MHz}, \mathrm{MeOD}-d_{4}\right) \delta$ $8.34(\mathrm{~s}, 1 \mathrm{H}), 8.31(\mathrm{~s}, 1 \mathrm{H}), 7.37(\mathrm{~d}, J=8.7 \mathrm{~Hz}, 2 \mathrm{H}), 7.13(\mathrm{~d}, J=8.7 \mathrm{~Hz}$, $2 \mathrm{H}), 6.70(\mathrm{~s}, 2 \mathrm{H}), 4.72-4.66(\mathrm{~m}, 1 \mathrm{H}), 3.90(\mathrm{~s}, 6 \mathrm{H}), 3.85(\mathrm{~s}, 3 \mathrm{H})$, $3.32-3.26(\mathrm{~m}, 2 \mathrm{H}), 3.04-2.98(\mathrm{~m}, 2 \mathrm{H}), 2.24(\mathrm{~s}, 3 \mathrm{H}), 2.19-2.12(\mathrm{~m}$, $2 \mathrm{H}), 1.95-1.87(\mathrm{~m}, 2 \mathrm{H})$. HRMS (ESI) for $\mathrm{C}_{26} \mathrm{H}_{31} \mathrm{~N}_{2} \mathrm{O}_{4}[\mathrm{M}+\mathrm{H}]^{+} \mathrm{m} /$ $z$ : calcd, 435.2284; found, 435.2273 .

4-Methyl-3-(4-((1-methylpiperidin-4-yl)oxy)phenyl)-5-(3,4,5trimethoxyphenyl)pyridine (14q). ${ }^{1} \mathrm{H}$ NMR $\left(500 \mathrm{MHz}, \mathrm{MeOD}-d_{4}\right) \delta$ $8.21(\mathrm{~s}, 1 \mathrm{H}), 8.19(\mathrm{~s}, 1 \mathrm{H}), 7.23(\mathrm{~d}, J=8.7 \mathrm{~Hz}, 2 \mathrm{H}), 6.97(\mathrm{~d}, J=8.7 \mathrm{~Hz}$, $2 \mathrm{H}), 6.58(\mathrm{~s}, 2 \mathrm{H}), 4.46-4.37$ (br m, $1 \mathrm{H}), 3.77(\mathrm{~s}, 6 \mathrm{H}), 3.72(\mathrm{~s}, 3 \mathrm{H})$, 2.74-2.62 (br m, 2H), 2.41-2.30 (br m, $2 \mathrm{H}), 2.25$ (s, 3H), 2.12 (s, $3 \mathrm{H}), 2.02-1.92(\mathrm{br} \mathrm{m}, 2 \mathrm{H}), 1.81-1.72(\mathrm{br} \mathrm{m}, 2 \mathrm{H})$. HRMS (ESI) for $\mathrm{C}_{27} \mathrm{H}_{33} \mathrm{~N}_{2} \mathrm{O}_{4}[\mathrm{M}+\mathrm{H}]^{+} \mathrm{m} / z$ : calcd, 449.2440; found, 449.2429.

Kinase Assay. The biochemical potencies of all compounds were measured by Reaction Biology Corporation (Malvern, Pennsylvania). Compounds were tested against ALK1/ACVRL1, ALK2/ACVR1, ALK3/BMPR1 $\alpha$, ALK4/ACVR1 $\beta$, ALK5/TGF $\beta$-R1, and ALK6/ BMPR $1 \beta$ in a 10 -dose $\mathrm{IC}_{50}$ mode with a twofold serial dilution starting at 1 or $5 \mu \mathrm{M}$. Reactions were conducted at an ATP concentration of 10 $\mu \mathrm{M}$ and Casein concentration of $1 \mathrm{mg} / \mathrm{mL}$. LDN-193189 was tested as a control in a 10-dose $\mathrm{IC}_{50}$ mode with a threefold serial dilution starting at $10 \mu \mathrm{M}$. Reductions in enzymatic activity were determined relative to dimethyl sulfoxide (DMSO) controls.

Cell Culture and Transfection. HEK-293 cells were maintained in Dulbecco's modified Eagle's medium (DMEM, Gibco) supplemented with $10 \%$ fetal bovine serum (FBS) (Thermo Fisher) and penicillin/ streptomycin (Thermo Fisher). HEK-293 cells were transfected with the protein expression or reporter constructs using FuGENE HD (Promega) according to the manufacturer's instructions. Briefly, DNA was diluted into phenol red-free Opti-MEM (Gibco) at a concentration of $10 \mu \mathrm{g} / \mathrm{mL}$. Without coming in contact with the sides of the container, $3 \mu \mathrm{L}$ of FuGENE HD was added for each microgram of DNA used. After thorough mixing by inversion, FuGENE HD/DNA complexes were allowed to form by incubation at room temperature for $20 \mathrm{~min}$. The transfection mixture ( 1 part) was added to 20 parts of the HEK293 cell suspension with a density of 200000 cells per $\mathrm{mL}$ (volume/ volume). HEK-293 cells were incubated in a humidified, $37{ }^{\circ} \mathrm{C}$ 
incubator with $5 \% \mathrm{CO}_{2}$ for $24 \mathrm{~h}$ before they were used in the NanoBRET target engagement assay or dual luciferase reporter assay.

NanoBRET Target Engagement Assay. ALK2-C-terminal nanoluciferase fusion with a GSSG linker was encoded by the pFC32K vector (Promega). ALK2-nanoluciferase fusion construct (1 part) was mixed with 9 parts of Transfection Carrier DNA (mass/mass) (Promega). Transfected cells were trypsinized and resuspended in Opti-MEM at a density of 200000 cells per mL. Cells $(17 \mu \mathrm{L})$ were dispensed into each well of a 384-well flat-bottom polypropylene plate (Greiner). Working solution $(20 \times)$ of the target engagement tracer PBI-6908 (Promega) was prepared by diluting DMSO stock in tracer dilution buffer (12.5 mM HEPES pH 7.5, 31.25\% PEG-400). Stocks $(1000 \times)$ of test compounds in DMSO (Cell Signaling Technology) were diluted further in Opti-MEM for 10× working solutions. After the addition of $1 \mu \mathrm{L}$ of $20 \times$ target engagement tracer and $2 \mu \mathrm{L}$ of $10 \times$ working solutions, contents of the wells were thoroughly mixed by agitating the plate at $500 \mathrm{rpm}$ for $1 \mathrm{~min}$. Cells were incubated in a humidified, $37{ }^{\circ} \mathrm{C}$ incubator with $5 \% \mathrm{CO}_{2}$ for $2 \mathrm{~h}$ prior to bioluminescence resonance energy transfer (BRET) measurement. For BRET measurement, the NanoBRET NanoGlo Substrate and the Extracellular NanoLuc Inhibitor (Promega) were diluted 166× and $500 \times$, respectively, in Opti-MEM to produce $3 \times$ working stock. A PHERAstar FSX microplate reader (BMG Labtech) with the LUM 610-LP 460-80 optical module was used to measure the intensity of dual emission. A measurement interval of $1 \mathrm{~s}$ and gain settings of 3600 and 1879 for 610 and $460 \mathrm{~nm}$, respectively, were used. Milli-BRET units $(\mathrm{mBU})$ were calculated by dividing the signal measured at $610 \mathrm{~nm}$ with the signal measured at $460 \mathrm{~nm}$ and multiplying by 1000 . The apparent $\mathrm{EC}_{50}$ values of test compounds were estimated using the [Inhibitor] versus response (three-parameter) nonlinear regression curve fitting function of GraphPad Prism 7.

Dual Luciferase Reporter Assay. CAGA-Luc and Renillaluciferase constructs (a gift from Dr. Petra Knaus, Free University of Berlin) were used as reporters for ALK5 signaling and loading control, respectively. The CAGA-Luc construct (4 parts) was mixed with 1 part of Renilla-luciferase construct (mass/mass). Ten thousand transfected cells were seeded into each well of a 96 -well plate (Corning). Some $24 \mathrm{~h}$ after transfection, the cells were incubated with $10 \mathrm{ng} / \mathrm{mL}$ TGF $\beta 1$ (Peprotech, 100-21-10) and test compounds simultaneously at the concentrations indicated in a humidified, $37{ }^{\circ} \mathrm{C}$ incubator with $5 \%$ $\mathrm{CO}_{2}$. Another $24 \mathrm{~h}$ later, the cells were harvested, lysed, and processed for the measurement of luciferase activity using the Dual-Luciferase Reporter Assay System (Promega) according to the manufacturer's instructions. Briefly, the culture medium was aspirated completely, and cells were lysed in $50 \mu \mathrm{L}$ of $1 \times$ PLB with $300 \mathrm{rpm}$ agitation for $30 \mathrm{~min}$. The cell lysate $(10 \mu \mathrm{L})$ was dispensed into each well of a 384-well flatbottom polypropylene plate (Greiner). The luminescent signal of firefly- and Renilla-luciferase activity was measured sequentially using a PHERAstar FS microplate reader (BMG Labtech) after the addition of $25 \mu \mathrm{L}$ of LARII and Stop \& Glo, respectively. A measurement interval of $2 \mathrm{~s}$ and gain setting of 3600 were used. The firefly-luciferase signal was normalized to the cell number by division with the Renilla-luciferase signal. The relative luciferase unit (RLU) was obtained by further division with the signal from cells without TGF $\beta$ stimulation. The apparent $\mathrm{EC}_{50}$ values of test compounds were estimated using the [Inhibitor] versus response (three-parameter) nonlinear regression curve fitting function of GraphPad Prism 7.

Caco-2 Permeability Assay. Caco-2 cells (C2BBe1) were purchased from American Type Culture Collection (ATCC). Caco-2 cell cultures were routinely maintained in T-75 tissue culture flasks in DMEM containing $20 \%$ FBS, $0.1 \mathrm{mg} / \mathrm{mL}$ normocin, and $0.05 \mathrm{mg} / \mathrm{mL}$ gentamicin. These cells were seeded at a density of 40000 cells per well on the 24-well poly(ethylene terephthalate) (PET) membrane (1.0 $\mu \mathrm{m}$ pore size, $0.3 \mathrm{~cm}^{2}$ surface area) insert plates. Cell monolayers were grown for 21 or 22 days at $37{ }^{\circ} \mathrm{C}$ with $5 \% \mathrm{CO}_{2}$ in a humidified incubator. The cell culture medium was replaced twice weekly during the cell growth period. Prior to beginning the permeability assay, cell monolayers were rinsed with Hank's balanced salt solution (HBSS) twice to remove the residual cell culture medium. The assay buffer comprised HBSS containing $10 \mathrm{mM}$ HEPES and $15 \mathrm{mM}$ glucose at $\mathrm{pH}$
7.4. The dosing buffer contained $5 \mu \mathrm{M}$ metoprolol (positive control), 5 $\mu \mathrm{M}$ atenolol (negative control), and $100 \mu \mathrm{M}$ Lucifer yellow in the assay buffer. The receiving buffer contained $1 \%$ bovine serum albumin (BSA) in the assay buffer. The concentration of the test compound was $5 \mu \mathrm{M}$ in the dosing buffer (final DMSO concentration was 0.1\%). Digoxin at $10 \mu \mathrm{M}$ was utilized as a P-gp substrate control. For the apical to basolateral (A to B) permeability experiment, $0.25 \mathrm{~mL}$ of the dosing buffer was added to the apical chambers, and $1.0 \mathrm{~mL}$ of the receiving buffer was added to the basolateral chambers of the assay plate. For the basolateral to apical (B to A) permeability experiment, $0.25 \mathrm{~mL}$ of the receiving buffer was added to the apical chambers, and $1.0 \mathrm{~mL}$ of dosing buffer was added to the basolateral chambers of the assay plates. The assay plates were then incubated at $37^{\circ} \mathrm{C}$ for $2 \mathrm{~h}$ on an orbital shaker at $65 \mathrm{rpm}$. Sample solutions were taken from the donor chambers $(10 \mu \mathrm{L})$ and receiver chambers $(100 \mu \mathrm{L})$ after the incubation period. For each sample, there were two technical replicates. The sample solutions from donor chambers were diluted $10 \times$ with the receiving buffer. To extract test compounds and precipitate BSA from sample solutions, three volumes of acetonitrile (containing $0.5 \%$ formic acid and an internal standard) were added, and the plate was vigorously mixed. Sample solutions were then centrifuged at $4000 \mathrm{rpm}$ for $10 \mathrm{~min}$ to remove debris and precipitated BSA. Approximately $150 \mu \mathrm{L}$ of the supernatant was subsequently transferred to a new 96-well microplate for LC/MS analysis. Narrow-window mass extraction LC/MS analysis was performed for all samples using a Waters Acquity UPLC system with a Waters Xevo quadrupole-time-of-flight (Q-TOF) mass spectrometer to determine relative peak areas of the parent compounds. Chromatographic separations were performed on a Waters Acquity UPLC HSS T3 column $(2.1 \mathrm{~mm} \times 100 \mathrm{~mm}, 100 \AA, 1.8 \mu \mathrm{m}$, part no. 186003539$)$ at $30{ }^{\circ} \mathrm{C}$. Mobile phases A and B were $0.1 \%$ formic acid in water and $0.1 \%$ formic acid in acetonitrile, respectively. The sample temperature was kept at $10{ }^{\circ} \mathrm{C}$. The typical injection volume was $0.3 \mu \mathrm{L}$. Chromatographic gradients used are shown in the table below.

$\begin{array}{ccrr}\text { Time }(\mathrm{min}) & \text { Flow Rate }(\mu \mathrm{L} / \mathrm{min}) & \% \mathrm{~A} & \% \mathrm{~B} \\ 0.0 & 0.400 & 100 & 0 \\ 0.5 & 0.400 & 100 & 0 \\ 4.5 & 0.400 & 5 & 95 \\ 5.0 & 0.400 & 5 & 95 \\ 5.5 & 0.400 & 100 & 0 \\ 6.5 & 0.400 & 100 & 0\end{array}$

Data acquisition was performed in the electrospray (ES) positive ion mode in the mass range of $100-1000 \mathrm{~m} / z$. The following source parameters were used: capillary voltage, $0.8 \mathrm{kV}$; cone voltage, $25 \mathrm{~V}$; source temperature, $150{ }^{\circ} \mathrm{C}$; desolvation temperature, $500{ }^{\circ} \mathrm{C}$; cone gas flow, $150 \mathrm{~L} / \mathrm{h}$; desolvation gas flow, $600 \mathrm{~L} / \mathrm{h}$. Accurate masses were measured in the lock-spray automated exact mass measurement mode. The fragment ions of leucine-enkephalin were used as reference substances (lock-mass) in the acquisition mode. The following lockspray configuration was used: frequency, $10 \mathrm{~s}$; cone voltage, $25 \mathrm{~V}$; collision energy, $22 \mathrm{~V}$. Data processing was performed using MassLynx 4.1 software (Waters). The co-dosed positive and negative controls were also measured for each well to monitor integrity of cell monolayers and well-to-well variability. The apparent permeability coefficient $\left(P_{\text {app }}\right)$ and post-assay recovery are calculated using the following equations

$$
\begin{aligned}
P_{\text {app }}=V_{\mathrm{r}} \times(\mathrm{d} C / \mathrm{d} t) \times 1 /\left(A \times C_{0}\right) & \\
\text { percent recovery }= & 100 \times\left[\left(V_{\mathrm{r}} \times C_{\mathrm{r}}{ }^{\text {final }}\right)+\left(V_{\mathrm{d}} \times C_{\mathrm{d}}{ }^{\text {final }}\right)\right] \\
& /\left(V_{\mathrm{d}} \times C_{0}\right)
\end{aligned}
$$

where $\mathrm{dC} / \mathrm{d} t$ is the slope of cumulative concentration in the receiver compartment versus time, $V_{\mathrm{r}}$ is the volume of the receiver compartment, $V_{\mathrm{d}}$ is the volume of the donor compartment, $A$ is the membrane surface area, $C_{0}$ is the initial compound concentration in the donor chamber, $C_{\mathrm{r}}^{\text {final }}$ is the cumulative receiver concentration at the end of the incubation period, and $C_{\mathrm{d}}^{\text {final }}$ is the concentration of the donor at the end of the incubation period. The efflux ratio (ER) is defined as $P_{\text {app }}$ (Bto-A) $/ P_{\text {app }}$ (A-to-B). 
Liver Microsomal Metabolic Stability Assay. For this assay, stock solutions of test compounds in DMSO $(1 \mathrm{mM})$ were initially diluted to a concentration of $40.0 \mu \mathrm{M}$ using $0.1 \mathrm{M}$ potassium phosphate buffer ( $\mathrm{pH}$ 7.4). Test compounds were then added to reaction wells at a final concentration of $1 \mu \mathrm{M}$, which was assumed to be well below $K_{\mathrm{m}}$ values to ensure linear reaction conditions (i.e., avoid saturation). The final DMSO concentration was kept constant at $0.1 \%$. Each compound was tested in duplicate for both time points $(0$ and $60 \mathrm{~min}) . \mathrm{CD}-1$ mouse (male) or pooled human liver microsomes (Corning Gentest) were added to the reaction wells at a final concentration of $0.5 \mathrm{mg} / \mathrm{mL}$ (protein). The final volume for each reaction was $100 \mu \mathrm{L}$, which included the NADPH-regeneration solution (NRS) mix (Corning Gentest). This NRS mix comprised glucose 6-phosphate dehydrogenase, $\mathrm{NADP}^{+}, \mathrm{MgCl}_{2}$, and glucose 6-phosphate. Reactions were carried out at $37^{\circ} \mathrm{C}$ in an orbital shaker at $175 \mathrm{rpm}$. Upon completion of the 60 min time point, reactions were terminated by the addition of $2 \mathrm{~V}(200$ $\mu \mathrm{L}$ ) of ice-cold acetonitrile containing $0.5 \%$ formic acid and an internal standard. Samples were then centrifuged at $4000 \mathrm{rpm}$ for $10 \mathrm{~min}$ to remove debris and precipitated proteins. Approximately $150 \mu \mathrm{L}$ of supernatant was subsequently transferred to a new 96-well microplate for LC/MS analysis. Narrow-window mass extraction LC/MS analysis was performed for all samples using a Waters Acquity UPLC system with a Waters Xevo quadrupole-time-of-flight (Q-TOF) mass spectrometer to determine relative peak areas of the parent compounds. Chromatographic separations were performed on a Waters Acquity UPLC HSS T3 column $(2.1 \mathrm{~mm} \times 100 \mathrm{~mm}, 100 \AA, 1.8 \mu \mathrm{m}$, part no. 186003539 ) at $30^{\circ} \mathrm{C}$. Mobile phased $\mathrm{A}$ and $\mathrm{B}$ were $0.1 \%$ formic acid in water and $0.1 \%$ formic acid in acetonitrile, respectively. The sample temperature was kept at $10^{\circ} \mathrm{C}$. The typical injection volume was $0.3 \mu \mathrm{L}$. Chromatographic gradients used are shown in the table below.

$\begin{array}{ccrc}\text { Time }(\mathrm{min}) & \text { Flow Rate }(\mu \mathrm{L} / \mathrm{min}) & \% \mathrm{~A} & \% \mathrm{~B} \\ 0.0 & 0.450 & 100 & 0 \\ 2.5 & 0.450 & 5 & 95 \\ 3.0 & 0.450 & 5 & 95 \\ 3.5 & 0.450 & 100 & 0 \\ 4.5 & 0.450 & 100 & 0\end{array}$

Data acquisition was performed in the electrospray (ES) positive ion mode in the mass range of $100-1000 \mathrm{~m} / z$. The following source parameters were used: capillary voltage, $0.8 \mathrm{kV}$; cone voltage, $25 \mathrm{~V}$; source temperature, $150^{\circ} \mathrm{C}$; desolvation temperature, $500{ }^{\circ} \mathrm{C}$; cone gas flow, $150 \mathrm{~L} / \mathrm{h}$; desolvation gas flow, $600 \mathrm{~L} / \mathrm{h}$. Accurate masses were measured in the lock-spray automated exact mass measurement mode. The fragment ions of leucine-enkephalin were used as reference substances (lock-mass) in the acquisition mode. The following lockspray configuration was used: frequency, $10 \mathrm{~s}$; cone voltage, $25 \mathrm{~V}$; collision energy, $22 \mathrm{~V}$. Data processing was performed using MassLynx 4.1 software (Waters). The percentage remaining values were calculated using the following equation:

percent remaining $=\left(A / A_{0}\right) \times 100$

where $A$ is area response after incubation and $A_{0}$ is area response at the initial time point.

Plasma Protein Binding Assay. A 48-well format rapid equilibrium dialysis (RED) device from Thermo Fisher Scientific was used for the plasma protein binding assay. Each RED device insert contained a buffer and a plasma compartment separated by a semipermeable membrane with a molecular weight cutoff of approximately $8 \mathrm{kDa}$. Stock solutions of test compounds in DMSO $(1 \mathrm{mM})$ were spiked into heparinized pooled human plasma from Innovative Research (Novi, Michigan) at the final compound concentration of $5 \mu \mathrm{M}$ (final DMSO concentration was $0.5 \%$ ). The prepared plasma sample $(300 \mu \mathrm{L})$ was added to a plasma chamber, and $500 \mu \mathrm{L}$ of Dulbecco's phosphate-buffered saline (DPBS) was added to a buffer chamber. The RED plate was incubated in an orbital shaker at 37 ${ }^{\circ} \mathrm{C}$ and $200 \mathrm{rpm}$ for $4 \mathrm{~h}$. After the incubation, $50 \mu \mathrm{L}$ aliquots of postdialysis samples from the buffer and the plasma chambers were transferred to a 96-well deep well plate. Samples were matrix-matched for the analysis by the addition of $50 \mu \mathrm{L}$ of plasma to the buffer samples and $50 \mu \mathrm{L}$ of buffer to the plasma samples. Ice-cold acetonitrile (300 $\mu \mathrm{L}$ ) containing $0.5 \%$ formic acid and an internal standard was added to each well to precipitate plasma proteins. The deep well plate was tightly sealed with a plastic mat, mixed vigorously for $5 \mathrm{~min}$, and placed on ice for $30 \mathrm{~min}$. After the extraction step, the deep well plate was centrifuged for $10 \mathrm{~min}$ at $4000 \mathrm{rpm}$. Approximately $150 \mu \mathrm{L}$ of supernatant was subsequently transferred to a new 96-well microplate for LC/MS analysis. Narrow-window mass extraction LC/MS analysis was performed for all samples using a Waters Acquity UPLC system with a Waters Xevo quadrupole-time-of-flight (Q-TOF) mass spectrometer to determine relative peak areas of the parent compounds. Chromatographic separations were performed on a Waters Acquity UPLC HSS T3 column $(2.1 \mathrm{~mm} \times 100 \mathrm{~mm}, 100 \AA, 1.8 \mu \mathrm{m}$, part no. 186003539$)$ at $30^{\circ} \mathrm{C}$. Mobile phases A and B were $0.1 \%$ formic acid in water and $0.1 \%$ formic acid in acetonitrile, respectively. The sample temperature was kept at $10{ }^{\circ} \mathrm{C}$. The typical injection volume was $0.3 \mu \mathrm{L}$. Chromatographic gradients used are shown in the table below.

$\begin{array}{ccrr}\text { Time }(\min ) & \text { Flow Rate }(\mu \mathrm{L} / \mathrm{min}) & \% \mathrm{~A} & \% \mathrm{~B} \\ 0.0 & 0.400 & 100 & 0 \\ 4.5 & 0.400 & 5 & 95 \\ 5.0 & 0.400 & 5 & 95 \\ 5.5 & 0.400 & 100 & 0 \\ 6.5 & 0.400 & 100 & 0\end{array}$

Data acquisition was performed in the electrospray (ES) positive ion mode in the mass range of $100-1000 \mathrm{~m} / z$. The following source parameters were used: capillary voltage, $0.8 \mathrm{kV}$; cone voltage, $25 \mathrm{~V}$; source temperature, $150{ }^{\circ} \mathrm{C}$; desolvation temperature, $500{ }^{\circ} \mathrm{C}$; cone gas flow, $150 \mathrm{~L} / \mathrm{h}$; desolvation gas flow, $600 \mathrm{~L} / \mathrm{h}$. Accurate masses were measured in the lock-spray automated exact mass measurement mode. The fragment ions of leucine-enkephalin were used as reference substances (lock-mass) in the acquisition mode. The following lockspray configuration was used: frequency, $10 \mathrm{~s}$; cone voltage, $25 \mathrm{~V}$; collision energy, $22 \mathrm{~V}$. Data processing was performed using MassLynx 4.1 software (Waters). Each determination was performed in triplicate. The percentage of the bound test compound was calculated using the following equation:

$$
\text { percent bound }=100-\left[\left(A_{\text {buffer }} / A_{\text {plasma }}\right) \times 100\right]
$$

where $A_{\text {buffer }}$ is area response of the buffer chamber and $A_{\text {plasma }}$ is area response of the plasma chamber.

hERG Potassium Channel Inhibition Assay. hERG IC I0 $_{50}$ values were generated by Charles River Laboratories (Cleveland, Ohio). Compounds were tested against cloned hERG potassium channels expressed in HEK-293 cells. Chemicals used in solution preparation were purchased from Sigma-Aldrich (St. Louis, MO) unless otherwise noted and were of ACS reagent-grade purity or higher. Stock solutions of test articles and the positive control were prepared in dimethyl sulfoxide (DMSO) and stored frozen. Reference compound concentrations were prepared fresh daily by diluting stock solutions into a Charles River proprietary HEPES-buffered physiological saline (HBPS) solution, which was prepared weekly and refrigerated until use. Because previous results have shown that $\leq 0.3 \%$ DMSO did not affect channel currents, all test and control solutions contained 0.3\% DMSO. Each test article formulation was sonicated (model 2510/5510, Branson Ultrasonics, Danbury, CT) at ambient room temperature for $20 \mathrm{~min}$ to facilitate dissolution. Cells were cultured in DMEM/nutrient mixture F-12 (D-MEM/F-12) supplemented with $10 \%$ FBS, 100 U/mL penicillin G sodium, $100 \mu \mathrm{g} / \mathrm{mL}$ streptomycin sulfate, and $500 \mu \mathrm{g} / \mathrm{mL}$ G418. Before testing, cells in culture dishes were washed twice with HBSS and detached with accutase. Immediately before use in the IonWorks Barracuda system, the cells were washed twice in HB-PS to remove the accutase and resuspended in $5 \mathrm{~mL}$ of HB-PS. The test article effects were evaluated using IonWorks Barracuda systems (Molecular Devices Corporation, Union City, CA). HEPES-buffered intracellular solution (Charles River proprietary) for whole-cell recordings was loaded into the intracellular compartment of the Population Patch Clamp (PPC) planar electrode. Extracellular buffer (HB-PS) was loaded into PPC planar electrode plate wells $(11 \mu \mathrm{L}$ per well). The cell suspension was pipetted into the wells of the PPC planar 
electrode $(9 \mu \mathrm{L}$ per well). After establishment of a whole-cell configuration (the perforated patch), membrane currents were recorded using a patch clamp amplifier in the IonWorks Barracuda system. The current recordings were performed one time before test article application to the cells (baseline) and one time after application of the test article. Test article concentrations were applied to naive cells ( $n=4$, where $n=$ replicates per concentration). Each application consisted of addition of $20 \mu \mathrm{L}$ of $2 \times$ concentrated test article solution to the total $40 \mu \mathrm{L}$ of the final volume of the extracellular well of the PPC plate. The duration of exposure to each compound concentration was 5 min. The hERG current was measured using a pulse pattern with fixed amplitudes (conditioning prepulse: $-80 \mathrm{mV}$ for $25 \mathrm{~ms}$; test pulse: +40 $\mathrm{mV}$ for $80 \mathrm{~ms}$ ) from a holding potential of $0 \mathrm{mV}$ ("zero holding" procedure). The hERG current was measured as a difference between the peak current at $1 \mathrm{~ms}$ after the test step to $+40 \mathrm{mV}$ and the steadystate current at the end of the step to $+40 \mathrm{mV}$.

CYP Inhibition Assay. CYP IC $_{50}$ values were generated by Pharmaron (Beijing, China). Multiple concentrations $(1 \mu \mathrm{L})$ of the test compound or positive control compound (CYP1A2, furafylline; CYP2B6, ketoconazole; CYP2C8, quercetin; CYP2C9, sulfaphenazole; CYP2C19, N-3-benzylnirvanol; CYP2D6, quinidine; and CYP3A4, ketoconazole) were transferred to the "compound plate". The concentrations of test compounds and positive control compounds were $0,0.2,1,2,10,50,200,2000$, and $10000 \mu \mathrm{M}$. The master solution was prepared with $\mathrm{MgCl}_{2}$ solution (20 $\mu \mathrm{L}$ of $50 \mathrm{mM}$ solution), phosphate buffer $(100 \mu \mathrm{L}$ of $200 \mathrm{mM}$ solution), ultrapure water (56 $\mu \mathrm{L}$ ), human liver microsomes [ $2 \mu \mathrm{L}$ of $20 \mathrm{mg} / \mathrm{mL}$ stock concentration (Corning 1328 UltraPool HLM 150, Mixed Gender, cat. no. 452117)], and $1 \mu \mathrm{L}$ of substrate [CYP1A2, phenacetin ( $8 \mathrm{mM}$ stock concentration); CYP2B6, bupropion (10 mM stock concentration); CYP2C8, paclitaxel (1 mM stock concentration); CYP2C9, tolbutamide (40 mM stock concentration); CYP2C19, mephenytoin (10 mM stock concentration); CYP2D6, dextromethorphan (2 mM stock concentration); and CYP3A4, midazolam ( $1 \mathrm{mM}$ stock concentration), and testosterone (10 mM stock concentration)]. The master solution was prewarmed in a water bath at $37{ }^{\circ} \mathrm{C}$ for $5 \mathrm{~min}$. The incubated master solution $(179 \mu \mathrm{L})$ was transferred to the compound plate. In the mixed system, the final concentrations of the test compounds and positive control compounds were $0,0.001,0.005,0.01,0.05,0.25,1,10$, and $50 \mu \mathrm{M}$. All experiments were performed in duplicate. The reaction was started with the addition of $20 \mu \mathrm{L}$ of $10 \mathrm{mM}$ NADPH solution at the final concentration of $1 \mathrm{mM}$. The reaction was stopped by the addition of $1.5 \mathrm{~V}$ of methanol with IS (100 nM alprazolam, $200 \mathrm{nM}$ imipramine, $200 \mathrm{nM}$ labetalol, and $2 \mu \mathrm{M}$ ketoprofen) to the "incubation plate" at the designated time points (20 min for CYP1A2, 2B6, 2C9, 2C19, and 2D6, 5 min for midazolam-mediated 3A4, and $10 \mathrm{~min}$ for testosterone-mediated 3A4). The incubation plate was centrifuged at $3220 \mathrm{~g}$ for $40 \mathrm{~min}$ to precipitate the protein. An aliquot of $100 \mu \mathrm{L}$ of the supernatant was diluted using $100 \mu \mathrm{L}$ ultrapure water, and the mixture was used for LC/MS/MS analysis. The formation of metabolites was analyzed using LC/MS/MS. A decrease in the formation of the metabolites in the peak area to vehicle control was used to calculate the $\mathrm{IC}_{50}$ value (test compound concentration that produces $50 \%$ inhibition) using Excel Xlfit.

In Vivo Pharmacokinetic Studies. The pharmacokinetic profiles of $6 \mathrm{a}, 11 \mathrm{~b}, 14 \mathrm{~g}, 14 \mathrm{k}-\mathrm{l}$, and $14 \mathrm{p}$ were assessed by Pharmaron (Louisville, Kentucky), and all animal studies were performed in accordance with institutional guidelines as defined by the Institutional Animal Care and Use Committee. Test compounds were dissolved first in DMSO and then mixed with $47.5 \%$ PEG-400 and $47.5 \%$ deionized water with $10 \%$ Tween 80 . The solutions were thoroughly vortexed after each step and stored at room temperature. Solutions were freshly prepared on the day of dosing. Female CB17 SCID mice $(n=3)(6-8$ weeks old, 17-20 g weight) were orally administered a $10 \mathrm{mg} / \mathrm{kg}$ dose $(10 \mathrm{~mL} / \mathrm{kg}$ dose volume, $1 \mathrm{mg} / \mathrm{mL}$ concentration) of the test compound. Blood samples were taken via the dorsal metatarsal vein at $0.25,0.5,1,2,4,8$, and $24 \mathrm{~h}$ postdosage. Blood samples were transferred into plastic microcentrifuge tubes containing the anticoagulant Heparin- $\mathrm{Na}$ and centrifuged at $4000 \mathrm{~g}$ for $5 \mathrm{~min}$ at $4{ }^{\circ} \mathrm{C}$ to obtain plasma. The samples were stored in a freezer at $-75 \pm 15{ }^{\circ} \mathrm{C}$ prior to analysis.

To determine brain concentrations, female CB17 SCID mice $(n=3)$ (6-8 weeks old, $17-20 \mathrm{~g}$ weight) were orally administered a $100 \mathrm{mg} /$ $\mathrm{kg}$ dose $(10 \mathrm{~mL} / \mathrm{kg}$ dose volume, $10 \mathrm{mg} / \mathrm{mL}$ concentration $)$ of the test compound. At $4 \mathrm{~h}$ postdose, the animals were terminally anesthetized by an increasing concentration of $\mathrm{CO}_{2}$. Their chest cavities were opened to expose the heart, and an incision at the right auricle using surgical scissors was done. A syringe full of gentle saline was pushed into the heart slowly via the left ventricle (saline volume $\sim 10 \mathrm{~mL}$ ). The animal was placed head down at a $45^{\circ}$ angle to facilitate blood removal. Brain samples were collected and kept frozen at $-75 \pm 15^{\circ} \mathrm{C}$. All brain samples were weighed and homogenized with phosphate-buffered saline by a brain weight $(\mathrm{g})$-to-buffer volume $(\mathrm{mL})$ ratio of $1: 3$ before analysis. The actual concentrations were the detected value multiplied using the dilution factor.

Concentrations of the test compound in the plasma samples were analyzed using an LC/MS/MS method. WinNonlin (Phoenix, version 8.0) or other similar software was used for pharmacokinetic calculations. The following pharmacokinetic parameters were calculated, whenever possible, from the plasma concentration versus time data following $\mathrm{PO}$ administration: $t_{1 / 2}, C_{\max }, T_{\max }, \mathrm{AUC}_{\text {last }}, \mathrm{AUC}_{\text {inf }}$ and F.

Cocrystallization of ALK2 with M4K2009. Protein Expression and Purification. Constructs were prepared by ligation-independent cloning. The kinase domain of ALK2 (residues 201-499; Uniprot ID, Q04771) was cloned into pFB-LIC-Bse for the baculoviral expression. The construct was verified by sequencing. ALK2 was expressed in Sf9 insect cells grown at $27{ }^{\circ} \mathrm{C}$. Some $72 \mathrm{~h}$ postinfection, cells were harvested and lysed using ultrasonication. ALK2 was initially purified by nickel affinity chromatography before subsequent purification by size exclusion chromatography (Superdex 200 16/600). The eluted protein was stored in $50 \mathrm{mM}$ HEPES, pH 7.5, $300 \mathrm{mM} \mathrm{NaCl}, 10 \mathrm{mM}$ DTT. The hexahistidine tag of ALK2 was cleaved using tobacco etch virus protease after initial nickel purification.

Crystallization. Crystallization was achieved at $4{ }^{\circ} \mathrm{C}$ using the sitting-drop vapor diffusion method. ALK2 was preincubated with 1 $\mathrm{mM} \mathrm{M} 4 \mathrm{~K} 2009$ at a protein concentration of $11 \mathrm{mg} / \mathrm{mL}$ and crystallized using a precipitant containing $0.1 \mathrm{M}$ citrate $\mathrm{pH} 4.9,1 \mathrm{M}$ ammonium sulfate, and $0.2 \mathrm{M}$ sodium/potassium tartrate. Viable crystals were obtained when the protein solution was mixed with the reservoir solution at a 2:1 volume ratio. Crystals were cryoprotected with mother liquor plus $25 \%$ ethylene glycol prior to vitrification in liquid nitrogen.

Data Collection. Diffraction data were collected at the Diamond Light Source, station I03 using monochromatic radiation at a wavelength of $0.9686 \AA$.

Phasing, Model Building, Refinement, and Validation. Data were processed with Xia2 and subsequently scaled using the program AIMLESS from the CCP4 suite. ${ }^{64,65}$ Initial phases were obtained by molecular replacement using the program PHASER and the structure of ALK2 (Protein Data Bank code 6SZM) as a search model. ${ }^{66}$ The resulting structure solution was refined using Phenix Refine and manually rebuilt with COOT. ${ }^{67,68}$ The complete structure was verified for geometric correctness with MolProbity. ${ }^{69}$ Data collection and refinement statistics can be found in the Supporting Information, Table S3. Cocrystal images in the article were processed using Molsoft MolBrowser 3.8, and the 2D ligand interaction plot was generated using Maestro (Schrödinger Release 2019-4, Schrödinger, LLC, New York).

\section{ASSOCIATED CONTENT}

\section{(s) Supporting Information}

The Supporting Information is available free of charge at https://pubs.acs.org/doi/10.1021/acs.jmedchem.0c01199.

Kinase selectivity panel, safety screen panel, ALK2. M4K2009 cocrystal data collection and refinement statistics, ${ }^{1} \mathrm{H}$ spectra and HPLC traces of select compounds (PDF)

Molecular formula strings (CSV) 


\section{Accession Codes}

PBD ID codes: ALK2·M4K2009, 6SZM; ALK2·LDN-213844, 4BGG.

\section{AUTHOR INFORMATION}

\section{Corresponding Authors}

David Smil - Drug Discovery Program, Ontario Institute for Cancer Research, 661 University Avenue, Toronto, Ontario M5G 0A3, Canada; 10 orcid.org/0000-0002-6232-6087; Phone: +1 (647) 260-6454; Email: david.smil@oicr.on.ca

Methvin B. Isaac - Drug Discovery Program, Ontario Institute for Cancer Research, 661 University Avenue, Toronto, Ontario M5G 0A3, Canada; Phone: +1 (416) 673-6655;

Email: methvin.isaac@oicr.on.ca

\section{Authors}

Jong Fu Wong - Structural Genomics Consortium, University of Oxford, Oxford OX3 7DQ, United Kingdom

Eleanor P. Williams - Structural Genomics Consortium, University of Oxford, Oxford OX3 7DQ, United Kingdom

Roslin J. Adamson - Structural Genomics Consortium, University of Oxford, Oxford OX3 7DQ, United Kingdom

Alison Howarth - Structural Genomics Consortium, University of Oxford, Oxford OX3 7DQ, United Kingdom

David A. McLeod - Drug Discovery Program, Ontario Institute for Cancer Research, 661 University Avenue, Toronto, Ontario M5G 0A3, Canada

Ahmed Mamai - Drug Discovery Program, Ontario Institute for Cancer Research, 661 University Avenue, Toronto, Ontario M5G OA3, Canada

Soyoung Kim - Drug Discovery Program, Ontario Institute for Cancer Research, 661 University Avenue, Toronto, Ontario M5G OA3, Canada

Brian J. Wilson - Drug Discovery Program, Ontario Institute for Cancer Research, 661 University Avenue, Toronto, Ontario M5G OA3, Canada

Taira Kiyota - Drug Discovery Program, Ontario Institute for Cancer Research, 661 University Avenue, Toronto, Ontario M5G OA3, Canada

Ahmed Aman - Drug Discovery Program, Ontario Institute for Cancer Research, 661 University Avenue, Toronto, Ontario M5G 0A3, Canada; Leslie Dan Faculty of Pharmacy, University of Toronto, Toronto, Ontario M5S 3M2, Canada

Julie Owen - Drug Discovery Program, Ontario Institute for Cancer Research, 661 University Avenue, Toronto, Ontario M5G OA3, Canada

Gennady Poda - Drug Discovery Program, Ontario Institute for Cancer Research, 661 University Avenue, Toronto, Ontario M5G 0A3, Canada; Leslie Dan Faculty of Pharmacy, University of Toronto, Toronto, Ontario M5S 3M2, Canada

Kurumi Y. Horiuchi - Reaction Biology Corp., Malvern, Pennsylvania 19355, United States

Ekaterina Kuznetsova - Reaction Biology Corp., Malvern, Pennsylvania 19355, United States

Haiching Ma - Reaction Biology Corp., Malvern, Pennsylvania 19355, United States

J. Nicole Hamblin - Charles River Discovery, Essex CB10 1XL, United Kingdom

Sue Cramp - Charles River Discovery, Essex CM19 5TR, United Kingdom

Owen G. Roberts - M4K Pharma, Toronto, Ontario M5G 1L7, Canada
Aled M. Edwards - M4K Pharma, Toronto, Ontario M5G 1L7, Canada; Structural Genomics Consortium, University of Toronto, Toronto, Ontario M5G 1L7, Canada; 다이.org/ 0000-0002-4782-6016

David Uehling - Drug Discovery Program, Ontario Institute for Cancer Research, 661 University Avenue, Toronto, Ontario M5G OA3, Canada

Rima Al-awar - Drug Discovery Program, Ontario Institute for Cancer Research, 661 University Avenue, Toronto, Ontario M5G OA3, Canada; Department of Pharmacology and Toxicology, University of Toronto, Toronto, Ontario M5S 1A8, Canada; (i) orcid.org/0000-0002-4185-055X

Alex N. Bullock - Structural Genomics Consortium, University of Oxford, Oxford OX3 7DQ, United Kingdom; (1) orcid.org/ 0000-0001-6757-0436

Jeff A. O’Meara - Drug Discovery Program, Ontario Institute for Cancer Research, 661 University Avenue, Toronto, Ontario M5G OA3, Canada; M4K Pharma, Toronto, Ontario M5G 1L7, Canada

Complete contact information is available at:

https://pubs.acs.org/10.1021/acs.jmedchem.0c01199

\section{Author Contributions}

Compounds were designed and their syntheses were devised by D.S., D.A.M., and B.J.W. Compounds were synthesized by D.S., D.A.M., and S.K. In vitro kinase screening data was generated by K.Y.H., E.K., and H.M. NanoBRET and DLA data were generated by J.F.W. and A.H. Crystallography experiments were performed by E.P.W. and R.J.A. Caco-2, microsomal stability, and PPB studies were conducted by T.K. HRMS data were generated by T.K. J.O. created the cocrystal structure graphics. G.P. generated the Oracle database where compound data were stored. A.M., A.A., J.N.H, S.C., D.U., R.A.-a., A.N.B., J.A.O., and M.B.I. were involved in experimental design, interpretation of data, and monitored project progress. O.G.R. and A.M.E. initiated the project, monitored project progress, and edited the paper. The manuscript was written by D.S. and revised by A.M.E., R.A.-a., A.N.B., and M.B.I.

\section{Notes}

The authors declare no competing financial interest.

The authors will release the atomic coordinates and experimental data upon article publication.

\section{ACKNOWLEDGMENTS}

M4K Pharma Inc., functioning as a virtual biotech, serves as a de facto hub for gathering and aligning the cooperation and contributions of academic and industry partners into a drug development program that operates free of restrictions on data disclosure (i.e., no patents are filed). Work was performed by nonprofit organizations, the Ontario Institute for Cancer Research (OICR), and the Structural Genomics Consortium (SGC), with additional biological evaluation of compounds made possible through the in-kind contributions of collaborators at Reaction Biology Corporation and Charles River Laboratories. This work was funded by the Cancer Therapeutics Innovation Pipeline program at the OICR, which receives financial support from the Government of Ontario through the Ministry of Training, Colleges, and Universities. Funding from The Brain Tumour Charity was used to support the cellular and crystallographic research conducted at the University of Oxford. The SGC is a registered charity (number 1097737) that receives funds from AbbVie, Bayer Pharma AG, Boehringer Ingelheim, 
Canada Foundation for Innovation, Eshelman Institute for Innovation, Genome Canada through the Ontario Genomics Institute [OGI-055], Innovative Medicines Initiative (EU/ EFPIA) [ULTRA-DD grant no. 115766], Janssen, Merck KGaA, Darmstadt, Germany, MSD, Novartis Pharma AG, Pfizer, São Paulo Research Foundation-FAPESP, Takeda, and Wellcome [106169/ZZ14/Z]. The authors thank the Reaction Biology Corporation kinase assay group for their pro bono contribution to the in vitro kinase screening and Charles River Laboratories Cleveland for all hERG activity screening. The authors also thank Mehakpreet Saini for contributing to the writing and editing of ADME protocols.

\section{ABBREVIATIONS}

ALK2, activin receptor-like kinase-2; BMP, bone morphogenetic protein; $B / P$, total brain-to-plasma ratio; BRET, bioluminescence resonance energy transfer; $\mathrm{BTB}$, brain tissue binding; $C_{\max }$ maximum concentration; DIPG, diffuse intrinsic pontine glioma; DLA, dual luciferase assay; EDG, electron donating group; EWG, electron withdrawing group; FOP, fibrodysplasia ossificans progressiva; GS, glycine-serine; HLM, human liver microsome; MLM, mouse liver microsome; TGF $\beta$, transforming growth factor $\beta$

\section{REFERENCES}

(1) Girardi, F.; Allemani, C.; Coleman, M. P. Worldwide trends in survival from common childhood brain tumors: a systematic review. J. Global Oncol. 2019, 5, 1-25.

(2) Pacifici, M.; Shore, E. M. Common mutations in ALK2/ACVR1, a multi-faceted receptor, have roles in distinct pediatric musculoskeletal and neural orphan disorders. Cytokine Growth Factor Rev. 2016, 27, $93-$ 104.

(3) Taylor, K. R.; Mackay, A.; Truffaux, N.; Butterfield, Y. S.; Morozova, O.; Philippe, C.; Castel, D.; Grasso, C. S.; Vinci, M.; Carvalho, D.; Carcaboso, A. M.; de Torres, C.; Cruz, O.; Mora, J.; EntzWerle, N.; Ingram, W. J.; Monje, M.; Hargrave, D.; Bullock, A. N.; Puget, S.; Yip, S.; Jones, C.; Grill, J. Recurrent activating ACVR1 mutations in diffuse intrinsic pontine glioma. Nat. Genet. 2014, 46, 457-461.

(4) Mathew, R. K.; Rutka, J. T. Diffuse intrinsic pontine glioma: clinical features, molecular genetics, and novel targeted therapeutics. $J$. Korean Neurosurg. Soc. 2018, 61, 343-351.

(5) Hoffman, L. M.; Veldhuijzen van Zanten, S. E. M.; Colditz, N.; Baugh, J.; Chaney, B.; Hoffmann, M.; Lane, A.; Fuller, C.; Miles, L.; Hawkins, C.; Bartels, U.; Bouffet, E.; Goldman, S.; Leary, S.; Foreman, N. K.; Packer, R.; Warren, K. E.; Broniscer, A.; Kieran, M. W.; Minturn, J.; Comito, M.; Broxson, E.; Shih, C. S.; Khatua, S.; Chintagumpala, M.; Carret, A. S.; Escorza, N. Y.; Hassall, T.; Ziegler, D. S.; Gottardo, N.; Dholaria, H.; Doughman, R.; Benesch, M.; Drissi, R.; Nazarian, J.; Jabado, N.; Boddaert, N.; Varlet, P.; Giraud, G.; Castel, D.; Puget, S.; Jones, C.; Hulleman, E.; Modena, P.; Giagnacovo, M.; Antonelli, M.; Pietsch, T.; Gielen, G. H.; Jones, D. T. W.; Sturm, D.; Pfister, S. M.; Gerber, N. U.; Grotzer, M. A.; Pfaff, E.; von Bueren, A. O.; Hargrave, D.; Solanki, G. A.; Jadrijevic Cvrlje, F.; Kaspers, G. J. L.; Vandertop, W. P.; Grill, J.; Bailey, S.; Biassoni, V.; Massimino, M.; Calmon, R.; Sanchez, E.; Bison, B.; Warmuth-Metz, M.; Leach, J.; Jones, B.; van Vuurden, D. G.; Kramm, C. M.; Fouladi, M. Clinical, radiologic, pathologic, and molecular characteristics of long-term survivors of diffuse intrinsic pontine glioma (DIPG): a collaborative report from the international and european society for pediatric oncology DIPG registries. J. Clin. Oncol. 2018, 36, 1963-1972.

(6) Warren, K. E. Diffuse intrinsic pontine glioma: poised for progress. Front. Oncol. 2012, 2, 205.

(7) Janssens, G. O.; Gandola, L.; Bolle, S.; Mandeville, H.; RamosAlbiac, M.; van Beek, K.; Benghiat, H.; Hoeben, B.; Morales La Madrid, A.; Kortmann, R. D.; Hargrave, D.; Menten, J.; Pecori, E.; Biassoni, V.; von Bueren, A. O.; van Vuurden, D. G.; Massimino, M.; Sturm, D.; Peters, M.; Kramm, C. M. Survival benefit for patients with diffuse intrinsic pontine glioma (DIPG) undergoing re-irradiation at first progression: a matched-cohort analysis on behalf of the SIOP-E-HGG/ DIPG working group. Eur. J. Cancer 2017, 73, 38-47.

(8) Di, L.; Rong, H.; Feng, B. Demystifying brain penetration in central nervous system drug discovery. J. Med. Chem. 2013, 56, 2-12.

(9) Cohen, K. J.; Heideman, R. L.; Zhou, T.; Holmes, E. J.; Lavey, R. S.; Bouffet, E.; Pollack, I. F. Temozolomide in the treatment of children with newly diagnosed diffuse intrinsic pontine gliomas: a report from the Children's Oncology Group. Neuro-Oncol. 2011, 13, 410-416.

(10) Korones, D. N.; Fisher, P. G.; Kretschmar, C.; Zhou, T.; Chen, Z.; Kepner, J.; Freeman, C. Treatment of children with diffuse intrinsic brain stem glioma with radiotherapy, vincristine and oral VP-16: a children's oncology group phase II study. Pediatr. Blood Cancer 2008, 50, 227-230.

(11) Roujeau, T.; Machado, G.; Garnett, M. R.; Miquel, C.; Puget, S.; Geoerger, B.; Grill, J.; Boddaert, N.; Di Rocco, F.; Zerah, M.; SainteRose, C. Stereotactic biopsy of diffuse pontine lesions in children. J. Neurosurg. 2007, 107, 1-4.

(12) Jones, C.; Karajannis, M. A.; Jones, D. T. W.; Kieran, M. W.; Monje, M.; Baker, S. J.; Becher, O. J.; Cho, Y. J.; Gupta, N.; Hawkins, C.; Hargrave, D.; Haas-Kogan, D. A.; Jabado, N.; Li, X. N.; Mueller, S.; Nicolaides, T.; Packer, R. J.; Persson, A. I.; Phillips, J. J.; Simonds, E. F.; Stafford, J. M.; Tang, Y.; Pfister, S. M.; Weiss, W. A. Pediatric highgrade glioma: biologically and clinically in need of new thinking. NeuroOncol. 2017, 19, 153-161.

(13) Mackay, A.; Burford, A.; Carvalho, D.; Izquierdo, E.; FazalSalom, J.; Taylor, K. R.; Bjerke, L.; Clarke, M.; Vinci, M.; Nandhabalan, M.; Temelso, S.; Popov, S.; Molinari, V.; Raman, P.; Waanders, A. J.; Han, H. J.; Gupta, S.; Marshall, L.; Zacharoulis, S.; Vaidya, S.; Mandeville, H. C.; Bridges, L. R.; Martin, A. J.; Al-Sarraj, S.; Chandler, C.; Ng, H. K.; Li, X.; Mu, K.; Trabelsi, S.; Brahim, D. H.; Kisljakov, A. N.; Konovalov, D. M.; Moore, A. S.; Carcaboso, A. M.; Sunol, M.; de Torres, C.; Cruz, O.; Mora, J.; Shats, L. I.; Stavale, J. N.; Bidinotto, L. T.; Reis, R. M.; Entz-Werle, N.; Farrell, M.; Cryan, J.; Crimmins, D.; Caird, J.; Pears, J.; Monje, M.; Debily, M. A.; Castel, D.; Grill, J.; Hawkins, C.; Nikbakht, H.; Jabado, N.; Baker, S. J.; Pfister, S. M.; Jones, D. T. W.; Fouladi, M.; von Bueren, A. O.; Baudis, M.; Resnick, A.; Jones, C. Integrated molecular meta-analysis of 1,000 pediatric high-grade and diffuse intrinsic pontine glioma. Cancer Cell 2017, 32, 520-537.

(14) Jones, C.; Baker, S. J. Unique genetic and epigenetic mechanisms driving paediatric diffuse high-grade glioma. Nat. Rev. Cancer 2014, 14, 651-661.

(15) Melé, M.; Ferreira, P. G.; Reverter, F.; DeLuca, D. S.; Monlong, J.; Sammeth, M.; Young, T. R.; Goldmann, J. M.; Pervouchine, D. D.; Sullivan, T. J.; Johnson, R.; Segrè, A. V.; Djebali, S.; Niarchou, A.; The GTEx Consortium; Wright, F. A.; Lappalainen, T.; Calvo, M.; Getz, G.; Dermitzakis, E. T.; Ardlie, K. G.; Guigó, R. The human transcriptome across tissues and individuals. Science 2015, 348, 660-665.

(16) Taylor, K. R.; Vinci, M.; Bullock, A. N.; Jones, C. ACVR1 mutations in DIPG: lessons learned from FOP. Cancer Res. 2014, 74, $4565-4570$.

(17) Shore, E. M.; Xu, M.; Feldman, G. J.; Fenstermacher, D. A.; Cho, T. J.; Choi, I. H.; Connor, J. M.; Delai, P.; Glaser, D. L.; LeMerrer, M.; Morhart, R.; Rogers, J. G.; Smith, R.; Triffitt, J. T.; Urtizberea, J. A.; Zasloff, M.; Brown, M. A.; Kaplan, F. S. A recurrent mutation in the BMP type I receptor ACVR1 causes inherited and sporadic fibrodysplasia ossificans progressiva. Nat. Genet. 2006, 38, 525-527.

(18) Kaplan, F. S.; Xu, M.; Seemann, P.; Connor, J. M.; Glaser, D. L.; Carroll, L.; Delai, P.; Fastnacht-Urban, E.; Forman, S. J.; GillessenKaesbach, G.; Hoover-Fong, J.; Koster, B.; Pauli, R. M.; Reardon, W.; Zaidi, S. A.; Zasloff, M.; Morhart, R.; Mundlos, S.; Groppe, J.; Shore, E. M. Classic and atypical fibrodysplasia ossificans progressiva (FOP) phenotypes are caused by mutations in the bone morphogenetic protein (BMP) type I receptor ACVR1. Hum. Mutat. 2009, 30, 379390.

(19) Nikbakht, H.; Panditharatna, E.; Mikael, L. G.; Li, R.; Gayden, T.; Osmond, M.; Ho, C. Y.; Kambhampati, M.; Hwang, E. I.; Faury, D.; Siu, 
A.; Papillon-Cavanagh, S.; Bechet, D.; Ligon, K. L.; Ellezam, B.; Ingram, W. J.; Stinson, C.; Moore, A. S.; Warren, K. E.; Karamchandani, J.; Packer, R. J.; Jabado, N.; Majewski, J.; Nazarian, J. Spatial and temporal homogeneity of driver mutations in diffuse intrinsic pontine glioma. Nat. Commun. 2016, 7, No. 11185.

(20) ten Dijke, P.; Ichijo, H.; Franzen, P.; Schulz, P.; Saras, J.; Toyoshima, H.; Heldin, C. H.; Miyazono, K. Activin receptor-like kinases: a novel subclass of cell-surface receptors with predicted serine/ threonine kinase activity. Oncogene 1993, 8, 2879-2887.

(21) Macias-Silva, M.; Hoodless, P. A.; Tang, S. J.; Buchwald, M.; Wrana, J. L. Specific activation of Smad1 signaling pathways by the BMP7 type I receptor, ALK2. J. Biol. Chem. 1998, 273, 25628-25636. (22) López-Rovira, T.; Chalaux, E.; Massague, J.; Rosa, J. L.; Ventura, F. Direct binding of Smad1 and Smad4 to two distinct motifs mediates bone morphogenetic protein-specific transcriptional activation of Id1 gene. J. Biol. Chem. 2002, 277, 3176-3185.

(23) Korchynskyi, O.; ten Dijke, P. Identification and functional characterization of distinct critically important bone morphogenetic protein-specific response elements in the Id 1 promoter. J. Biol. Chem. 2002, 277, 4883-4891.

(24) Hino, K.; Ikeya, M.; Horigome, K.; Matsumoto, Y.; Ebise, H.; Nishio, M.; Sekiguchi, K.; Shibata, M.; Nagata, S.; Matsuda, S.; Toguchida, J. Neofunction of ACVR1 in fibrodysplasia ossificans progressiva. Proc. Natl. Acad. Sci. U.S.A. 2015, 112, 15438-15443.

(25) Hatsell, S. J.; Idone, V.; Wolken, D. M.; Huang, L.; Kim, H. J.; Wang, L.; Wen, X.; Nannuru, K. C.; Jimenez, J.; Xie, L.; Das, N.; Makhoul, G.; Chernomorsky, R.; D’Ambrosio, D.; Corpina, R. A.; Schoenherr, C. J.; Feeley, K.; Yu, P. B.; Yancopoulos, G. D.; Murphy, A. J.; Economides, A. N. ACVR1R206H receptor mutation causes fibrodysplasia ossificans progressiva by imparting responsiveness to activin A. Sci. Transl. Med. 2015, 7, No. 303ra137.

(26) Wu, G.; Diaz, A. K.; Paugh, B. S.; Rankin, S. L.; Ju, B.; Li, Y.; Zhu, X.; Qu, C.; Chen, X.; Zhang, J.; Easton, J.; Edmonson, M.; Ma, X.; Lu, C.; Nagahawatte, P.; Hedlund, E.; Rusch, M.; Pounds, S.; Lin, T.; OnarThomas, A.; Huether, R.; Kriwacki, R.; Parker, M.; Gupta, P.; Becksfort, J.; Wei, L.; Mulder, H. L.; Boggs, K.; Vadodaria, B.; Yergeau, D.; Russell, J. C.; Ochoa, K.; Fulton, R. S.; Fulton, L. L.; Jones, C.; Boop, F. A.; Broniscer, A.; Wetmore, C.; Gajjar, A.; Ding, L.; Mardis, E. R.; Wilson, R. K.; Taylor, M. R.; Downing, J. R.; Ellison, D. W.; Zhang, J.; Baker, S. $\mathrm{J}$. The genomic landscape of diffuse intrinsic pontine glioma and pediatric non-brainstem high-grade glioma. Nat. Genet. 2014, 46, 444450.

(27) Hoeman, C. M.; Cordero, F. J.; Hu, G.; Misuraca, K.; Romero, M. M.; Cardona, H. J.; Nazarian, J.; Hashizume, R.; McLendon, R.; Yu, P.; Procissi, D.; Gadd, S.; Becher, O. J. ACVR1 R206H cooperates with $\mathrm{H} 3.1 \mathrm{~K} 27 \mathrm{M}$ in promoting diffuse intrinsic pontine glioma pathogenesis. Nat. Commun. 2019, 10, No. 1023.

(28) Yu, P. B.; Hong, C. C.; Sachidanandan, C.; Babitt, J. L.; Deng, D. Y.; Hoyng, S. A.; Lin, H. Y.; Bloch, K. D.; Peterson, R. T. Dorsomorphin inhibits BMP signals required for embryogenesis and iron metabolism. Nat. Chem. Biol. 2008, 4, 33-41.

(29) Hopkins, C. R. Inhibitors of the bone morphogenetic protein (BMP) signaling pathway: a patent review (2008-2015). Expert Opin. Ther. Pat. 2016, 26, 1115-1128.

(30) Cuny, G. D.; Yu, P. B.; Laha, J. K.; Xing, X.; Liu, J.-F.; Lai, C. S.; Deng, D. Y.; Sachidanandan, C.; Bloch, K. D.; Peterson, R. T. Structureactivity relationship study of bone morphogenetic protein (BMP) signaling inhibitors. Bioorg. Med. Chem. Lett. 2008, 18, 4388-4392.

(31) Mohedas, A. H.; Xing, X.; Armstrong, K. A.; Bullock, A. N.; Cuny, G. D.; Yu, P. B. Development of an ALK2-biased BMP type I receptor kinase inhibitor. ACS Chem. Biol. 2013, 8, 1291-1302.

(32) Williams, E.; Bullock, A. N. Structural basis for the potent and selective binding of LDN-212854 to the BMP rceptor kinase ALK2. Bone 2018, 109, 251-258.

(33) Yu, P. B.; Deng, D. Y.; Lai, C. S.; Hong, C. C.; Cuny, G. D.; Bouxsein, M. L.; Hong, D. W.; McManus, P. M.; Katagiri, T.; Sachidanandan, C.; Kamiya, N.; Fukuda, T.; Mishina, Y.; Peterson, R. T.; Bloch, K. D. BMP type I receptor inhibition reduces heterotopic [corrected] ossification. Nat. Med. 2008, 14, 1363-1369.
(34) Vogt, J.; Traynor, R.; Sapkota, G. P. The specificities of small molecule inhibitors of the TGF $\beta$ and BMP pathways. Cell. Signalling 2011, 23, 1831-1842.

(35) Sinha, S.; Mundy, C.; Bechtold, T.; Sgariglia, F.; Ibrahim, M. M.; Billings, P. C.; Carroll, K.; Koyama, E.; Jones, K. B.; Pacific, M. Unsuspected osteochondroma-like outgrowths in the crania base of hereditary multiple exostoses patients and modeling and treatment with a BMP antagonist in mice. PloS Genet. 2017, 13, No. e1006742.

(36) Sanvitale, C. E.; Kerr, G.; Chaikuad, A.; Ramel, M. C.; Mohedas, A. H.; Reichert, S.; Wang, Y.; Triffitt, J. T.; Cuny, G. D.; Yu, P. B.; Hill, C. S.; Bullock, A. N. A new class of small molecule inhibitor of BMP signaling. PLoS One 2013, 8, No. e62721.

(37) Mohedas, A. H.; Wang, Y.; Sanvitale, C. E.; Canning, P.; Choi, S.; Xing, X.; Bullock, A. N.; Cuny, G. D.; Yu, P. B. Structure-activity relationship of 3,5-diaryl-2-aminopyridine ALK2 inhibitors reveals unaltered binding affinity for fibrodysplasia ossificans progressiva causing mutants. J. Med. Chem. 2014, 57, 7900-7915.

(38) Jiang, J.-k.; Huang, X.; Shamim, K.; Patel, P. R.; Lee, A.; Wang, A. Q.; Nguyen, K.; Tawa, G.; Cuny, G. D.; Yu, P. B.; Zheng, W.; Xu, X.; Sanderson, P.; Huang, W. Discovery of 3-(4-sulfamoylnaphthyl)pyrazolo[1,5-a]pyrimidines as potent and selective ALK2 inhibitors. Bioorg. Med. Chem. Lett. 2018, 28, 3356-3362.

(39) Hudson, L.; Mui, J.; Vazquez, S.; Carvalho, D. M.; Williams, E.; Jones, C.; Bullock, A. N.; Hoelder, S. Novel quinazolinone inhibitors of ALK2 flip between alternate binding modes: structure-activity relationship, structural characterization, kinase profiling, and cellular proof of concept. J. Med. Chem. 2018, 61, 7261-7272.

(40) Sekimata, K.; Sato, T.; Sakai, N.; Watanabe, H.; MishimaTsumagari, C.; Taguri, T.; Matsumoto, T.; Fujii, Y.; Handa, N.; Honma, T.; Tanaka, A.; Shirouzu, M.; Yokoyama, S.; Miyazono, K.; Hashizume, Y.; Koyama, H. Bis-heteroaryl pyrazoles: identification of orally bioavailable inhibitors of activin receptor-like kinase-2 (R206H). Chem. Pharm. Bull. (Tokyo) 2019, 67, 224-235.

(41) Sánchez-Duffhues, G.; Williams, E.; Benderitter, P.; Orlova, V.; van Wijhe, M.; Garcia de Vinuesa, A.; Kerr, G.; Caradec, J.; Lodder, K.; de Boer, H. C.; Goumans, M.-J.; Eekhoff, E. M. W.; Morales-Piga, A.; Bachiller-Corral, J.; Koolwijk, P.; Bullock, A. N.; Hoflack, J.; ten Dijke, P. Development of macrocycle kinase inhibitors for ALK2 using fibrodysplasia ossificans progressiva-derived endothelial cells. JBMR Plus 2019, 3, No. e10230.

(42) Wentworth, K. L.; Masharani, U.; Hsiao, E. C. Therapeutic advances for blocking heterotopic ossification in fibrodysplasia ossificans progressiva. Br. J. Clin. Pharmacol. 2019, 85, 1180-1187.

(43) Carvalho, D.; Taylor, K. R.; Olaciregui, N. G.; Molinari, V.; Clarke, M.; Mackay, A.; Ruddle, R.; Henley, A.; Valenti, M.; Hayes, A.; Brandon, A. H.; Eccles, S. A.; Raynaud, F.; Boudhar, A.; Monje, M.; Popov, S.; Moore, A. S.; Mora, J.; Cruz, O.; Vinci, M.; Brennan, P. E.; Bullock, A. N.; Carcaboso, A. M.; Jones, C. ALK2 inhibitors display beneficial effects in preclinical models of ACVR1 mutant diffuse intrinsic pontine glioma. Commun. Biol. 2019, 2, No. 156.

(44) Morgan, M. R.; Roberts, O. G.; Edwards, A. M. Ideation and implementation of an open science drug discovery business model M4K Pharma. Wellcome Open Res. 2018, 3, 154.

(45) Wong, J. F.; Brown, E. J.; Williams, E.; Bullock, A. N. Fostering open collaboration in drug development for paediatric brain tumours. Biochem. Soc. Trans. 2019, 47, 1471-1479.

(46) Herbertz, S.; Sawyer, J. S.; Stauber, A. J.; Gueorguieva, I.; Driscoll, K. E.; Estrem, S. T.; Cleverly, A. L.; Desaiah, D.; Guba, S. C.; Benhadji, K. A.; Slapak, C. A.; Lahn, M. M. Clinical development of galunisertib (LY2157299 monohydrate), a small molecule inhibitor of transforming growth factor-beta signaling pathway. Drug Des., Dev. Ther. 2015, 9, 4479-4499.

(47) Pasteuning-Vuhman, S.; Boertje-van der Meulen, J. W.; van Putten, M.; Overzier, M.; ten Dijke, P.; Kiełbasa, S. M.; Arindrarto, W.; Wolterbeek, R.; Lezhnina, K. V.; Ozerov, I. V.; Aliper, A. M.; Hoogaars, W. M.; Aartsma-Rus, A.; Loomans, C. J. M. New function of the myostatin/activin type I receptor (ALK4) as a mediator of muscle atrophy and muscle regeneration. FASEB J. 2017, 31, 238-255. 
(48) Roman, B. L.; Hinck, A. P. ALK1 signaling in development and disease: new paradigms. Cell. Mol. Life Sci. 2017, 74, 4539-4560.

(49) Steinbicker, A. U.; Bartnikas, T. B.; Lohmeyer, L. K.; Leyton, P.; Mayeur, C.; Kao, S. M.; Pappas, A. E.; Peterson, R. T.; Bloch, D. B.; Yu, P. B.; Fleming, M. D.; Bloch, K. D. Perturbation of hepcidin expression by BMP type I receptor deletion induces iron overload in mice. Blood 2011, 118, 4224-4230.

(50) Goff, L. W.; Cohen, R. B.; Berlin, J. D.; de Braud, F. G.; Lyshchik, A.; Noberasco, C.; Bertolini, F.; Carpentieri, M.; Stampino, C. G.; Abbattista, A.; Wang, E.; Borghaei, H. A Phase I study of the anti-activin receptor-like kinase 1 (ALK-1) monoclonal antibody PF-03446962 in patients with advanced solid tumors. Clin. Cancer Res. 2016, 22, 21462154.

(51) Pajouhesh, H.; Lenz, G. R. Medicinal chemistry properties of successful central nervous system drugs. NeuroRx 2005, 2, 541-553.

(52) Rankovic, Z. CNS drug design: balancing physicochemical properties for optimal brain exposure. J. Med. Chem. 2015, 58, 25842608.

(53) Heffron, T. P. Small molecule kinase inhibitors for the treatment of brain cancer. J. Med. Chem. 2016, 59, 10030-10066.

(54) Sanguinetti, M. C.; Tristani-Firouzi, M. hERG potassium channels and cardiac arrhythmia. Nature 2006, 440, 463-469.

(55) Shah, R. R.; Morganroth, J.; Shah, D. R. Cardiovascular safety of tyrosine kinase inhibitors: with a special focus on cardiac repolarisation (QT interval). Drug Saf. 2013, 36, 295-316.

(56) Smil, D.; McLeod, D. A.; O’Meara, J. A.; Isaac, M. B. Unpublished results. Data can be viewed in presentations archived at https://m4kpharma.com/blog/ (accessed Jul 10, 2020).

(57) Ensan, D.; Smil, D.; Zepeda-Velázquez, C. A.; Panagopoulos, D.; Wong, J. F.; Williams, E. P.; Adamson, R.; Bullock, A. N.; Kiyota, T.; Aman, A.; Roberts, O. G.; Edwards, A. M.; O’Meara, J. A.; Isaac, M. B.; Al-awar, R. Targeting ALK2: an open science approach to developing therapeutics for the treatment of diffuse intrinsic pontine glioma. J. Med. Chem. 2020, 63, 4978-4996.

(58) Predicted cLogP, pKa, and tPSA values were calculated using ChemDraw Professional 17.1.

(59) Cavalli, A.; Poluzzi, E.; De Ponti, F.; Recanatini, M. Toward a pharmacophore for drugs inducing the long QT syndrome: insights from a CoMFA study of HERG K+ channel blockers. J. Med. Chem. 2002, 45, 3844-3853.

(60) Jamieson, C.; Moir, E. M.; Rankovic, Z.; Wishart, G. Medicinal chemistry of hERG optimizations: highlights and hang-ups. J. Med. Chem. 2006, 49, 5029-5046.

(61) Morgenthaler, M.; Schweizer, E.; Hoffmann-Röder, A.; Benini, F.; Martin, R. E.; Jaeschke, G.; Wagner, B.; Fischer, H.; Bendels, S.; Zimmerli, D.; Schneider, J.; Diederich, F.; Kansy, M.; Müller, K. Predicting and tuning physicochemical properties in lead optimization: amine basicities. ChemMedChem 2007, 2, 1100-1115.

(62) Liu, X.; Wright, M.; Hop, C. E. C. A. Rational use of plasma protein and tissue binding data in drug design. J. Med. Chem. 2014, 57, $8238-8248$.

(63) Chakkalakal, S. A.; Shore, E. M. Heterotopic Ossification in Mouse Models of Fibrodysplasia Ossificans Progressiva. In Bone Morphogenetic Proteins: Methods and Protocols (Methods in Molecular Biology); Rogers, M. B., Ed.; Springer Nature: Berlin, 2019; Vol. 1891, pp 247-255.

(64) Winter, G. xia2: an expert system for macromolecular crystallography data reduction. J. Appl. Crystallogr. 2010, 43, 186-190.

(65) Winn, M. D.; Ballard, C. C.; Cowtan, K. D.; Dodson, E. J.; Emsley, P.; Evans, P. R.; Keegan, R. M.; Krissinel, E. B.; Leslie, A. G. W.; McCoy, A.; McNicholas, S. J.; Murshudov, G. N.; Pannu, N. S.; Potterton, E. A.; Powell, H. R.; Read, R. J.; Vagin, A.; Wilson, K. S. Overview of the CCP4 suite and current developments. Acta Crystallogr., Sect. D: Biol. Crystallogr. 2011, 67, 235-242.

(66) McCoy, A. J.; Grosse-Kunstleve, R. W.; Adams, P. D.; Winn, M. D.; Storoni, L. C.; Read, R. J. Phaser crystallographic software. J. Appl. Crystallogr. 2007, 40, 658-674.

(67) Adams, P. D.; Afonine, P. V.; Bunkóczi, G.; Chen, V. B.; Davis, I. W.; Echols, N.; Headd, J. J.; Hung, L.-W.; Kapral, G. J.; Grosse-
Kunstleve, R. W.; McCoy, A. J.; Moriarty, N. W.; Oeffner, R.; Read, R. J.; Richardson, D. C.; Richardson, J. S.; Terwilliger, T. C.; Zwart, P. H. PHENIX: a comprehensive Python-based system for macromolecular structure solution. Acta Crystallogr., Sect. D: Biol. Crystallogr. 2010, 66, 213-221.

(68) Emsley, P.; Cowtan, K. Coot: model-building tools for molecular graphics. Acta Crystallogr., Sect. D: Biol. Crystallogr. 2004, 60, 21262132.

(69) Davis, I. W.; Leaver-Fay, A.; Chen, V. B.; Block, J. N.; Kapral, G. J.; Wang, X.; Murray, L. W.; Arendall, W. B.; Snoeyink, J.; Richardson, J. S.; Richardson, D. C. MolProbity: all-atom contacts and structure validation for proteins and nucleic acids. Nucleic Acids Res. 2007, 35, W375-W383. 